
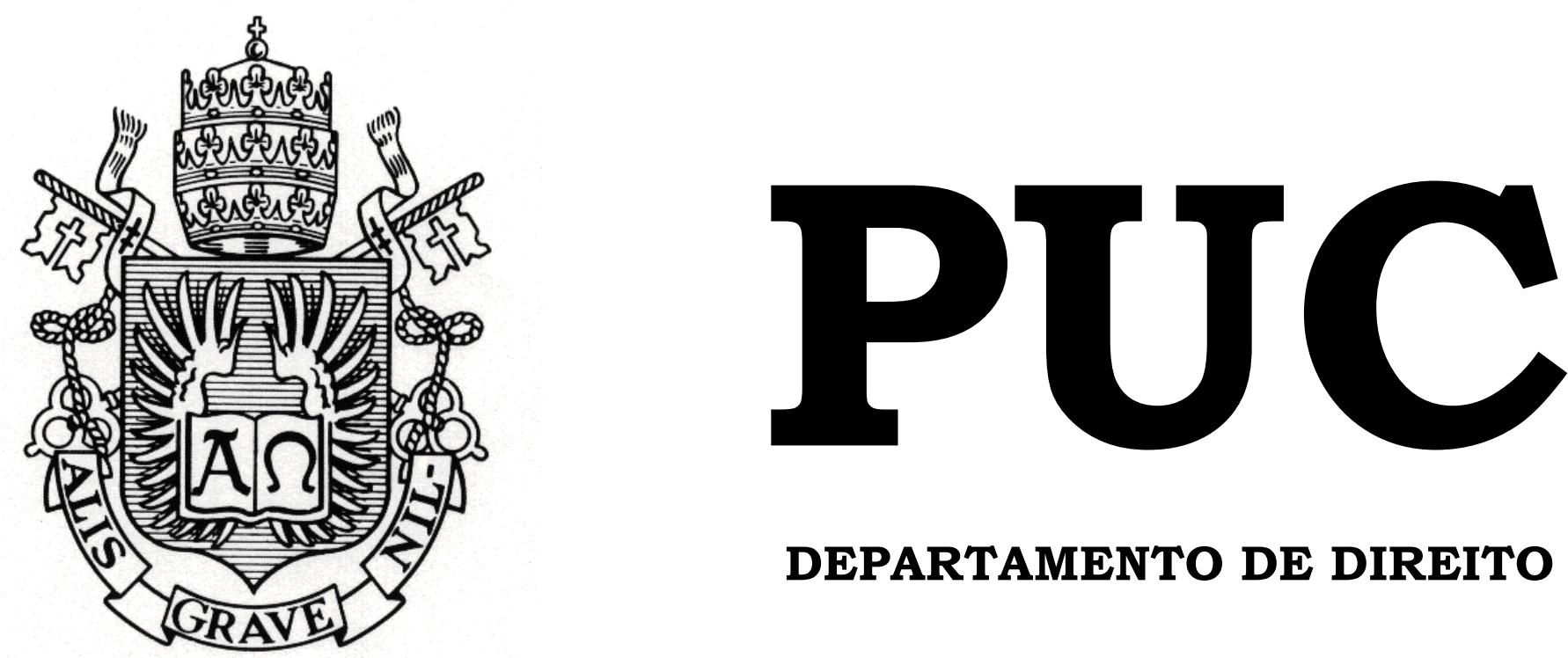

DEPARTAMENTO DE DIREITO

O CÓDIGO FLORESTAL DE 2012 NO SUPREMO TRIBUNAL FEDERAL E OS PRINCÍPIOS NORTEADORES DO DIREITO AMBIENTAL

por

RICARDO VELLOSO ARRAES

ORIENTADOR: FERNANDO CAVALCANTI WALCACER 2018.1

PONTIFÍCIA UNIVERSIDADE CATÓLICA DO RIO DE JANEIRO RUA MARQUÊS DE SÃO VICENTE, 225 - CEP 22453-900 RIO DE JANEIRO - BRASIL 


\title{
O CÓDIGO FLORESTAL DE 2012 NO SUPREMO TRIBUNAL FEDERAL E OS PRINCÍPIOS NORTEADORES DO DIREITO AMBIENTAL
}

\author{
por \\ RICARDO VELLOSO ARRAES
}

Monografia

apresentada

ao

Departamento de Direito da Pontifícia Universidade Católica do Rio de Janeiro (PUC-Rio) para a obtenção do Título de Bacharel em Direito.

Orientador: Fernando Cavalcanti Walcacer 


\section{AGRADECIMENTOS}

Gostaria de agradecer profundamente a Deus e aos meus pais pela oportunidade de cursar Direito na Pontifícia Universidade Católica do Rio de Janeiro. Devo eterna gratidão pela família que tenho, um ninho de Amor, união e exemplos.

Agradeço à minha família e amigos pelos bons momentos e pela companhia, força, carinho e exemplo diante das dificuldades e difíceis decisões a serem enfrentadas na vida.

Agradeço a todos os professores que tive na vida pelo conhecimento compartilhado, indispensável para a minha formação como ser humano e bacharel em Direito.

Para o NIMA-Jur, deixo o meu especial agradecimento por ter conhecido os meus professores de Direito Ambiental, Fernando Walcacer e Danielle Moreira, e tantos outros professores e pesquisadores. Sem essa equipe maravilhosa eu não teria adquirido tantos conhecimentos sobre o direito fundamental ao meio ambiente ecologicamente equilibrado e a luta pela sua plena concretização. 


\section{RESUMO}

O presente trabalho aborda as ações diretas de inconstitucionalidade sobre o Código Florestal de 2012 (Lei 12.651/2012) no Supremo Tribunal Federal diante dos princípios norteadores do Direito Ambiental. Também é feita uma análise crítica sobre a diminuição do alcance de tais princípios e do direito ao meio ambiente ecologicamente equilibrado no julgamento conjunto das ações.

No primeiro capítulo, há um breve histórico sobre a progressiva ecologização da sociedade, seguido de um estudo sobre o direito ao meio ambiente ecologicamente equilibrado e os princípios norteadores do Direito Ambiental, com destaque para precaução, prevenção e vedação ao retrocesso socioambiental. É demonstrado como tais princípios estabelecem um caminho rumo ao constante aumento da proteção e preservação do direito ao meio ambiente ecologicamente equilibrado. $\mathrm{O}$ segundo capítulo explora o histórico do Código Florestal de 2012 e as inconstitucionalidades discutidas nas ADIs 4901, 4902, 4903, 4937 e ADC 42, com menção também a estudos da comunidade científica sobre os espaços territorialmente protegidos.

No último parágrafo, por fim, é exposto o resultado final do julgamento conjunto no Plenário do STF, que será analisado com os argumentos dos Ministros, diante dos princípios do Direito Ambiental e a Constituição Federal.

Palavras-chave: Código Florestal de 2012; Lei 12.651/2012; Supremo Tribunal Federal (STF); Julgamento; Direito Ambiental; Princípios norteadores. 


\section{SUMÁRIO}

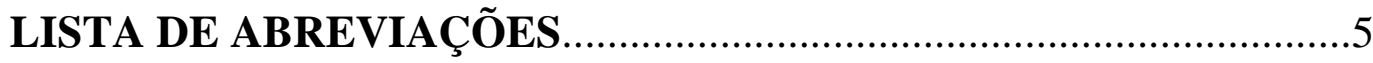

INTRODUÇÃO

1. PRINCÍPIOS NORTEADORES DO DIREITO AMBIENTAL.......8

1.1. Breve histórico da progressiva ecologização da sociedade.................8

1.2. Direito fundamental ao meio ambiente ecologicamente equilibrado 11

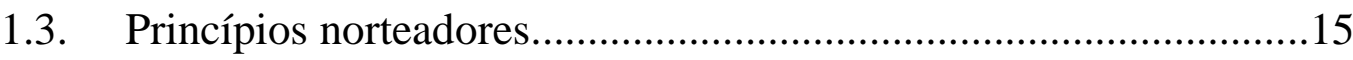

1.3.1. Princípio da precaução......................................................................16

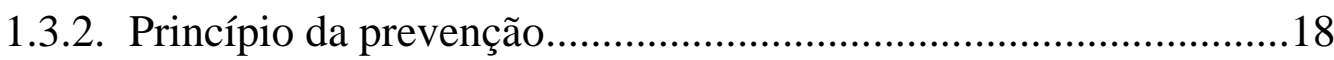

1.3.3. Princípio da vedação ao retrocesso socioambiental........................20

2. O CÓDIGO FLORESTAL DE 2012 NO SUPREMO TRIBUNAL

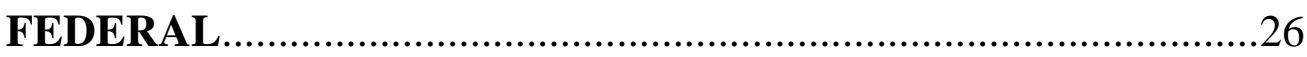

2.1. Breve histórico da Lei 12.651/2012.............................................26

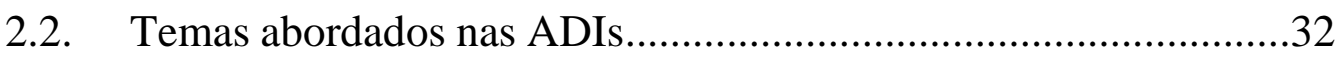

2.2.1. Anistia na esfera administrativa, criminal e civil.........................34

2.2.2. Diminuição de Áreas de Preservação Permanente (APP) e Reserva

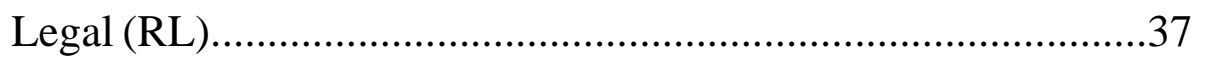

2.2.3. Pagamento por serviços ambientais e Cota de Reserva Ambiental

3. JULGAMENTO CONJUNTO NO SUPREMO TRIBUNAL

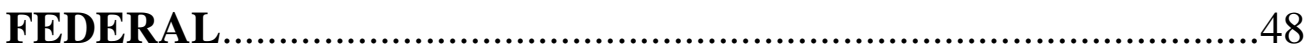

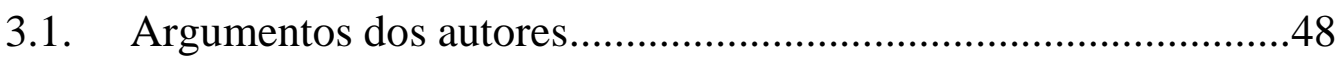

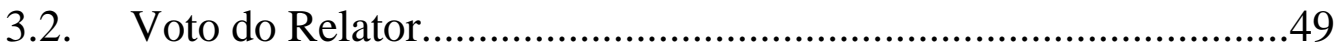

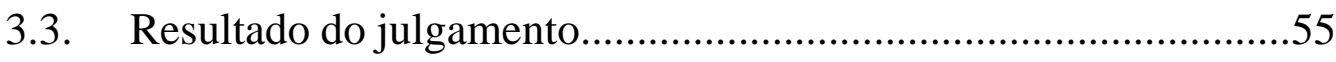

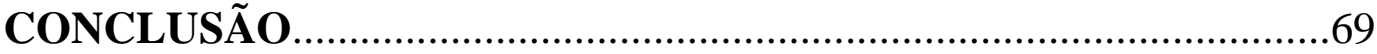

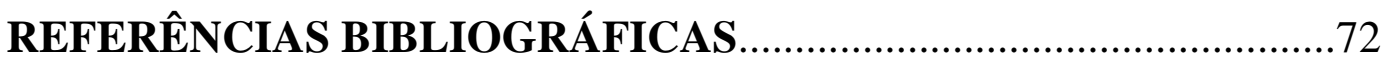




\section{LISTA DE ABREVIAÇÕES}

ADI - Ação Direta de Inconstitucionalidade

ADC - Ação Declaratória de Constitucionalidade

APP - Área de Preservação Permanente

CAR - Cadastro Ambiental Rural

CF/88 - Constituição Federal de 1988

CRA - Cota de Reserva Ambiental

IBAMA - Instituto Brasileiro do Meio Ambiente e Recursos Renováveis

ICMBio - Instituto Chico Mendes de Conservação da Biodiversidade

INPE - Instituto Nacional de Pesquisas Espaciais

MMA - Ministério do Meio Ambiente

PP - Partido Progressista

PRODES - Programa de Cálculo do Desflorestamento da Amazônia

PRA - Programa de Regularização Ambiental

PSA - Pagamento por Serviços Ambientais

PSOL - Partido Socialismo e Liberdade

RL - Reserva Legal

SBPC - Sociedade Brasileira para o Progresso da Ciência

STF - Supremo Tribunal Federal

STJ - Superior Tribunal de Justiça 


\section{INTRODUÇÃO}

No atual contexto que a sociedade brasileira vive, as diversas conquistas no campo do Direito Ambiental vêm gradativamente sofrendo tentativas de desmantelamento, frente ao crescente poder do agronegócio e empresariado no Congresso Nacional.

Um dos exemplos mais notórios e importantes dessa situação foi a sanção quase integral da Lei 12.651, de 25 de maio de 2012, o atual Código Florestal, que atacou diretamente importantes pilares do Direito Ambiental brasileiro, os quais serão analisados neste trabalho. A esperança de grande parte da sociedade foi depositada no julgamento das ações diretas de inconstitucionalidade sobre o Código Florestal de 2012 no Supremo Tribunal Federal (STF). Em fevereiro de 2018, porém, chegou-se a um resultado largamente desfavorável para o direito ao meio ambiente ecologicamente, gerando jurisprudência que pode impactar o futuro do Direito Ambiental e o entendimento acerca do alcance de seus principais princípios.

Não se pretende fazer uma exposição minuciosa do Código Florestal e dos votos dos Ministros no julgamento conjunto das ações, mas sim uma análise crítica sobre o que a recente jurisprudência pode representar para os princípios norteadores do Direito Ambiental. O presente trabalho pretende analisar como a recente decisão do STF acerca da Lei 12.651, o Código Florestal de 2012, relativiza os princípios norteadores do Direito Ambiental, mencionando também os retrocessos e impactos ambientais previsíveis possivelmente potencializados com a Lei 12.651/2012.

Desse modo, será apresentado inicialmente um breve histórico da progressiva ecologização da sociedade, que possibilitou a constitucionalização do direito fundamental ao meio ambiente ecologicamente equilibrado. O Art. 225 da Constituição Federal de 1988, cuja proteção ao meio ambiente repercute em todo o ordenamento jurídico brasileiro será abordado, junto com as obrigações do Poder Público para garantir o direito ao meio ambiente ecologicamente equilibrado. Em seguida, 
haverá menção a alguns princípios importantes para a análise do julgamento das ações sobre o Código Florestal, com ênfase nos princípios da precaução, prevenção e vedação ao retrocesso socioambiental, afrontados por uma lei que desconsidera diversos estudos científicos sobre a importância dos espaços territoriais especialmente protegidos.

A diminuição das Áreas de Preservação Permanente e Reserva Legal, a ponto de descaracterizar a proteção a elas conferida, será exemplificada no capítulo destinado aos principais pontos discutidos no Supremo Tribunal Federal, que inclui também a análise da extensa anistia instituída pelo Código Florestal de 2012 a quem desmatou anteriormente a 22 de julho de 2008.

Por fim, será mostrado o resultado final do julgamento, amplamente desfavorável à proteção ambiental, e analisados os principais argumentos dos Ministros para chegar a tal resultado, os quais prevaleceram sobre os princípios norteadores do Direito Ambiental. É importante observar que a íntegra dos votos dos Ministros ainda não foi publicada, mas é possível identificar os principais argumentos na leitura dos votos durante o julgamento no Plenário do $\mathrm{STF}^{1}$.

\footnotetext{
${ }^{1}$ O julgamento conjunto das ADIs 4901, 4902, 4903, 4937 e ADC 42 com os votos dos Ministros pode ser assistido acessando o canal oficial do STF no YouTube.
} 


\section{PRINCÍPIOS NORTEADORES DO DIREITO AMBIENTAL}

\subsection{Breve histórico da progressiva ecologização da sociedade}

Ao longo dos séculos da presença do Homo sapiens na Terra, casa comum $^{2}$ de toda a humanidade, grandes civilizações e impérios surgiram e pereceram, deixando marcas e cicatrizes no planeta. Os impactos ambientais existem desde a pré-história, notavelmente pelo papel do Homem na extinção de espécies de grandes animais que habitavam o globo terrestre.

Porém, a partir do século XVIII, os impactos ambientais aumentaram consideravelmente. Com grandes reservas de ferro, carvão e riquezas, além de uma posição geográfica estratégica e poderosa marinha, a Inglaterra iniciou a I Revolução Industrial, que mudou radicalmente a sociedade ocidental. Entre o século XIX e a primeira metade do século XX, tal processo sofre inovações, com a utilização do petróleo como principal matéria prima e a aplicação da eletricidade no processo produtivo. Agora já na II Revolução Industrial, o mundo aos poucos copiava o modelo inglês, lançando toneladas de poluentes na atmosfera terrestre, incluindo grandes quantidades de carbono oriundas dos combustíveis fósseis, "dormentes" há milhares de ano nas profundezas da Terra.

Até considerável fração do século $\mathrm{XX}$, havia a crença de que os recursos naturais e a própria natureza existiam para satisfazer os desejos e ambições humanas. Seus segredos, de acordo Francis Bacon, deveriam ser extraídos inclusive sob tortura, visto que ela não passaria de uma escrava. Entretanto, os desejos humanos são infinitos, os recursos naturais não.

\footnotetext{
${ }^{2}$ Expressão utilizada na Encíclica Laudato Si (Louvado Sejas), de autoria do Papa Francisco, que versa sobre a relação do homem com o meio ambiente: FRANCISCO I. Laudato Si: Carta Encíclica sobre o cuidado da casa comum. Disponível em $<$ http://w2.vatican.va/content/francesco/pt/encyclicals/documents/papafrancesco_20150524_enciclica-laudato-si.html> Acesso em 2 jun. 2018
} 
Conforme Maria Alexandra Aragão, o avanço técnico e cientifico, com a simultânea passagem para uma economia de mercado, "representaram um salto qualitativo nos meios ao dispor do Homem para controlar e utilizar economicamente os recursos naturais" ${ }^{3}$. A partir de, aproximadamente, a metade do século XX, a alarmante poluição havia se tornado uma ameaça séria para a Economia, gerando inclusive distorções de mercado ${ }^{4}$. Os acidentes ecológicos também se tornam mais frequentes, mudando a forma do Homem de se relacionar com a Natureza. ${ }^{5}$ Finalmente, após muitos séculos, retorna a ideia das duas partes como interdependentes entre si, do ser humano como parte da Natureza, dependente dela.

É notório ${ }^{6}$ como os seres humanos vêm causando significativos impactos e rapidamente modificando os diversos ecossistemas do globo terrestre, principalmente após a I Revolução Industrial. Diante de tal situação, o célebre químico holandês Paul Crutzen, ganhador do prêmio Nobel em 1995 pelo seu trabalho sobre a camada de ozônio, cria o conceito de "antropoceno"7. Para muitos cientistas, a Terra já teria deixado o holoceno e inaugurado uma nova época geológica, profundamente marcada pela

\footnotetext{
3 ARAGÃO, Maria Alexandra. O princípio do poluidor-pagador: pedra angular da política comunitária do ambiente. São Paulo: Inst. O Direito por um Planeta Verde, 2014. p. 19

${ }^{4}$ ARAGÃO, Maria Alexandra. O princípio do poluidor-pagador. p. 45 ,

${ }^{5}$ ARAGÃO, Maria Alexandra. O princípio do poluidor-pagador. p. 19 - 22.

6 Evidências do Antropoceno são listadas em artigo do "The Guardian". "Human activity has: Pushed extinction rates of animals and plants far above the long-term average. The Earth is on course to see $75 \%$ of species become extinct in the next few centuries if current trends continue; Increased levels of climate-warming $\mathrm{CO} 2$ in the atmosphere at the fastest rate for $66 \mathrm{~m}$ years, with fossil-fuel burning pushing levels from 280 parts per million before the industrial revolution to $400 \mathrm{ppm}$ and rising today; Put so much plastic in our waterways and oceans that microplastic particles are now virtually ubiquitous, and plastics will likely leave identifiable fossil records for future generations to discover; Doubled the nitrogen and phosphorous in our soils in the past century with fertiliser use. This is likely to be the largest impact on the nitrogen cycle in $2.5 \mathrm{bn}$ years; Left a permanent layer of airborne particulates in sediment and glacial ice such as black carbon from fossil fuel burning." CARRINGTON, Damian. The Anthropocene epoch: scientists declare dawn of human-influenced age. Disponível em <https://www.theguardian.com/environment/2016/aug/29/declareanthropocene-epoch-experts-urge-geological-congress-human-impact-earth>. Acesso em 2 jun. 2018.

${ }^{7}$ CARRINGTON, Damian. The Anthropocene epoch: scientists declare dawn of human-influenced age. Disponível em <https://www.theguardian.com/environment/2016/aug/29/declareanthropocene-epoch-experts-urge-geological-congress-human-impact-earth> Acesso em 2 jun. 2018. 2 jun. 2018.
} 
atividade humana e seus impactos no planeta. Não há um único ecossistema que não seja afetado, direta ou indiretamente, pelo ser humano ${ }^{8}$.

Tendo em vista essa situação, grande parte da problemática global do Meio Ambiente gira em torno da sustentabilidade ${ }^{9}$. Tal conceito pode ser visto de diferentes óticas. De acordo com Édis Milaré, existem duas precondições para o desenvolvimento da sustentabilidade: a primeira seria a capacidade natural de suporte, que compreenderia "os ecossistemas, biomas e todos os tipos de recursos naturais existentes nas comunidades e sociedade, objeto das ações de empreendedorismo social. "A segunda seria a capacidade de sustentação, ou seja, "atividades sociais, políticas e econômicas geradas pela própria sociedade em seu benefício próprio" ${ }^{10}$.

A questão ambiental passa gradativamente a ser debatida por todo o mundo ao longo do século XX. Em 1972 há o marco temporal para o renascimento da Ecologia com a Conferência das Nações Unidas sobre o Meio Ambiente Humano, em Estocolmo.

Os princípios da Conferencia de Estocolmo tratam da questão do desenvolvimento ligado ao meio ambiente ${ }^{11}$, mas é no Relatório de Brundtland (1987), da ONU, que se utiliza a expressão “desenvolvimento sustentável" como

um processo de transformação no qual a exploração dos recursos, a direção dos investimentos, a orientação do desenvolvimento tecnológico e a mudança institucional se harmonizam e reforçam o potencial presente e futuro, a fim de atender às necessidades e aspirações humanas. ${ }^{12}$

O Direito não pode escapar da interdisciplinaridade e da prática em um universo mais amplo ${ }^{13}$ e complexo. Desse modo, torna-se um importante

\footnotetext{
${ }^{8}$ CARRINGTON, Damian. The Anthropocene epoch: scientists declare dawn of human-influenced age. Disponível em <https://www.theguardian.com/environment/2016/aug/29/declareanthropocene-epoch-experts-urge-geological-congress-human-impact-earth> Acesso em 2 jun. 2018. 2 jun. 2018

${ }^{9}$ MILARÉ, Édis. Direito do Ambiente. $8^{\text {a }}$ ed.. São Paulo: Revista dos Tribunais, 2013. p. 45.

${ }^{10}$ MILARÉ, Édis. Direito do Ambiente. p. 68 e 69.

${ }^{11}$ MACHADO, Paulo Affonso Leme. Direito Ambiental Brasileiro. $22^{\mathrm{a}}$ ed.. São Paulo: Malheiros, 2014. p. 72.

12 Disponível em <http://www.senado.gov.br/noticias/Jornal/emdiscussao/rio20/temas-emdiscussao-na-rio20/ecodesenvolvimento-conceito-desenvolvimento-sustentavel-relatoriobrundtland-onu-crescimento-economico-pobreza-consumo-energia-recursos-ambientaispoluicao.aspx > Acesso 2 jun. 2018.

${ }^{13}$ MILARÉ, Édis. Direito do Ambiente. p. 69.
} 
instrumento para garantir um Meio Ambiente sadio. A partir da década de 1970 há um processo de ecologização ${ }^{14}$ das constituições, norteadas principalmente pelas diretrizes e princípios da Conferencia de Estocolmo e o conceito de desenvolvimento sustentável do Relatório Brundtland. O meio ambiente, desse modo, ingressa nas Constituições em pleno período de formação do Direito Ambiental. ${ }^{15}$

\subsection{Direito fundamental ao meio ambiente ecologicamente equilibrado}

Em 1945, com o término da II Guerra Mundial, os horrores do maior conflito bélico que o mundo já viu são amplamente divulgados. A Liga das Nações, criada após a I Guerra Mundial, havia fracassado. Desse modo, as nações se unem para criar uma organização de cooperação internacional mais forte, originando a Organização das Nações Unidas (ONU). Nesse período, diante das atrocidades cometidas, debates acerca da dignidade da pessoa humana ocorrem incessantemente, originando o princípio de mesmo nome. Em 1948, é proclamada pela Assembleia Geral das Nações Unidas a Declaração Universal dos Direitos Humanos. Para ter a dignidade plenamente assegurada, uma pessoa precisa ter seus direitos humanos e direitos fundamentais garantidos. José Afonso da Silva entende por "direitos fundamentais do homem"16:

Direitos fundamentais do homem constitui a expressão mais adequada a este estudo, porque, além de referir-se a princípios que resumem a concepção do mundo e informam a ideologia política de cada ordenamento jurídico, é reservada para designar, no nível do direito positivo, aquelas prerrogativas e instituições que que ele concretiza em garantias de uma convivência digna, livre e igual de todas as pessoas. No qualitativo fundamentais acha-se a indicação de que se trata de situações jurídicas sem as quais a pessoa humana não se realiza, não convive e, às vezes, nem mesmo sobrevive; fundamentais do homem no sentido de que a todos,

14 BENJAMIN, Antonio Herman. Constitucionalização do Ambiente e Ecologização da Constituição Brasileira. In: CANOTILHO, José Joaquim Gomes; LEITE, José Rubens Morato (Org.). Direito Constitucional Ambiental Brasileiro. São Paulo: Saraiva, 2007. p. 57 - 66.

15 BENJAMIN, Antonio Herman. Constitucionalização do Ambiente e Ecologização da Constituição Brasileira. In: CANOTILHO, José Joaquim Gomes; LEITE, José Rubens Morato (Org.). Direito Constitucional Ambiental Brasileiro. São Paulo: Saraiva, 2007. p. 66.

16 "Homem" no sentido de pessoa humana.. 
por igual, devem ser, não apenas formalmente reconhecidos, mas concreta e materialmente efetivados. ${ }^{17}$

$\mathrm{Na}$ segunda metade do século XX, os direitos humanos e direitos fundamentais vão ganhando cada vez mais força e importância. Nesse mesmo momento, os impactos ambientais causados pela atividade humana tornamse ainda mais perceptíveis e alarmantes. A poluição dos centros urbanos, degradação de cursos hídricos, chuva ácida e outros fenômenos já não podiam mais ser ignorados. Nesse momento, ganha força a visão de que o Homem não mais seria o dominador da natureza, e sim parte dela, havendo uma relação de dependência entre os seres humanos e o meio ambiente.

Para uma vida sadia, do ponto de vista físico e psicológico, é fundamental que haja um meio ambiente ecologicamente equilibrado, com suas funções ambientais garantidas. O Direito ao Meio Ambiente passa a integrar, desse modo, o rol dos direitos fundamentais, apresentando as características de historicidade, inalienabilidade, imprescritibilidade e irrenunciabilidade ${ }^{18}$. Conforme Édis Milaré, o meio ambiente finalmente deixa de ser considerado um bem jurídico per accidens (casual) para se tornar um bem jurídico per se., ou seja, possuidor de valor intrínseco, conferindolhe autonomia em relação a outros bens protegidos pela ordem jurídica ${ }^{19}$.

O direito ao meio ambiente, conforme definição dada no Supremo Tribunal Federal em julgamento de 1995, através do voto do Min. Relator. Celso de Mello, muito citado na jurisprudência e doutrina, é:

Um típico direito de terceira geração que assiste, de modo subjetivamente indeterminado, a todo gênero humano, circunstância essa que justifica a especial obrigação - que incumbe ao Estado e à própria coletividade - de defendê-lo e de preservá-lo em benefício das presentes e futuras gerações. ${ }^{20}$

Os direitos de terceira geração (ou dimensão) são também conhecidos como direitos de solidariedade, pertencentes à toda a coletividade social. Conforme prossegue Celso de Mello na mencionada decisão:

\footnotetext{
${ }^{17}$ SILVA, José Afonso da. Curso de Direito Constitucional Positivo. $37^{\mathrm{a}}$ ed.. São Paulo: Malheiros, 2014. p. 180

${ }^{18}$ SILVA, José Afonso da. Curso de Direito Constitucional Positivo. p. 183

${ }^{19}$ MILARÉ, Édis. Direito do Ambiente. p 160

${ }^{20}$ STF, MS n. 22164-0-SP, Rel. Ministro Celso de Mello, Brasília, 30 out. 1995.
} 
Enquanto os direitos de primeira geração (direitos civis e políticos) - que compreendem as liberdades clássicas, negativas ou formais - realçam o princípio da liberdade e os direitos de segunda geração (direitos econômicos, sociais e culturais) - que se identificam com as liberdades positivas, reais ou concretas - acentuam o princípio da igualdade, os direitos de terceira geração, que materializam poderes de titularidade coletiva atribuídos genericamente a todas as formações sociais, consagram o princípio da solidariedade e constituem um momento importante no processo de desenvolvimento, expansão e reconhecimento dos direitos humanos, caracterizados, enquanto valores fundamentais indisponíveis, pela nota de uma essencial inexauribilidade. Considerações doutrinárias. ${ }^{21}$

O direito ao meio ambiente ecologicamente equilibrado é abordado de forma completa e expressa na Constituição Federal de 1988. Tal direito possui inclusive um capítulo próprio (Capítulo VI), e conta com um avançado dispositivo:

Art. 225. Todos têm direito ao meio ambiente ecologicamente equilibrado, bem de uso comum do povo e essencial à sadia qualidade de vida, impondo-se ao Poder Público e à coletividade o dever de defendê-lo e preservá- lo para as presentes e futuras gerações.

É importante observar que a proteção ao meio ambiente ecologicamente equilibrado, conforme prevê expressamente o caput do Art. 225 , é essencial para a própria saúde humana e qualidade de vida. Pela leitura do dispositivo percebe-se que há um dever jurídico para toda a sociedade e o Poder Público de defender e preservar o meio ambiente, de modo a mantê-lo ecologicamente equilibrado. Tal obrigação visa garantir esse direito para presentes e futuras gerações, estabelecendo o princípio da solidariedade intergeracional.

Como pontua Paulo Affonso Leme Machado, o Poder Público, gestor de um bem de uso comum do povo, inclui os três poderes da União ${ }^{22}$ : Executivo, Legislativo e Judiciário ${ }^{23}$. Os incisos do parágrafo $1^{\circ}$ do Art. 225 estabelecem deveres específicos do Poder Público para que seja cumprida a obrigação prevista no caput, dentre eles:

$\S 1^{\circ}$ Para assegurar a efetividade desse direito, incumbe ao Poder Público:

\footnotetext{
21 STF, MS n. 22164-0-SP, Rel. Ministro Celso de Mello, Brasília, 30 out. 1995.

22 "São Poderes da União, independentes e harmônicos entre si, o Legislativo, o Executivo e o Judiciário". Art 2, Constituição Federal de 1988.

23 MACHADO, Paulo Affonso Leme. Direito Ambiental Brasileiro. p. 152-154.
} 
I - preservar e restaurar os processos ecológicos essenciais e prover o manejo ecológico das espécies e ecossistemas;

III - definir, em todas as unidades da Federação, espaços territoriais e seus componentes a serem especialmente protegidos, sendo a alteração e a supressão permitidas somente através de lei, vedada qualquer utilização que comprometa a integridade dos atributos que justifiquem sua proteção;

VII - proteger a fauna e a flora, vedadas, na forma da lei, as práticas que coloquem em risco sua função ecológica, provoquem a extinção de espécies ou submetam os animais a crueldade.

Para que se tenha um meio ambiente de fato ecologicamente equilibrado o Poder Público tem o poder-dever de proteger a fauna e flora e garantir os processos ecológicos essenciais. Édis Milaré considera tais processos, em uma lista exemplificativa, como sendo:

Fixação, transformação, transporte e utilização de energia; produção, transporte, transformação e utilização de matérias várias; biodegradação de rejeitos; restituição aos corpos receptores (ar, água e solo) de suas condições e qualidades naturais; propagação e aperfeiçoamento das formas de vida num sentido evolutivo e de seleção natural; e, num sentido mais amplo, o estabelecimento de condições adequadas à perpetuação e ao aperfeiçoamento da espécie humana, sobretudo no que ela tem de específico - a racionalidade e seus valores espirituais -, uma vez que o ser humano, tanto individual como socialmente, é parte integrante do mundo natural e do meio ambiente e, no ecossistema planetário, produz cultura, conjunto de valores e práticas que determinam as inter-relações Homem-Natureza. ${ }^{24}$

Além disso, para a efetiva garantia de um meio ambiente ecologicamente equilibrado, em um país tão rico em biodiversidade e ecossistemas, são criados "espaços territoriais especialmente protegidos". Conforme o Art. 225, III, CF/88, é vedada qualquer utilização de tais áreas "que comprometa a integridade dos atributos que justifiquem sua proteção". Como exemplo desses espaços temos as Unidades de Conservação ${ }^{25}$, as Áreas de Preservação Permanente (APP) e áreas de Reserva Legal (RL). As duas últimas, previstas na Lei 12.651/12, serão abordadas detalhadamente neste trabalho.

O novo paradigma ambiental positivado no ordenamento jurídico brasileiro permeia toda a Constituição Federal, a exemplo das previsões

\footnotetext{
${ }^{24}$ MILARÉ, Édis. Direito do Ambiente. p. 175.

${ }^{25}$ A Lei 9.985, de 18 de julho de 2000, institui o Sistema Nacional de Unidades de Conservação da Natureza. Lista exemplificativa, não exaustiva.
} 
relativas à ordem econômica ${ }^{26}$ e função sociambiental da propriedade ${ }^{27}$, inaugurando um "Estado Democrático e Ecológico de Direito"28. A legislação ambiental anterior à Constituição Cidadã precisa respeitar o Art. 225 para ser recepcionada, e as normas posteriores também devem refletir a mesma disciplina constitucional relativa ao meio ambiente inaugurada em 1988. O Código Florestal de 1965 era um exemplo de norma recepcionada.

\subsection{Princípios norteadores}

Para a análise do vigente Código Florestal e a recente decisão do STF que declarou a constitucionalidade quase integral da lei, convém apresentar brevemente alguns importantes princípios que entraram em discussão na análise da Lei 12.651/2012. Optou-se por utilizar o termo "norteadores" para enfatizar a direção, caminho, norte que eles conferem à legislação ambiental de modo a concretizar cada vez mais o direito fundamental ao meio ambiente ecologicamente equilibrado.

Alguns importantes princípios foram mencionados no capítulo anterior, e estão previstos diretamente na Constituição, como por exemplo: o próprio princípio do meio ambiente ecologicamente equilibrado (Art. 225, caput); a solidariedade intergeracional (Art. 225, caput); a obrigação de intervenção do Poder Púbico na defesa do meio ambiente (Art. 225, § $1^{\circ}$ ); e a função socioambiental do direito de propriedade (Art. 186), que deve ser exercido de modo a preservar "a flora, a fauna, as belezas naturais, o

\footnotetext{
${ }^{26}$ Art. 170. A ordem econômica, fundada na valorização do trabalho humano e na livre iniciativa, tem por fim assegurar a todos existência digna, conforme os ditames da justiça social, observados os seguintes princípios:

III - função social da propriedade;

VI - defesa do meio ambiente, inclusive mediante tratamento diferenciado conforme o impacto ambiental dos produtos e serviços e de seus processos de elaboração e prestação; (Redação dada pela Emenda Constitucional no 42, de 19.12.2003)

${ }^{27}$ Art. 186. A função social é cumprida quando a propriedade rural atende, simultaneamente, segundo critérios e graus de exigência estabelecidos em lei, aos seguintes requisitos: I aproveitamento racional e adequado; II - utilização adequada dos recursos naturais disponíveis e preservação do meio ambiente; III - observância das disposições que regulam as relações de trabalho; IV - exploração que favoreça o bem-estar dos proprietários e dos trabalhadores.

${ }^{28}$ MACHADO, Paulo Affonso Leme. Direito Ambiental Brasileiro. p.152.
} 
equilíbrio ecológico e o patrimônio histórico e artístico, bem como evitada a poluição do ar e das águas"29.

Contudo, três princípios em particular serão mais abordados neste trabalho, por apresentarem evidente e direta relação com a apontada inconstitucionalidade da Lei 12.651/2012. O vigente Código Florestal traz previsões que, contrariando recomendações cientificas, potencializam danos ambientais conhecidos e outros possivelmente desconhecidos. Além disso, estabelece padrões de proteção notoriamente inferiores aos do Código Florestal de 1965. Desse modo, optou-se por dar maior ênfase aos princípios da prevenção, precaução e principalmente vedação ao retrocesso socioambiental. Entretanto, outros princípios importantes também serão mencionados ao longo deste trabalho.

Os princípios apresentados não norteiam apenas o Direito Ambiental, mas sim todo o ordenamento jurídico brasileiro, que deve respeitar a supremacia da Constituição, pautada no respeito aos direitos fundamentais. O Código florestal de 2012, porém, contém várias disposições que seguem o caminho oposto, em um período marcado por retrocessos e desmantelamentos de direitos. O Supremo Tribunal Federal, com a decisão sobre a constitucionalidade do vigente Código Florestal, contribui para essa tendência.

\subsubsection{Princípio da precaução}

A origem do princípio da precaução encontra-se no Direito alemão, em que originalmente consistia no desenvolvimento de processos que reduzissem significativamente as emissões de poluentes, em todos os setores da economia. ${ }^{30}$ Tal princípio foi aos poucos sendo reformulado e incorporado no Direito Internacional e direitos internos, mas foi a Conferência das

\footnotetext{
${ }^{29}$ Art. 1228, § $1^{\text {o }}$, Código Civil de 2002 (Lei 10.406 de 10 de janeiro de 2012).

${ }^{30}$ ANTUNES, Paulo de Bessa. Direito Ambiental. 16a ed.. São Paulo: Atlas, 2014. p. 31.
} 
Nações Unidas sobre Meio Ambiente e Desenvolvimento (Rio 92) que o lançou internacionalmente ${ }^{31}$ como é atualmente no Direito Ambiental. Conforme o Princípio 15 da "Declaração do Rio sobre Meio Ambiente e Desenvolvimento":

Com o fim de proteger o meio ambiente, o princípio da precaução deverá ser amplamente observado pelos Estados, de acordo com suas capacidades. Quando houver ameaça de danos graves ou irreversíveis, a ausência de certeza científica absoluta não será utilizada como razão para o adiamento de medidas economicamente viáveis para prevenir a degradação ambiental. ${ }^{32}$

Conforme ensina Édis Milaré, tal princípio é invocado "quando a informação cientifica é insuficiente, inconclusiva ou incerta" e seus possíveis efeitos sobre o meio ambiente, saúde das pessoas, fauna ou flora "possam ser potencialmente perigosos e incompatíveis com o nível de proteção escolhido"33. O autor utiliza como exemplo questões que envolvam o aquecimento global, engenharia genética, organismos geneticamente modificados, clonagem e exposição a campos eletromagnéticos gerados por estações de radiobase.

O Brasil implicitamente adotou os princípios da prevenção e precaução no Art. 225, IV e V, da Constituição Federal de 1988. Isso fica evidente na preocupação do legislador, respectivamente, com o controle da produção, comercialização e emprego "de técnicas, métodos e substâncias que comportem risco para a vida, a qualidade de vida e o meio ambiente" (Art. 225, IV) e a exigência de estudo prévio de impacto ambiental para a "instalação de obra ou atividade potencialmente causadora de significativa degradação do meio ambiente" (Art. 225, V).

O princípio da precaução é expressamente incorporado no ordenamento jurídico brasileiro quando o país assina, ratifica e promulga a Convenção da Diversidade Biológica e a Convenção-Quadro das Nações Unidas sobre a Mudança do Clima. As duas convenções que entraram em

\footnotetext{
${ }^{31}$ ANTUNES, Paulo de Bessa. Direito Ambiental. p. 35

32 A Declaração do Rio sobre Meio Ambiente e Desenvolvimento está disponível em <http://www.onu.org.br/rio20/img/2012/01/rio92.pdf > Acesso em 2 jun. 2018.

${ }^{33}$ MILARÉ, Édis. Direito do Ambiente. p. 264
} 
vigor em 1994 apontam como finalidade do princípio da precaução evitar ou minimizar os danos ao meio ambiente. ${ }^{34}$

O princípio da precaução aparece constantemente em jurisprudência pacífica do STF e STJ. Conforme o entendimento pacificado dos tribunais:

O princípio da precaução é um critério de gestão de risco a ser aplicado sempre que existirem incertezas científicas sobre a possibilidade de um produto, evento ou serviço desequilibrar o meio ambiente ou atingir a saúde dos cidadãos, o que exige que o estado analise os riscos, avalie os custos das medidas de prevenção e, ao final, execute as ações necessárias, as quais serão decorrentes de decisões universais, não discriminatórias, motivadas, coerentes e proporcionais. ${ }^{35}$

A decisão acima ainda faz menção à ideia de proporcionalidade, que apareceu também no julgamento das ações do Código Florestal de 2012. O princípio da proporcionalidade será abordado junto com o princípio da vedação ao retrocesso socioambiental.

\subsubsection{Princípio da prevenção}

Ainda há certa confusão e divergência na doutrina acerca da diferença entre os princípios da prevenção e precaução, o que também ocorre na jurisprudência. Assim, é comum encontrar a utilização de apenas um dos termos para englobar os dois princípios.

Porém, fica evidente ao se analisar a etimologia das duas palavras que a prevenção trata de ou impactos já conhecidos, certos, concretos; enquanto a precaução trata de riscos ou impactos desconhecidos, incertos, abstratos. ${ }^{36} \mathrm{~A}$ ideia de prevenir está presente no ordenamento jurídico principalmente na forma dos estudos de impacto ambiental e licenciamento ambiental, de modo a minimizar os danos que podem ser causados ao meio ambiente por determinada atividade ${ }^{37}$. Em relação ao postulado da prevenção, o Ministro

\footnotetext{
${ }^{34}$ MACHADO, Paulo Affonso Leme. Direito Ambiental Brasileiro. p. 98, 99.

${ }^{35}$ STF, RE n. 627189, Rel. Ministro Dias Toffoli, Brasília, 06 jun. 2016.

${ }^{36}$ MILARÉ, Édis. Direito do Ambiente. p. 262, 263.

${ }^{37}$ ANTUNES, Paulo de Bessa. Direito Ambiental. p. 48.
} 
Celso de Mello, no julgamento conjunto das ADIs 4901, 4902, 4903, 4937 e

ADC 42 no Plenário do STF, enfatizou que:

É de destacar-se, bem por isso, que a União Federal, ao editar a legislação em matéria ambiental, deve adequar-se, para fins de observância e respeito ao princípio que veda a proteção insuficiente, ao postulado da prevenção, que se mostra aplicável a situações apoiadas na existência de certeza científica quanto à nocividade de medidas cuja execução culmine por afetar, mesmo potencialmente, a incolumidade do meio ambiente, como sucederia, p. ex., nos casos de devastação florestal ou de degradação ambiental provocadas pela ação predatória do homem. ${ }^{38}$

Os princípios da prevenção, precaução e da responsabilização das condutas lesivas ao meio ambiente estão interligados por outro princípio norteador do Direito Ambiental: o princípio do poluidor-pagador ${ }^{39}$.Tal princípio, assim como a precaução e prevenção, também tem suas origens diretamente ligadas à Economia, mas foi sendo desenvolvido até assumir papel de destaque no Direito Ambiental. Pelo princípio do poluidor-pagador, as atividades potencialmente causadoras de degradação do meio ambiente devem internalizar os custos ambientais decorrentes de seu funcionamento:

Procura-se imputar ao poluidor o custo social da poluição por ele gerada ou que ele é capaz de gerar. É importante deixar claro que o princípio do poluidor-pagador não pode ser distorcido com o propósito de justificar a tolerância da poluição mediante o pagamento de um "preço". Da mesma forma, esse comando não se limita a ordenar a reparação dos danos ambientais, mas também a responsabilização pela prevenção. Logo, em seu conteúdo estão embutidos todos os custos da proteção do meio ambiente, entre os quais os ligados ao uso dos recursos ambientais. ${ }^{40}$ (grifos meus)

Os postulados da prevenção e precaução, como pode-se perceber, influenciam diretamente outros princípios do Direito Ambiental. Tais princípios funcionam, inclusive, como suportes do princípio da vedação ao retrocesso.

\subsubsection{Princípio da vedação ao retrocesso socioambiental}

\footnotetext{
${ }^{38}$ STF, ADIs n. 4901, 4902, 4903, 4937 e ADC n. 42, Rel. Ministro Luiz Fux, Brasília. Julgamento conjunto no Plenário concluído em 28 fev. 2018.

39 MOREIRA, Danielle de Andrade. Responsabilidade ambiental pós-consumo: prevenção e reparação de danos à luz do princípio do poluidor-pagador. São Paulo: Letras Jurídicas; Rio de Janeiro: Ed. PUC-Rio, 2015. p. 85.

${ }^{40}$ MOREIRA, Danielle de Andrade. Responsabilidade ambiental pós-consumo. p. 85
} 
Os direitos fundamentais são uma importantíssima conquista da sociedade. Muitas vezes, para sua preservação, concretização ou ampliação, são redigidas novas leis. Porém, legislação posterior à consolidação de determinado direito pode afetar ou até desconstruir a sua manutenção, de modo a ameaçá-lo. Alterações que visem a diminuir a proteção dada ao direito ao meio ambiente ecologicamente equilibrado, construída e consolidada na legislação ao longo de muitos anos, devem ser coibidas.

O princípio da vedação ao retrocesso (ou não regressão) é um princípio chave para a percepção de que o Código Florestal de 2012 é um ataque direto à proteção ambiental que a Constituição Federal de 1988 almejava. Michel Prieur verifica inclusive como alguns princípios clássicos (como prevenção e precaução) do direito ambiental podem ser interpretados como suporte da não regressão:

A prevenção impede o recuo das proteções; a sustentabilidade e as gerações futuras enviam à perenidade e à intangibilidade para preservar os direitos de nossos descendentes de poderem gozar de um ambiente não degradado; a precaução permite que a irreversibilidade seja evitada, esta um exemplo claro de regressão definitiva; a participação e a informação do público permitem a garantia de um nível de proteção suficiente, graças a um controle cidadão permanente. ${ }^{41}$

Para Édis Milaré, a retroatividade proibida, nesses casos, é aquela que ameaça a proteção de um direito fundamental ${ }^{42}$. De acordo com o autor:

a proibição do retrocesso em matéria ambiental vem exatamente no sentido de garantir que no avançar do tempo, e da edição de novas normas e sua aplicação, se mantenha ou avance também a proteção do meio ambiente, não se admitindo sua flexibilização e, jamais, sua redução. ${ }^{43}$

Herman Benjamin defende que as mudanças legislativas e mecanismos de salvaguarda dos direitos humanos e do patrimônio natural das gerações futuras devem "caminhar somente para frente" 44 . O princípio

\footnotetext{
${ }^{41}$ PIEUR, Michel. O princípio da proibição de retrocesso ambiental. In: Senado Federal. Princípio da Proibição de Retrocesso Ambiental. Brasília: Senado Federal, 2012. Disponível em <http://www2.senado.gov.br/bdsf/handle/id/242559> p. 17.

${ }^{42}$ MILARÉ, Édis. Direito do Ambiente. p. 276.

${ }^{43}$ MILARÉ, Édis. Direito do Ambiente. p. 277.

${ }^{44}$ BENJAMIN, Herman. O princípio da proibição de retrocesso ambiental. In: Senado Federal. Princípio da Proibição de Retrocesso Ambiental. Brasília: Senado Federal, 2012. Disponível em <http://www2.senado.gov.br/bdsf/handle/id/242559> p. 57.
} 
da não regressão é importante a ponto de Herman Benjamin, Ministro do STJ, conferir-lhe o patamar de princípio geral do Direito Ambiental:

É seguro afirmar que a proibição de retrocesso, apesar de não se encontrar, com nome e sobrenome, consagrada na nossa Constituição, nem em normas infraconstitucionais, e não obstante sua relativa imprecisão - compreensível em institutos de formulação recente e ainda em pleno processo de consolidação -, transformou-se em princípio geral do Direito Ambiental, a ser invocado na avaliação da legitimidade de iniciativas legislativas destinadas a reduzir o patamar de tutela legal do meio ambiente, mormente naquilo que afete em particular a) processos ecológicos essenciais, b) ecossistemas frágeis ou à beira de colapso, e c) espécies ameaçadas de extinção. ${ }^{45}$

Obviamente, o princípio da vedação ao retrocesso não é absoluto. Outros princípios devem ser considerados na análise de norma que verse sobre o direito ao meio ambiente ecologicamente equilibrado, como a dignidade da pessoa humana ${ }^{46}$, devendo haver a observação dos princípios da proporcionalidade e razoabilidade. Incumbe ao Estado, conforme Ingo Wolfgang Sarlet e Tiago Fensterseifer, a ação estatal que se situa no âmbito de uma "dupla face" do princípio da proporcionalidade, "entre a proibição de excesso de intervenção, por um lado, e a proibição da insuficiência de proteção, por outro" 47 .

Porém, como esclarecem Ingo Wolfgang Sarlet e Tiago Fensterseifer, havendo violação ao núcleo essencial do direito fundamental ao ambiente e também do próprio mínimo existencial socioambiental, “impõe-se a decretação da inconstitucionalidade da lei em questão"48. Para os autores, "isso ocorre de forma cristalina nas alterações pretendidas para o Código Florestal Brasileiro"49.

\footnotetext{
${ }^{45}$ BENJAMIN, Herman. O princípio da proibição de retrocesso ambiental. In: Senado Federal. Princípio da Proibição de Retrocesso Ambiental. Brasília: Senado Federal, 2012. Disponível em <http://www2.senado.gov.br/bdsf/handle/id/242559> p. 62

${ }^{46}$ MOLINARO, Carlos Alberto. O princípio da proibição de retrocesso ambiental. In: Senado Federal. Princípio da Proibição de Retrocesso Ambiental. Brasília: Senado Federal, 2012. Disponível em http://www2.senado.gov.br/bdsf/handle/id/242559 p. 98

${ }^{47}$ SARLET, Ingo Wolfgang; FENSTERSEIFER, Tiago. Código Florestal: 45 anos: estudos e reflexoes / Guilherme José Purvin de Figueiredo, Lindamar Monteiro da Silva, Marcelo abelha Rodrigues e Márcia Dieguez Leuzinger (organizadores). Curitiba: Letra da Lei , 2010. p. 36

${ }^{48}$ SARLET, Ingo Wolfgang; FENSTERSEIFER, Tiago. O princípio da proibição de retrocesso ambiental. In: Senado Federal. Princípio da Proibição de Retrocesso Ambiental. Brasília: Senado Federal, 2012. Disponível em http://www2.senado.gov.br/bdsf/handle/id/242559 p. 192.

${ }^{49}$ SARLET, Ingo Wolfgang; FENSTERSEIFER, Tiago. O princípio da proibição de retrocesso ambiental. In: Senado Federal. Princípio da Proibição de Retrocesso Ambiental. Brasília: Senado Federal, 2012. Disponível em http://www2.senado.gov.br/bdsf/handle/id/242559 p. 192.
} 
Conforme Letícia Lima, não é simples delimitar precisamente o que seria tal núcleo essencial e mínimo existencial socioambiental ${ }^{50}$, que gera amplos debates na doutrina, os quais não convém abordar. Entretanto, com base nos pontos em comum entre a visão de diversos autores nessa discussão, Letícia Lima revela que o necessário é perceber como tal mínimo ecológico é dinâmico, sendo ampliado conforme o surgimento de novas tecnologias, consolidando "padrões de proteção ambiental mais altos" $"$. Isso possibilita que haja mais eficiência na "diminuição da poluição e dos processos produtivos danosos ao meio ambiente, uma melhor fiscalização dos mesmos, além de mecanismos de reparação mais eficazes" $" 52$.

Michel Prieur, por exemplo, entende que o limite do conceito de mínimo essencial varia de acordo com o território e recursos econômicos de um Estado, e depende de indicadores ambientais científicos e jurídico ${ }^{53}$. Contudo, conforme observa o autor, as exigências internacionais sempre impõem "um nível elevado de proteção", incompatíveis com "qualquer tolerância que signifique regressão, reduzindo a proteção a níveis mínimos, com o risco de serem muito baixos" 54 . Desse modo, o autor conclui que o conteúdo mínimo em matéria ambiental deveria ser "a proteção máxima, consideradas as circunstancias locais". 55

\footnotetext{
50 LIMA, Letícia Maria Rêgo Teixeira. O novo Código Florestal (LEI 12.651/2012) à luz do princípio da vedação ao retrocesso socioambiental. Trabalho de Conclusão de Curso - Faculdade de Direito, Pontifícia Universidade Católica do Rio de Janeiro, Rio de Janeiro. 2015. Disponível em https://www.maxwell.vrac.puc-rio.br/26087/26087.PDF p. 26.

51 LIMA, Letícia Maria Rêgo Teixeira. O novo Código Florestal (LEI 12.651/2012) à luz do princípio da vedação ao retrocesso socioambiental. Trabalho de Conclusão de Curso - Faculdade de Direito, Pontifícia Universidade Católica do Rio de Janeiro, Rio de Janeiro. 2015. Disponível em https://www.maxwell.vrac.puc-rio.br/26087/26087.PDF p. 26.

52 LIMA, Letícia Maria Rêgo Teixeira. O novo Código Florestal (LEI 12.651/2012) à luz do princípio da vedação ao retrocesso socioambiental. Trabalho de Conclusão de Curso - Faculdade de Direito, Pontifícia Universidade Católica do Rio de Janeiro, Rio de Janeiro. 2015. Disponível em https://www.maxwell.vrac.puc-rio.br/26087/26087.PDF p. 26.

${ }^{53}$ PRIEUR, Michel. O princípio da proibição de retrocesso ambiental. p. 46.

${ }^{54}$ PRIEUR, Michel. O princípio da proibição de retrocesso ambiental. p. 47.

${ }^{55}$ PRIEUR, Michel. O princípio da proibição de retrocesso ambiental. p. 47.
} 
Letícia Lima, assim, conclui que existe no Direito brasileiro, "três núcleos duros que representam o mínimo existencial ecológico" "56, listados no Art $225, \S 1^{\circ}$, I, II e VII da Constituição Federal:

Art. 225. Todos têm direito ao meio ambiente ecologicamente equilibrado, bem de uso comum do povo e essencial à sadia qualidade de vida, impondo-se ao poder público e à coletividade o dever de defendê-lo e preservá-lo para as presentes e futuras gerações.

$\S \mathbf{1}^{\mathbf{0}}$ Para assegurar a efetividade desse direito, incumbe ao poder público:

I - preservar e restaurar os processos ecológicos essenciais e prover o manejo ecológico das espécies e ecossistemas;

II - preservar a diversidade e a integridade do patrimônio genético do País e fiscalizar as entidades dedicadas à pesquisa e manipulação de material genético;

VII - proteger a fauna e a flora, vedadas, na forma da lei, as práticas que coloquem em risco sua função ecológica, provoquem a extinção de espécies ou submetam os animais a crueldade. (Grifos meus)

Conforme consta na petição inicial da ADI 4901, o Código Florestal de 2012 é uma afronta aos três núcleos levantados por Letícia Lima e à "vedação de que espaços territoriais especialmente protegidos sejam utilizados de forma que comprometa os atributos que justificam sua proteção" 57 . Concluiu-se, no citado documento, que "ao fragilizar o regime de proteção das APPs e RLs", “o legislador infraconstitucional atingiu o núcleo fundamental do direito ao meio ambiente ecologicamente equilibrado":

$\mathrm{E}$, ao fragilizar o regime de proteção das áreas de preservação permanente e das reservas legais, e em alguns casos, extingui-las, o legislador infraconstitucional violou integralmente os mandamentos constitucionais acima mencionados. Se, na lição de Konrad Hesse, "direitos fundamentais não podem existir sem deveres", é forçoso reconhecer que o legislador infraconstitucional atingiu o núcleo fundamental do direito ao meio ambiente ecologicamente equilibrado, negando-lhe vigência e retirando sua força normativa. ${ }^{58}$

A petição inicial da ADI 4901 ainda vai além, e reconhece que "as normas impugnadas violam o princípio da vedação de retrocesso social”,

\footnotetext{
${ }^{56}$ LIMA, Letícia Maria Rêgo Teixeira. O novo Código Florestal (LEI 12.651/2012) à luz do princípio da vedação ao retrocesso socioambiental. Trabalho de Conclusão de Curso - Faculdade de Direito, Pontifícia Universidade Católica do Rio de Janeiro, Rio de Janeiro. 2015. Disponível em https://www.maxwell.vrac.puc-rio.br/26087/26087.PDF p. 27

${ }^{57}$ STF, ADI n. 4901, Rel. Ministro Luiz Fux, Brasília. Julgamento conjunto no Plenário do STF, concluído em 28 fev. 2018. Petição Inicial ajuizada pelo Ministério Público Federal, em 18 jan. 2013. p. 12.

${ }^{58}$ STF, ADI n. 4901, Rel. Ministro Luiz Fux, Brasília. Julgamento conjunto no Plenário do STf, concluído em 28 fev. 2018. Petição Inicial ajuizada pelo Ministério Público Federal, em 18 jan. 2013. p. 13.
} 
nesse caso, retrocesso ambiental, devido ao estabelecimento de padrões de proteção claramente inferiores aos do Código de $1965 .{ }^{59}$

O princípio da vedação ao retrocesso teve seu alcance discutido no Supremo Tribunal Federal no julgamento das quatro ADIs e da ADC relativas ao Código Florestal, como será visto adiante neste trabalho. Tal princípio, apesar de aparecer pouco em matéria ambiental, foi consolidado na jurisprudência em 2010 no Superior Tribunal de Justiça com o EREsp 418.526/SP, Rel. Min. Teori Albino Zavascki; e REsp 302.906/SP, Rel. Min. Herman Benjamin ${ }^{60}$. Em seu voto relativo a um caso de Direito Ambiental e Urbanístico, Herman Benjamin entende que:

Submete-se ao princípio da não-regressão (ou, por outra terminologia, princípio da proibição de retrocesso), garantia de que os avanços urbanístico-ambientais conquistados no passado não serão diluídos, destruídos ou negados pela geração atual ou pelas seguintes [...] palavras ditas por juízes podem, sim, estimular a destruição ou legitimar a conservação, referendar a especulação ou garantir a qualidade urbanístico-ambiental, consolidar erros do passado, repeti-los no presente, ou viabilizar um futuro sustentável. ${ }^{61}$

Antes de entrar propriamente na análise do Código Florestal vigente, declarado constitucional em quase sua totalidade, convém citar os questionamentos que legisladores e juízes deveriam fazer ao analisar projetos que versem sobre o meio ambiente, à luz dos princípios norteadores do Direito Ambiental e as das previsões do Art. 225, CF/88, sobre a proteção do direito ao meio ambiente ecologicamente equilibrado:

As alterações legislativas ou políticas de implementação mantêm ou ampliam as garantias do meio ambiente? Asseguram a proteção dos "processos ecológicos essenciais"? Escudam, eficaz e eficientemente, as espécies ameaçadas de extinção? Ampliam ou reduzem os riscos ambientais a habitats vulneráveis? Estabelecem, naquilo que se revisa ou modifica, alternativas técnicas capazes de alcançar os mesmos ou similares resultados da norma ou política de implementação revogada? Reduzem ou mantêm o grau de dificuldade de execução, bem como de cobrança administrativa e judicial (os chamados custos de transação da execução da lei)? ${ }^{62}$

\footnotetext{
${ }^{59}$ STF, ADI n. 4901, Rel. Ministro Luiz Fux, Brasília. Julgamento conjunto no Plenário do STF, concluído em 28 fev. 2018. Petição Inicial ajuizada pelo Ministério Público Federal, em 18 jan. 2013. p. 13.

60 BENJAMIN, Herman. O princípio da proibição de retrocesso ambiental. In: Senado Federal. Princípio da Proibição de Retrocesso Ambiental. Brasília: Senado Federal, 2012. Disponível em <http://www2.senado.gov.br/bdsf/handle/id/242559> p. 63.

${ }^{61}$ STJ, Resp n. 302.906/SP, Rel. Ministro Herman Benjamin, Brasília, 26 ago. 2010.

${ }^{62}$ BENJAMIN, Herman. O princípio da proibição de retrocesso ambiental. In: Senado Federal. Princípio da Proibição de Retrocesso Ambiental. Brasília: Senado Federal, 2012. Disponível em <http://www2.senado.gov.br/bdsf/handle/id/242559> p. 70.
} 
As respostas dessas perguntas em relação às alterações legislativas do Código Florestal de 2012 são preocupantes. A Lei 12.651/2012, como será visto no próximo capítulo, diminui as garantias do meio ambiente, não assegura a proteção dos "processos ecológicos essenciais", torna as espécies ameaçadas de extinção mais vulneráveis e amplia os riscos ambientais a habitats vulneráveis, dentre outros problemas. Além disso, confere anistia aos proprietários rurais que desmataram anteriormente à data de 22 de julho de 2008, o que cria um regime benéfico para tais sujeitos e pode incentivar novos retrocessos. 


\section{O CÓDIGO FLORESTAL DE 2012 NO SUPREMO TRIBUNAL FEDERAL}

\subsection{Breve histórico da Lei $12.651 / 2012$}

O primeiro Código Florestal brasileiro (Decreto 23.793) foi editado em 1934, mesmo ano da Constituição de 1934, que inovou ao considerar a proteção da natureza um princípio fundamental. Apesar do objetivo principal ser a exploração madeireira no país, a classificação das florestas em 4 categorias (florestas protetoras, florestas remanescentes, florestas de rendimento e florestas modelo) foi um mérito importante ${ }^{63}$.

Com o Código Florestal de 1965 (Lei federal 4.771), as tipologias da lei anterior foram substituídas por 4 outras: Parque Nacional, Floresta Nacional, Áreas de Preservação Permanente (APP) e Reserva Legal (RL) ${ }^{64}$. Os limites legais estabelecidos pelo Código Florestal de 1965 (Lei federal 4.771) ainda estavam distantes, visto que os grandes ecossistemas, como Cerrado, Pantanal Mato-Grossense, Floresta Amazônica e Mata Atlântica (bioma mais devastado do país) ainda apresentavam extensas áreas contínuas e intocadas ${ }^{65}$. Diante de tal panorama, a oligarquia rural não se insurgiu contra a promulgação da lei na década de $1960^{66}$. Porém, a mecanização do setor agropecuário e políticas de incentivo do Poder Público,

\footnotetext{
${ }^{63}$ STF, ADI n. 4901, Rel. Ministro Luiz Fux, Brasília. Julgamento conjunto em Plenário, concluído em 28 fev. 2018. Petição Inicial ajuizada pelo Ministério Público Federal, em 18 jan. 2013. p. 3. ${ }^{64}$ STF, ADI n. 4901, Rel. Ministro Luiz Fux, Brasília. Julgamento conjunto em Plenário, concluído em 28 fev. 2018. Petição Inicial ajuizada pelo Ministério Público Federal, em 18 jan. 2013. p. 4.

${ }^{65}$ FIGUEIREDO, Guilherme José Purvin; LEUZINGER, Márcia Dieguez. Anotações atualizadas acerca do Processo Legislativo de Reforma do Código Florestal. In: FIGUEIREDO, Guilherme José Purvin et al (Org.). Código Florestal:45 anos: estudos e reflexões. Curitiba: Letra da Lei; São Paulo: IBAP, 2010. p. 17-30.

${ }^{66}$ FIGUEIREDO, Guilherme José Purvin; LEUZINGER, Márcia Dieguez. Anotações atualizadas acerca do Processo Legislativo de Reforma do Código Florestal. In: FIGUEIREDO, Guilherme José Purvin et al (Org.). Código Florestal:45 anos: estudos e reflexões. Curitiba: Letra da Lei; São Paulo: IBAP, 2010. p. 17-30.
} 
além de outros fatores, geraram uma ampla e rápida expansão da fronteira agrícola.

A acelerada expansão da fronteira agrícola foi marcada pelo desrespeito a diversos direitos fundamentais além do direito ao meio ambiente ecologicamente equilibrado. Os conflitos pelo acesso à terra e as fraudes se intensificaram, sobretudo em locais distantes de uma área com efetiva atuação e fiscalização do Poder Público e da sociedade. Além disso, em muitas propriedades rurais foram constatados trabalhadores em condições análogas à escravidão, situação que existe até os dias atuais no Brasil, nas áreas rurais e urbanas. Diante de uma expansão que muitas vezes esteve marcada pelo desrespeito aos direitos fundamentais, o Código Florestal de 1965 não foi cumprido, mesmo com a presença de extensas áreas contínuas e intocadas dos principais biomas nacionais.

Atualmente, no século XXI, tal expansão já atinge a região Norte e a Floresta Amazônica. Esse avanço é um dos principais fatores de ameaça aos biomas brasileiros, como o Cerrado ${ }^{67}$, que vem sendo degradado num ritmo alarmante, principalmente na região do MATOPIBA (formada pelos estados do Maranhão, Tocantins, Piauí e Bahia) ${ }^{68}$. A figura que será apresentada abaixo mostra a localização dos principais biomas do Brasil. $\mathrm{O}$ arco do desmatamento (em vermelho) demonstra onde o a fronteira agrícola já chegou:

\footnotetext{
${ }^{67}$ O Cerrado, segundo maior bioma do Brasil, é um "hotspot" de biodiversidade e contribui para 2/3 das regiões hidrográficas brasileiras. Porém, não recebe a devida importância das autoridades nacionais, não contando com programas de monitoramento como possui a Floresta Amazônica. A expansão descontrolada da agropecuária nas últimas 4 décadas, incentivada pelo Poder Público, já levou à perda de 52\% do bioma. Nos moldes de: PITTA, Fábio Teixeira et al.. Impactos da expansão do agronegócio no MATOPIBA: comunidade e meio ambiente. Disponível em<http://semcerrado.org.br/wpcontent/uploads/2017/09/1505227050ACTIONAID_MATOPIBA_PORT_WEB 05SET.pdf> Acesso em 2 jun. 2018. 2 jun. 2018.

${ }^{68}$ PITTA, Fábio Teixeira et al.. Impactos da expansão do agronegócio no MATOPIBA: comunidade e meio ambiente. Disponível em <http://semcerrado.org.br/wpcontent/uploads/2017/09/1505227050ACTIONAID_MATOPIBA_PORT_WEB 05SET.pdf> Acesso em 2 jun. 2018. 2 jun. 2018 .p. 4-9.
} 


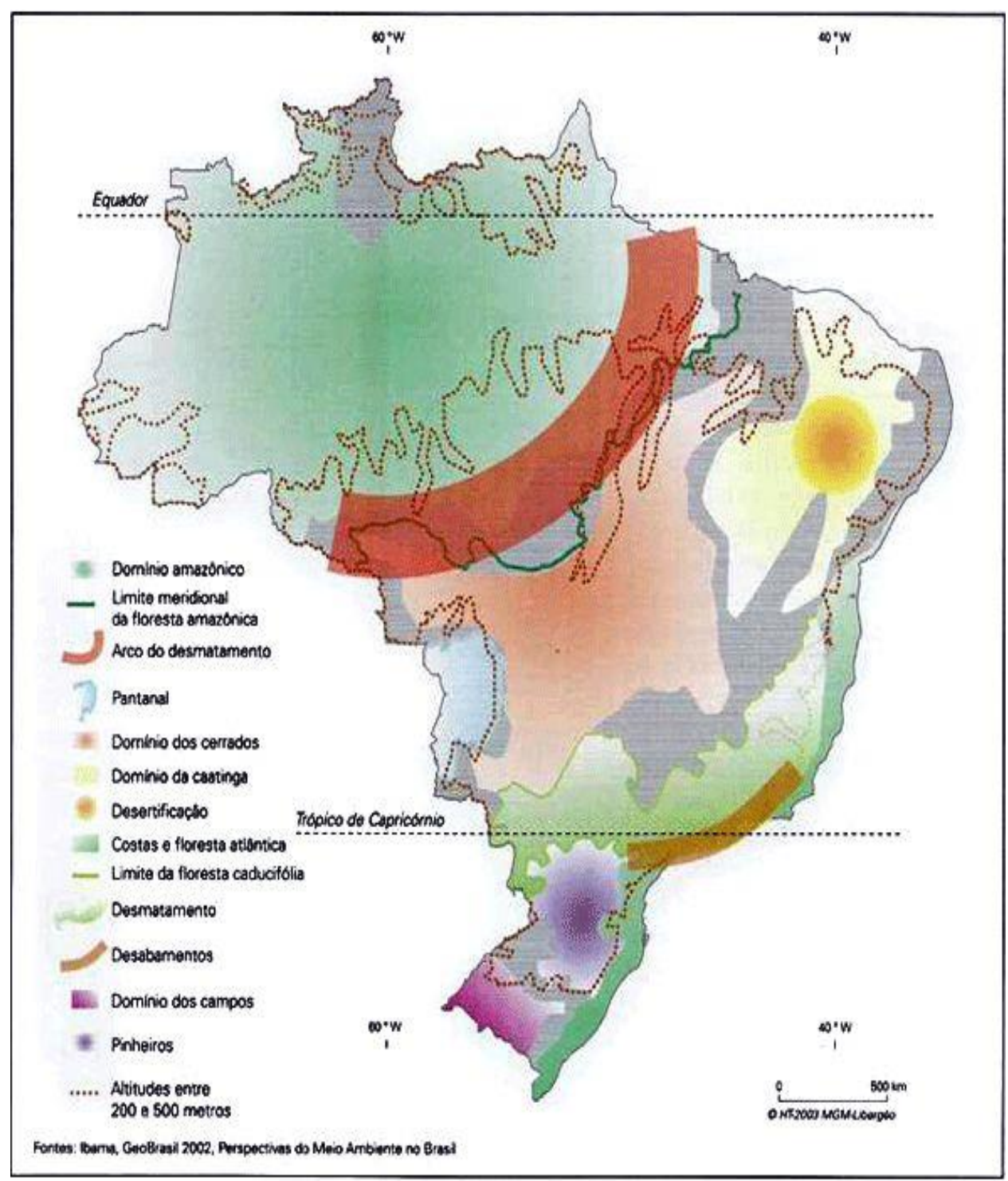

$\mathrm{O}$ incessante avanço da fronteira agrícola no final do século XX contou com amplo descumprimento do Código Florestal de 1965. Entretanto, o Direito Ambiental brasileiro continuou avançando em direção a uma maior proteção do meio ambiente, a exemplo da Política Nacional do Meio Ambiente (Lei 6.938/1981). Com a Constituição de 1988 e sua ordem pautada nos direitos humanos e dignidade da pessoa humana, o direito ao

\footnotetext{
69. Imagem disponível em: TAVARES, Vinícius. Meio Ambiente debate os impactos do avanço da fronteira agrícola no bioma Cerrado. Disponível em http://www.olhardireto.com.br/agro/noticias/exibir.asp?id=14533\&noticia=meio-ambiente-debateos-impactos-do-avanco-da-fronteira-agricola-no-bioma-cerrado ; Extraída de IBAMA; GeoBrasil 2002. Perspectivas do Meio Ambiente no Brasil. Brasília: Edições IBAMA, 2002. Disponível em http://www.ibama.gov.br/sophia/cnia/site_cnia/geo brasil_2002.pdf Acesso em 2 jun. 2018. 2 jun. 2018.
} 
meio ambiente ecologicamente equilibrado passou a ter um artigo próprio (Art. 225), que influenciaria todo o ordenamento jurídico. Diante da pressão internacional devido ao alarmante desmatamento ${ }^{70}$ na Amazônia Legal na década de 1990, o próprio Código Florestal de 1965 foi alterado, de modo a introduzir medidas ainda mais protetivas (como fez a Medida Provisória $1.511 / 1996)^{71}$. Nesse mesmo período, tornaram-se constantes as tentativas de retrocesso ambiental no Congresso Nacional ${ }^{72}$.

Ainda na década de 1990, foi promulgada a Lei de Crimes Ambientais $\left(\right.$ Lei 9.605/1998) ${ }^{73}$. A inobservância de dispositivos do Código Florestal, desse modo, levaria a sanções penais e administrativas. No ano de 2008, a Lei de Crimes Ambientais é regulamentada pelo Decreto 6.514, que "dispõe sobre as infrações e sanções administrativas ao meio ambiente" e "estabelece o processo administrativo federal para apuração destas infrações”. Esses instrumentos exemplificam a adoção de medidas que possibilitaram maior fiscalização e aplicação do Código Florestal de $1965^{74}$.

A bancada ruralista ${ }^{75}$ do Congresso Nacional, com a nova situação, vê na legislação ambiental brasileira um obstáculo para os seus interesses.

\footnotetext{
${ }^{70}$ No período de 1994-1995 foram desmatados 29.059 km², conforme observável em gráfico presente no seguinte artigo: SOUZA, Oswaldo Braga de. Desmatamento na Amazônia explode entre 2015 e 2016. Disponível em https://www.socioambiental.org/pt-br/noticias-socioambientais/desmatamento-naamazonia-explode-entre-2015-e-2016 ; elaborado a partir de dados do PRODES/INPE, disponíveis em: <http://www.inpe.br/noticias/noticia.php?Cod_Noticia=4344 $\geq$ Acesso em 2 jun. 2018.

${ }^{71}$ LIMA, Letícia Maria Rêgo Teixeira. O novo Código Florestal (LEI 12.651/2012) à luz do princípio da vedação ao retrocesso socioambiental. Trabalho de Conclusão de Curso - Faculdade de Direito, Pontifícia Universidade Católica do Rio de Janeiro, Rio de Janeiro. 2015. Disponível em https://www.maxwell.vrac.puc-rio.br/26087/26087.PDF p. 38.

${ }^{72}$ FIGUEIREDO, Guilherme José Purvin; LEUZINGER, Márcia Dieguez. Anotações atualizadas acerca do Processo Legislativo de Reforma do Código Florestal. In: FIGUEIREDO, Guilherme José Purvin et al (Org.). Código Florestal:45 anos: estudos e reflexões. Curitiba: Letra da Lei; São Paulo: IBAP, 2010. p. 17-30.

73 Apesar de mencionada na maioria das vezes pelo nome "Lei de Crimes Ambientais", ela dispõe sobre as sanções penais e administrativas derivadas de condutas e atividades lesivas ao meio ambiente.

${ }^{74}$ LIMA, Letícia Maria Rêgo Teixeira. O novo Código Florestal (LEI 12.651/2012) à luz do princípio da vedação ao retrocesso socioambiental. Trabalho de Conclusão de Curso - Faculdade de Direito, Pontifícia Universidade Católica do Rio de Janeiro, Rio de Janeiro. 2015. Disponível em https://www.maxwell.vrac.puc-rio.br/26087/26087.PDF p. 39.

${ }^{75}$ A bancada ruralista é formada principalmente pela Frente Parlamentar da Agropecuária (FPA), e tem enorme influência e articulação política no Congresso Nacional e com o Planalto. Frequentemente defende pautas conservadoras, formando alianças com membros da bancada evangélica e bancada armamentista. Recentemente, defenderam mais de uma vez projetos que enfraquecem diversos direitos conquistados, colocando em risco: a proteção ambiental, direitos indígenas e a própria vedação ao trabalho em condições análogas à escravidão. Em 2012, tal bancada
} 
Inicialmente, tentaram alterar o Código Florestal de 1965 por meio de medidas provisórias, o que falhou. Posteriormente, o Projeto de Lei 1.876/99 e seus diversos apensos, como o PL 5.367/09, acabaram originando a Lei 12.651/2012, O novo Código Florestal.

Uma década de articulações políticas entre diversos partidos, envolvendo o Planalto e o Legislativo, deu forma à nova lei. Nesse período, a comunidade científica demonstrou com estudos e dados o perigo do retrocesso proporcionado. Mesmo com mais de 70 audiências públicas, prevaleceram os interesses da bancada ruralista, que ficava cada vez mais influente no Congresso Nacional ${ }^{76}$. A sociedade brasileira, incluindo ONGs, artistas, ambientalistas, professores de Direito ambiental, constitucionalistas e cientistas, fez forte apelo para que Dilma Roussef vetasse integralmente a o Código Florestal aprovado pela Câmara dos Deputados em 2011. A Presidente, contrariando o pedido do movimento "Veta Dilma", fez 12 vetos pontuais. Grande parte da população e da mídia, desconhecedores dos detalhes legais, achou que o seu pedido fora acatado ${ }^{77}$. Movimentos de organizações da sociedade civil continuaram exigindo mudanças, mas com o tempo também foram perdendo alcance.

Desse modo, entrou em vigor um novo Código Florestal, que diminui expressivamente os padrões de proteção de APP e RL, em desconformidade com as recomendações da comunidade científica, e prevê ampla anistia a proprietários que desmataram antes de 22 de julho de 2008. Não havia crise na agricultura brasileira que justificasse tamanho retrocesso em relação ao

dizia influenciar ao menos $41 \%$ dos votos da Câmara dos Deputados, conforme matéria da BBC Brasil de tal ano: FELLET, João. Maior lobby no Congresso, ruralistas controlam 1/4 da Câmara. Disponível em <http://www.bbc.com/portuguese/noticias/2012/05/120524_ruralistas_abre_jf > Acesso em 2 jun. 2018.2 jun. 2018.

${ }^{76}$ A influência da bancada ruralista e o empenho em desconstruir a legislação ambiental cresciam cada vez mais na década de 2000, como pode-se perceber em matéria do ano de 2008: CAMARGO, Renata. Ruralistas avançam sobre o meio ambiente no Congresso. Disponível em $<$ http://congressoemfoco.uol.com.br/noticias/ruralistas-avancam-sobre-o-meio-ambiente-nocongresso/> Acesso em 2 jun. 2018. 2 jun. 2018.

77 LIMA, Letícia Maria Rêgo Teixeira. O novo Código Florestal (LEI 12.651/2012) à luz do princípio da vedação ao retrocesso socioambiental. Trabalho de Conclusão de Curso - Faculdade de Direito, Pontifícia Universidade Católica do Rio de Janeiro, Rio de Janeiro. 2015. Disponível em https://www.maxwell.vrac.puc-rio.br/26087/26087.PDF p. 38. 
Código Florestal de 1965, como apontou Guilherme José Purvin de

Figueiredo, coordenador Geral da Associação dos Professores de Direito Ambiental do Brasil (APRODAB):

De acordo com a Estatística da Produção Agrícola de Abril de 2012, do IBGE, a área de produção de soja em nosso país equivale a aproximadamente 25 milhões de hectares. A área destinada ao plantio de cana de açúcar é de quase 10 milhões de hectares. Estas duas áreas somadas perfazem quase 35 milhões de hectares, ao passo que, se se somarmos as áreas destinadas à produção de alimentos à população (feijão, arroz, laranja, cebola, aveia, trigo, cevada, amendoim, cacau, café, mandioca, batata), não chegaremos a 15 milhões de hectares. As exportações de soja em grão totalizaram 1,57 milhão de toneladas em fevereiro de 2012, segundo o Ministério do Desenvolvimento, Industria e Comercio Exterior (MDIC). O faturamento foi de US\$715,5 milhões. O crescimento anual do volume exportado foi equivalente a sete vezes mais do que o total apurado em fevereiro de 2011. Estes elementos demonstram que a agricultura brasileira não está em crise, não prioriza a produção de alimentos e tampouco é voltada para o mercado interno. O grande consumidor da soja brasileira é a China. ${ }^{78}$ (Grifos meus)

O direito ao meio ambiente ecologicamente equilibrado, no mesmo ano da Conferencia Rio +20 , sofreu uma grave derrota, frente a interesses de um grupo politicamente dominante no Brasil. O Código Florestal vigente ${ }^{79}$ potencializa diversos impactos ambientais, ao reduzir a proteção das áreas de APP e RL, além de anistiar proprietários de terra que não cumpriram com as suas obrigações de preservação ambiental até julho de 2008, mesma data da entrada em vigor do Decreto 6.514, que conferiu maior efetividade à Lei de Crimes Ambientais e ao Código florestal de 1965.

A motivação política da influente bancada ruralista é muito clara, e incentiva o desmatamento, que realmente aumentou. Com a sanção do Código Florestal de 2012, o desmatamento na Amazônia Legal, que vinha apresentando constante queda, passou a aumentar. Apenas em 2016,

\footnotetext{
${ }^{78}$ FIGUEIREDO, Guilherme José Purvin de. Comentários ao Art. $1^{\circ}$ da Lei 12.651 , de 25 de maio de 2012. In: MILARÉ, Édis; MACHADO, Paulo Affonso Leme (Org.). Novo Código Florestal: Comentários à Lei 12.651, de 25 de maio de 2012, à Lei 12.727, de 17 de outubro de 2012 e ao Decreto 7.830, de 17 de outubro de2012. $2^{\mathrm{a}}$ ed. São Paulo: Revista dos Tribunais, 2013. p. 30-32. ${ }^{79}$ A redação de alguns artigos da Lei 12.651/2012 foi alterada pela Medida Provisória ${ }^{\circ}$ 571, de 2012, convertida na Lei $\mathrm{n}^{\circ} 12.727$, de 17 de outubro de 2012; pela Lei $\mathrm{n}^{\circ} 13.295$, de 14 de junho de 2016; e pela Lei $\mathrm{n}^{\circ}$ 13.465, de 11 de julho de 2017. Porém, tais alterações e inclusões de artigos não retiraram a inconstitucionalidade dos 58 artigos questionados pelas Ações Diretas de Inconstitucionalidade.
} 
conforme dados do PRODES/INPE, foram desmatados $7.989 \mathrm{~km} 2$, um aumento de $29 \%$ em relação a $2015^{80}$.

Foram ajuizadas pela Procuradoria-Geral da República as ações diretas de inconstitucionalidade n. 4901, 4902 e 4903 para impugnar dispositivos da Lei 12.651/2012, sendo recebidas pelo STF em 2013. Além delas, há a ADI 4937, de autoria do Partido Socialismo e Liberdade (PSOL) e uma ação declaratória de constitucionalidade (ADC 42), de autoria do Partido Progressista (PP). As cinco ações foram julgadas em conjunto. Como consta na parte "Dos Fatos" da ADI 4901:

Ignorando a clara diretriz constitucional sobre o tema da proteção ambiental, bem como os explícitos mandamentos da Carta da República a respeito da garantia do direito fundamental ao meio ambiente ecologicamente equilibrado, o processo legislativo foi dominado por propostas que tinham como pano de fundo um único objetivo: desonerar os proprietários rurais dos deveres referentes à proteção das florestas e, ainda, "anistiar" ílegalidades antes cometidas. ${ }^{81}$

Entretanto, o Supremo Tribunal Federal, que deveria proteger o direito fundamental ao meio ambiente equilibrado de legislação contrária à Constituição Federal, acabou aceitando a extensa diminuição das regras de proteção ambiental e anistia a quem não cumpriu a legislação anterior. $\mathrm{O}$ resultado do julgamento conjunto será visto mais a frente neste trabalho.

\subsection{Temas abordados nas ADIs}

A PGR dividiu os 58 dispositivos questionados em três ADIs. A 4901 impugnou os artigos $12, \S 4^{\circ}, \S 5^{\circ}, \S 6^{\circ}, \S 7^{\circ}$ e $\S 8^{\circ}$; Art. $13^{\circ}$, $1^{\circ}$; Art. 15; Art. $48, \S 2^{\circ}$; Art. $66, \S 3^{\circ}, \S 5^{\circ}$, II, III e IV e $\S 6^{\circ}$ e o Art. 68, além de requerer interpretação conforme a constituição ao Art. 28. No geral, esses artigos

\footnotetext{
${ }^{80}$ Dados disponíveis em: http://www.inpe.br/noticias/noticia.php?Cod_Noticia=4344. INPE Acesso em 2 jun. 2018. 2 jun. 2018.

${ }^{81}$ STF, ADI n. 4901, Rel. Ministro Luiz Fux, Brasília. Julgamento conjunto no Plenário do STF, concluído em 28 fev. 2018. Petição Inicial ajuizada pelo Ministério Público Federal, em 18 jan. 2013. p. 7.
} 
abordam principalmente a diminuição da proteção das áreas de Reserva Legal.

A ADI 4902 impugna o $\S 3^{\circ}$ do Art. $7^{\circ} ; \S 4^{\circ}$ e $\S 5^{\circ}$ do Art. 59 e artigos 60, 61-A, 61-B, 61-C, 63, 67 e 78-A, que diminuem o padrão de proteção ambiental e até extinguem algumas previsões de espaços territoriais especialmente protegidos ${ }^{82}$. Nela há impugnação da maioria dos artigos que instituem a anistia as sanções de quem não cumpriu o Código Florestal de 1965 antes de julho de 2008.

A ADI 4903, por fim, pede a inconstitucionalidade do Art. $3^{\circ}$, VIII, alínea "b", IX, XVII, XIX e parágrafo único; $4^{\circ}$, III, IV, $\S 1^{\circ}, \S 4^{\circ}, \S 5^{\circ}, \S 6^{\circ}$; Art. $5^{\circ}$, Art. $8^{\circ}, \S 2^{\circ}$; Art. 11 e Art. 62, principalmente pela diminuição das Áreas de Preservação Permanente. Isso diminui inclusive a proteção de encostas e morros, fundamentais para evitar enxurradas e deslizamentos.

O PSOL ajuizou uma única ação, a ADI 4937. Nela, é requerida a declaração de inconstitucionalidade do Art. 3, VIII, “b”, Art. $7^{\circ}, \S 3^{\circ}$; Art. $13^{\circ}, \S 1^{\circ}$; Art.44; Art. 48, $2^{\circ}$; Art. $59 \S 2^{\circ}, \S 4^{\circ}$ e $\S 5^{\circ}, 60,61-A, 61-B, 61-C$, 63.

Vírginia Totti Guimarães divide a inconstitucionalidade da Lei 12.651/2012 em três pilares:

i) a diminuição das regras de proteção ambiental, por meio da alteração dos critérios técnicos para definição de áreas de preservação permanente, do estabelecimento de exceções ao regime geral de proteção destas áreas e das reservas legais, enfraquecimento do regime de proteção dos apicuns, dentre outros;

ii) a anistia da responsabilidade ambiental nas três esferas: administrativa, criminal e civil. Em destaque, a anistia das obrigações de reparação dos danos ambientais, que se deu pela regularização de atividades que ocorriam em dissonância ao então Código Florestal em vigor (Lei 4.771-1965), com a criação da chamada área rural consolidada, definida como "área de imóvel rural com ocupação antrópica preexistente a 22 de julho de 2008, com edificações, benfeitorias ou atividades agrossilvipastoris, admitida, neste último caso, a adoção do regime de pousio" (Art. $3^{\circ}$, IV, Lei 12.651/2012);

iii) a instrução de um mercado de pagamento por serviços ambientais no Brasil, que serve, inclusive e especialmente, para a regularização destas áreas rurais consolidadas. ${ }^{83}$

\footnotetext{
${ }^{82}$ STF, ADI n. 4902, Rel. Ministro Luiz Fux, Brasília. Julgamento conjunto em Plenário, concluído em 28 fev. 2018. Petição Inicial ajuizada pelo Ministério Público Federal, em jan. 2013

${ }^{83}$ GUIMARÃES, Virgínia Totti. A (in)constitucionalidade do Novo Código Florestal no STF e o $\begin{array}{lllll}\text { voto de } & \text { Luix } & \text { Fux. } & \text { Disponível }\end{array}$
} 
A anistia criada pela área rural consolidada será abordada primeiro, pois é importante para compreender algumas diminuições das regras de proteção ambiental. Não serão abordados todos os artigos que afetam as áreas de APP e RL, mas apenas alguns exemplos para se ter ideia do potencial lesivo do Código Florestal de 2012 para o direito ao meio ambiente ecologicamente equilibrado e os princípios do Direito Ambiental. O "mercado de pagamentos por serviços ambientais no Brasil" também será abordado de forma simplificada, com foco nos pontos em desacordo com a proteção conferida ao meio ambiente pela Constituição Federal e o ordenamento jurídico brasileiro.

\subsubsection{Anistia na esfera administrativa, criminal e civil}

O Código Florestal de 2012 implantou mecanismos de anistia para quem descumpriu a legislação anterior nas chamadas áreas rurais consolidadas, que aparecem pela primeira vez no Art. $3^{\circ}$, IV, da Lei 12.651/2012, sendo definidas como "área de imóvel rural com ocupação antrópica preexistente a 22 de julho de 2008, com edificações, benfeitorias ou atividades agrossilvipastoris, admitida, neste último caso, a adoção do regime de pousio"84. Essas áreas são previstas no Art. 61-A para as APPS e 66 para RL, no capítulo XIII (disposições transitórias), que cria os Programas de Regularização Ambiental (PRAs) ${ }^{85}$.

O proprietário ou possuidor que ingressa nesse programa, enquanto estiver sendo cumprido o termo de compromisso, "não poderá ser autuado por infrações cometidas antes de 22 de julho de 2008", em relação à "supressão irregular de vegetação em Áreas de Preservação Permanente, de

http://justificando.cartacapital.com.br/2017/12/05/inconstitucionalidade-do-novo-codigo-florestalno-stf-e-o-voto-de-luiz-fux/ Acesso em 2 jun. 2018.

\footnotetext{
${ }^{84}$ Art $3^{\circ}$, IV. Lei 12.651 de 25 de maio de 2012.

${ }^{85}$ Art. 59. Lei 12.651 de 25 de maio de 2012.
} 
Reserva Legal e de uso restrito" 86 . As multas serão "consideradas como convertidas em serviços de preservação, melhoria e recuperação da qualidade do meio ambiente, regularizando o uso de áreas rurais consolidadas" ${ }^{\prime 87}$. A assinatura do termo de compromisso dos PRAs suspende "a punibilidade dos crimes previstos nos Arts. 38, 39 e 48 da Lei 9.605/1998 ${ }^{88}$, enquanto o termo estiver sendo cumprido"89. A Lei ainda prevê que a suspensão da pretensão punitiva suspende a prescrição $0^{90}$, e "extingue-se a punibilidade com a efetiva regularização" $"$.

Tais normas consolidam um regime diferenciado, mais benéfico, aos que não cumpriram as previsões da legislação anterior até 22 julho de 2008. Nessa data, entrou em vigor do Decreto $\mathrm{n}^{\circ}$ 6.514, o qual "dispõe sobre as infrações e sanções administrativas ao meio ambiente, estabelece o processo administrativo federal para apuração destas infrações, e dá outras providências", que, ao regulamentar as infrações ambientais previstas na Lei de Crimes Ambientais ${ }^{92}$, daria maior efetividade ao Código Florestal de 1965. É evidente que houve motivação política visando a regularização de ocupações irregulares. ${ }^{93}$ Virgínia Totti Guimaraes entende que as normas do capítulo XIII da Lei 12.651 "não são, na prática, transitórias"94.

\footnotetext{
${ }^{86}$ Art. 59, § 4º Lei 12.651 de 25 de maio de 2012.

${ }^{87}$ Art. 59, § 50. Lei 12.651 de 25 de maio de 2012.

${ }^{88}$ A Lei 9.605/1998 “dispõe sobre as sanções penais e administrativas derivadas de condutas e atividades lesivas ao meio ambiente, e dá outras providências": Art. 38. Destruir ou danificar floresta considerada de preservação permanente, mesmo que em formação, ou utilizá-la com infringência das normas de proteção; Art. 39. Cortar árvores em floresta considerada de preservação permanente, sem permissão da autoridade competente; Art. 48. Impedir ou dificultar a regeneração natural de florestas e demais formas de vegetação.

${ }^{89}$ Art. 60, Lei 12.651 de 25 de maio de 2012.

${ }^{90}$ Art. 60, § $1^{\text {o }}$. Lei 12.651 de 25 de maio de 2012.

${ }^{91}$ Art. 60, § 2 ${ }^{\circ}$. Lei 12.651 de 25 de maio de 2012.

92 LIMA, Letícia Maria Rêgo Teixeira. O novo Código Florestal (LEI 12.651/2012) à luz do princípio da vedação ao retrocesso socioambiental. Trabalho de Conclusão de Curso - Faculdade de Direito, Pontifícia Universidade Católica do Rio de Janeiro, Rio de Janeiro. 2015. Disponível em https://www.maxwell.vrac.puc-rio.br/26087/26087.PDF p. 41.

${ }^{93}$ LIMA, Letícia Maria Rêgo Teixeira. O novo Código Florestal (LEI 12.651/2012) à luz do princípio da vedação ao retrocesso socioambiental. Trabalho de Conclusão de Curso - Faculdade de Direito, Pontifícia Universidade Católica do Rio de Janeiro, Rio de Janeiro. 2015. Disponível em https://www.maxwell.vrac.puc-rio.br/26087/26087.PDF p. 41.

${ }^{94}$ GUIMARÃES, Virgínia Totti. A (in)constitucionalidade do Novo Código Florestal no STF e o voto de Luix $\quad$ Fux. $\quad$ Disponível em http://justificando.cartacapital.com.br/2017/12/05/inconstitucionalidade-do-novo-codigo-florestalno-stf-e-o-voto-de-luiz-fux/ Acesso em 2 jun. 2018.
} 
Ao contrário, elas consolidam um regime diferenciado, mais benéfico, a respeito das restrições ao direito de propriedade, em relação aos que cumpriam com a legislação em 2008. Trata-se de verdadeira quebra da isonomia, utilizando-se como critério o descumprimento da legislação ambiental. ${ }^{95}$

Com a instituição de dois regimes, os proprietários que não cumpriram o Código Florestal de 1965 ganharam o direito de continuar utilizando áreas degradadas, em detrimento dos que obedeceram a Lei e não ampliaram sua produção $^{96}$ além do permitido na legislação. É evidente a injustiça da situação. Letícia Lima descreve os dois regimes gerados pela criação das áreas rurais consolidadas:

Aqueles que a descumpriram a legislação até julho de 2008 não serão punidos e terão obrigações diferenciadas e menos restritivas em relação à recomposição da área; aqueles que cumpriram, ou seja, cujos imóveis não se encontram enquadrados como áreas rurais consolidadas, terão um regime mais rígido e voltado à proteção das áreas de preservação permanente e reservas legais. ${ }^{97}$

Antes da adequação aos PRAs o imóvel deve obrigatoriamente aderir ao Cadastro Ambiental Rural ${ }^{98}$. Esse importante registro é definido no caput do Art. 29 como:

Um registro público eletrônico de âmbito nacional, obrigatório para todos os imóveis rurais, com a finalidade de integrar as informações ambientais das propriedades e posses rurais, compondo base de dados para controle, monitoramento, planejamento ambiental e econômico e combate ao desmatamento. ${ }^{99}$

Apesar de ser um importante avanço, enfrenta atualmente lentidão e falta de estrutura ${ }^{100}$. Desse modo, o prazo para requerer a inscrição no CAR foi prorrogado para 31 de maio de 2018, pelo Decreto 9.257/2017. Assim, os

\footnotetext{
${ }^{95}$ GUIMARÃES, Virgínia Totti. A (in)constitucionalidade do Novo Código Florestal no STF e o voto de Luix Fux. Disponível em http://justificando.cartacapital.com.br/2017/12/05/inconstitucionalidade-do-novo-codigo-florestalno-stf-e-o-voto-de-luiz-fux/ Acesso em 2 jun. 2018.

${ }^{96}$ FIGUEIREDO, Guilherme José Purvin de. Estado de Exceção Ambiental. Disponível em $<$ http://www.oeco.org.br/colunas/guilherme-jose-purvin-de-figueiredo/estado-de-excecaoambiental/> Acesso em 2 jun. 2018.

${ }^{97}$ LIMA, Letícia Maria Rêgo Teixeira. O novo Código Florestal (LEI 12.651/2012) à luz do princípio da vedação ao retrocesso socioambiental. Trabalho de Conclusão de Curso - Faculdade de Direito, Pontifícia Universidade Católica do Rio de Janeiro, Rio de Janeiro. 2015. Disponível em https://www.maxwell.vrac.puc-rio.br/26087/26087.PDF p. 43.

${ }_{98}$ Art. 59, § $2^{\circ}$. Lei 12.651 de 25 de maio de 2012.

${ }^{99}$ Art. 29, caput. Lei 12.651 de 25 de maio de 2012.

${ }^{100}$ ORENSTEIN, José. O que mudou depois de 5 anos da sanção do Novo Código Florestal. Disponível em <https://www.nexojornal.com.br/expresso/2017/05/25/O-que-mudou-depois-de-5anos-da-san\%C3\%A7\%C3\%A3o-do-Novo-C\%C3\%B3digo-Florestal> Acesso em 2 jun. 2018.
} 
PRAs e os mecanismos de incentivo econômico do Poder Público para auxiliar os proprietários na restauração de APP e RL ainda estão sendo regulamentados e implementados ${ }^{101}$.

\subsubsection{Diminuição de Áreas de Preservação Permanente (APP) e Reserva Legal (RL)}

Muitas unidades de conservação deixaram de ser criadas em áreas de grande importância pois já estavam protegidas pelos institutos de APPs e RLs, que terão sua proteção ambiental reduzida significativamente ${ }^{102}$. A Lei 12.651/2012 define Área de Preservação Permanente (APP) e Reserva Legal (RL) como:

Art. 3o Para os efeitos desta Lei, entende-se por:

II - Área de Preservação Permanente - APP: área protegida, coberta ou não por vegetação nativa, com a função ambiental de preservar os recursos hídricos, a paisagem, a estabilidade geológica e a biodiversidade, facilitar o fluxo gênico de fauna e flora, proteger o solo e assegurar o bem-estar das populações humanas;

III - Reserva Legal: área localizada no interior de uma propriedade ou posse rural, delimitada nos termos do Art. 12, com a função de assegurar o uso econômico de modo sustentável dos recursos naturais do imóvel rural, auxiliar a conservação e a reabilitação dos processos ecológicos e promover a conservação da biodiversidade, bem como o abrigo e a proteção de fauna silvestre e da flora nativa. ${ }^{103}$

As APPs são importantes, desse modo, para: a proteção de vegetação situada em margens de corpos hídricos e nascentes; prevenção de deslizamentos e enxurradas, devido à sua capacidade de proteger encostas e topos de morro; evitar o assoreamento e erosão; e a própria preservação dos recursos hídricos, como os aquíferos. Já as RL são importantes para assegurar os processos ecológicos essenciais e conservar a biodiversidade, servindo de

\footnotetext{
${ }^{101}$ GUIDOTTI, Vinicius et al.. Números detalhados do Novo Código Florestal e suas implicações para os PRAs: Sustentabilidade em debate, Número 5. SP: Imaflora, 2017. Disponível em <http://www.imaflora.org/downloads/biblioteca/5925cada05b49_SUSTemDEB_low_web_links.p df> Acesso em 2 jun. 2018. p. 2.

${ }^{102}$ GUIMARÃES, Virgínia Totti. A (in)constitucionalidade do Novo Código Florestal no STF e o voto de Luix Fux. Disponível em http://justificando.cartacapital.com.br/2017/12/05/inconstitucionalidade-do-novo-codigo-florestalno-stf-e-o-voto-de-luiz-fux/ Acesso em 2 jun. 2018.

${ }^{103}$ Art. $3^{\circ}$. Lei 12.651 de 25 de maio de 2012.
} 
abrigo para a fauna e a flora nativas, como o próprio Código Florestal de 2012 deixa claro. Conforme o Art. 12, I e II de tal Lei, os imóveis rurais devem manter área com cobertura de vegetação nativa, a título de RL, sem prejuízo da aplicação das normas sobre as APPs, respeitando os seguintes percentuais: Na Amazônia Legal, 80\% em área de floresta, 35\% em área de Cerrado, e 20\% em áreas de "campos gerais"; nas demais regiões do país o percentual é de apenas $20 \%$, incluindo o Cerrado, crucial para a manutenção dos recursos hídricos e biodiversidade brasileira, mas pouco protegido e muito devastado.

A comunidade cientifica, nos debates que antecederam a aprovação do Código Florestal atualmente vigente, analisou e defendeu ferrenhamente a importância das APPs e RLs para a garantia de um meio ambiente ecologicamente equilibrado e capaz de abordar as previsões do Art. 225 da $\mathrm{CF} / 88$. Dentre elas, há a vedação de qualquer utilização que comprometa a integridade dos atributos que justificam a proteção dos espaços territoriais especialmente protegidos ${ }^{104}$. Porém, tal artigo foi desrespeitado. O Poder Legislativo atendeu cegamente aos interesses agronegócio na confecção do atual Código Florestal, alterando dispositivos do Código de 1965 de modo a comprometer tais atributos, como será visto. As ADIs 4901, 4902 e 4903 contém um importante documento elaborado pela comunidade cientifica brasileira, "O Código Florestal e a Ciência: Contribuições para o diálogo", de autoria da Sociedade Brasileira para o Progresso da Ciência (SBPC) e Academia Brasileira de Ciências (ABC), que elucida a importância e atributos das APPs:

Entre os pesquisadores, há consenso de que as áreas marginais a corpos d'água - sejam elas várzeas ou florestas ripárias - e os topos de morro ocupados por campos de altitude ou rupestres são áreas insubstituíveis em razão da biodiversidade e de seu alto grau de especialização e endemismo, além dos serviços ecossistêmicos essenciais que desempenham - tais como a regularização hidrológica, a estabilização de encostas, a manutenção da população de polinizadores e de ictiofauna, o controle natural de pragas, das doenças e das espécies exóticas invasoras. Na zona ripária, além do abrigo da biodiversidade com seu provimento de serviços ambientais, os solos úmidos e sua vegetação nas zonas de influência de rios e lagos são ecossistemas de

\footnotetext{
${ }^{104}$ Art. 225, § 1º III. Constituição da República Federativa do Brasil de 1988.
} 
reconhecida importância na atenuação de cheias e vazantes, na redução da erosão superficial, no condicionamento da qualidade da água e na manutenção de canais pela proteção de margens e redução do assoreamento. Existe amplo consenso científico de que são ecossistemas que, para sua estabilidade e funcionalidade, precisam ser conservados ou restaurados, se historicamente degradados. Quando ecossistemas naturais maduros ladeiam os corpos d'água e cobrem os terrenos com solos hídromórficos associados, o carbono e os sedimentos são fixados, a água em excesso é contida, a energia erosiva de correntezas é dissipada e os fluxos de nutrientes nas águas de percolação passam por filtragem química e por processamento microbiológico, o que reduz sua turbidez e aumenta sua pureza. ${ }^{105}$ (Grifos meus)

As áreas de RL têm importância e objetivo diferente das APPs. As primeiras visam principalmente a proteção da fauna e flora nativa, como esclarece a comunidade científica por meio do mesmo documento:

\begin{abstract}
A Reserva Legal tem funções ambientais e características biológicas distintas das APPs em termos da composição e estrutura de sua biota. Na Amazônia, a redução das RLs diminuiria a cobertura florestal para níveis que comprometeriam a continuidade física da floresta devido a prováveis alterações climáticas. Portanto, a redução de RLs aumentaria significativamente o risco de extinção de espécies e comprometeria a efetividade dessas áreas como ecossistemas funcionais e seus serviços ecossistêmicos e ambientais.
\end{abstract}

Nos biomas com índices maiores de antropização, como o Cerrado, a Caatinga e algumas área altamente fragmentadas como, a Mata Atlântica e partes da Amazônia, os remanescentes de vegetação nativa, mesmo que pequenos, têm importante papel na conservação da biodiversidade e na diminuição do isolamento dos poucos fragmentos da paisagem. Tais remanescentes funcionam como trampolins ecológicos no deslocamento e na dispersão das espécies pela paisagem. Essas características exigem que eventuais compensações sejam feitas na própria microbacia ou na bacia hidrográfica. As características fitoecológicas da área a ser compensada - e não o bioma como um todo, devido à alta hererogeneidade de formações vegetais dentro de cada bioma - devem ser a referência para a compensação.

A restauração das áreas de $R L$, viável graças ao avanço do conhecimento cientifico e tecnológico, deve ser feita preferencialmente com espécies nativas, pois o uso de espécies exóticas compromete sua função de conservação da biodiversidade e não assegura a restauração de suas funções ecológicas e dos serviços ecossistêmicos. O uso de espécies exóticas pode ser admitido, mas na condição de pioneiras, conforme a legislação vigente. É na Reserva Legal que se constata o maior passivo ambiental do setor agropecuário brasileiro. Novas técnicas de restauração da RL usando as áreas de menor aptidão agrícola e incorporando o conceito de manejo sustentável de espécies nativas para a produção de madeiras e fibras, de medicinais, de frutíferas nativas e outras permitidas pela legislação são alternativas viáveis de diversificação de produção com retorno econômico significativo. ${ }^{106}$ (grifos meus)

105 SILVA, José Antonio Aleixo da et al.. O Código Florestal e a Ciência: Contribuições para o Diálogo. São Paulo: Sociedade Brasileira para o Progresso da Ciência, SBPC; Academia Brasileira de Ciências, ABC, 2011. p. 12

106 SILVA, José Antonio Aleixo da et al.. O Código Florestal e a Ciência: Contribuições para o Diálogo. p. 13 
Conforme esclarecido pelo trecho citado da obra "O Código Florestal e a Ciência: Contribuições para o diálogo", as eventuais compensações de RL devem ser feitas na própria microbacia ou bacia hidrográfica da propriedade que apresenta déficit de vegetação nativa, devido à alta diferença de formações vegetais dentro de um mesmo bioma. Os artigos $48, \S 2^{\circ}$ e $66, \S 5^{\circ}$, II, III e IV e $\S 6^{\circ}$ do Novo Código Florestal, porém, permitem a compensação no mesmo bioma, em lugares muito distantes da área que tem déficit de RL, até mesmo em outros Estados. No Código Florestal de 1965, conforme redação do Art. 44, III, isso deveria ocorrer na mesma microbacia, demonstrando maior preocupação da lei anterior com os processos ecológicos essenciais e a biodiversidade. ${ }^{107}$

Como a própria comunidade científica esclarece, APPs e RLs têm papeis diferentes a desempenhar, mas igualmente importantes. O Art. 15 da lei 12.651/12, contrariando tal diferença, permite o cômputo das APPs no cálculo do percentual da RL do imóvel ${ }^{108}$ em áreas rurais consolidadas, diminuindo a proteção necessária para a manutenção dos processos ecológicos essenciais e abrigo da fauna e flora. O Art. 13 prevê hipótese em que o percentual de RL em imóvel situado na Amazônia Legal pode ser reduzido de $80 \%$ para 50\%. O Art. 67 prossegue com o regime diferenciado, prevendo que os imóveis que possuíam no máximo 4 módulos fiscais ${ }^{109} \mathrm{em}$ 22 de julho de 2008 terão sua RL constituída apenas pela vegetação nativa remanescente até essa data. Já nas APPs, conforme redação do Art. 61-A, é

\footnotetext{
${ }^{107}$ LIMA, Letícia Maria Rêgo Teixeira. O novo Código Florestal (LEI 12.651/2012) à luz do princípio da vedação ao retrocesso socioambiental. Trabalho de Conclusão de Curso - Faculdade de Direito, Pontifícia Universidade Católica do Rio de Janeiro, Rio de Janeiro. 2015. Disponível em https://www.maxwell.vrac.puc-rio.br/26087/26087.PDF p. 69.

${ }_{108}$ Art. 15. Lei 12.651 de 25 de maio de 2012.

109 "Módulo fiscal é uma unidade de medida, em hectares, cujo valor é fixado pelo INCRA para cada município onde está localizada a propriedade, e no Brasil varia de 5 a 110 hectares, levandose em conta: “(a) o tipo de exploração predominante no município (hortifrutigranjeira, cultura permanente, cultura temporária, pecuária ou florestal); (b) a renda obtida no tipo de exploração predominante; (c) outras explorações existentes no município que, embora não predominantes, sejam expressivas em função da renda ou da área utilizada; (d) o conceito de "propriedade familiar"', conforme definição da EMBRAPA, disponível em <https://www.embrapa.br/codigoflorestal/area-de-reserva-legal-arl/modulo-fiscal> Acesso em 2 jun. 2018.
} 
autorizada a "continuidade das atividades agrossilvipastoris, de ecoturismo e de turismo rural em áreas rurais consolidadas até 22 de julho de 2008 ".

É evidente que a anistia criada áreas rurais consolidadas é diretamente responsável por considerável parte da diminuição da proteção de APP e RL. O passivo que deveria ser reconstituído de Áreas de Preservação Permanente foi reduzido em 4,5 milhões de hectares e o de Reserva Legal em 36,5 milhões de ha, conforme pesquisa ${ }^{110}$ elaborada pelo IMAFLORA. Essa é a diminuição causada apenas pelos mecanismos de anistia definidos nos artigos mencionados acima (13, 15 e 67 para as RLs e 61-A para as APPs hídricas) ${ }^{111}$.

Os dados apresentados mostram a perda gerada apenas por tais artigos, mas a descaracterização da função da RL e APP e diminuição do passivo que deveria ser reconstituído vai muito além. Isso será mostrado na tabela com os resultados do julgamento no STF, que descreve o impacto dos demais artigos. O próprio Art. $4^{\circ}$, que delimita em rol taxativo as áreas consideradas APP, é um enorme retrocesso em relação ao Código Florestal de 1965. Dois pontos em particular sobre as APPs são manifestamente contrários ao princípio da prevenção, precaução e vedação ao retrocesso socioambiental:

O primeiro é definido no Art. 4, I e nos parágrafos e inciso II do Art. 61-A. Por meio de tais dispositivos, as faixas de medição de APP serão contadas a partir da borda da calha do leito regular do curso d'água, e não a partir do nível mais alto, como no Código Florestal anterior (Art. 20 "a" Lei $4.771 / 1965)^{112}$. Esse retrocesso pode favorecer inundações e tragédias, que não estarão sendo prevenidas corretamente, além de reduzir

\footnotetext{
${ }^{110}$ GUIDOTTI, Vinicius et al. Números detalhados do Novo Código Florestal e suas implicações para os PRAs: Sustentabilidade em debate, Número 5. SP: Imaflora, 2017. Disponível em <http://www.imaflora.org/downloads/biblioteca/5925cada05b49_SUSTemDEB_low_web_links.p df> Acesso em 2 jun. 2018. p. 1

${ }^{111}$ GUIDOTTI, Vinicius et al. Números detalhados do Novo Código Florestal e suas implicações para os PRAs: Sustentabilidade em debate, Número 5. SP: Imaflora, 2017. Disponível em <http://www.imaflora.org/downloads/biblioteca/5925cada05b49_SUSTemDEB_low_web_links.p df $>$ Acesso em 2 jun. 2018. p. 2.

${ }^{112}$ LIMA, Letícia Maria Rêgo Teixeira. O novo Código Florestal (LEI 12.651/2012) à luz do princípio da vedação ao retrocesso socioambiental. Trabalho de Conclusão de Curso - Faculdade de Direito, Pontifícia Universidade Católica do Rio de Janeiro, Rio de Janeiro. 2015. Disponível em https://www.maxwell.vrac.puc-rio.br/26087/26087.PDF p. 48.
} 
significativamente a proteção dessas áreas, como alertou a comunidade científica:

Uma possível alteração na definição da APP ripária, do nível mais alto do curso d'água - conforme determina o Código Florestal vigente - para a borda do leito menor, como é proposto no substitutivo, representaria grande perda de proteção para áreas sensíveis. Essa alteração proposta no bordo de referência significaria perda de até $60 \%$ de proteção para essas áreas na Amazônia, por exemplo. Já a redução da faixa ripária de 30 para $15 \mathrm{~m}$ nos rios com até $5 \mathrm{~m}$ de largura, que compõem mais de $50 \%$ da rede de drenagem em extensão, resultaria numa redução de $31 \%$ na área protegida pelas APPs ripárias. Estudo recente constatou que as APPs ripárias representam, de acordo com o Código em vigor, somente $6,9 \%$ das áreas privadas. ${ }^{113}$

Conforme Guilherme José Purvin de Figueiredo, os relevos de baixa declividade, amplamente afetados por essa mudança, são exatamente "as áreas mais cobiçadas para monocultura e pecuária extensiva" ${ }^{114}$. Letícia Lima, ainda no ponto relativo às APPs, desperta atenção para a medição da largura da APP a partir do tamanho do imóvel nas áreas rurais consolidadas, e não a partir da largura do curso d'água:

A largura dependerá do tamanho do imóvel - medido em módulos fiscais - e não de acordo com a largura do curso d'água, o que, técnica e cientificamente, não faz sentido, diminui drasticamente a cobertura das áreas frágeis que devem ser protegidas. Dessa forma, as APP ao longo de um mesmo rio serão completamente dessemelhantes, dificultando a formação dos corredores ecológicos e o endemismo esperado da área em questão. ${ }^{115}$

O segundo ponto relativo às APPs que é alarmantemente contrário aos princípios da prevenção, precaução, vedação ao retrocesso, ao Art. 225 e a outros artigos da Constituição Federal que visam garantir uma vida sadia e digna é o Art. 63 do Código Florestal de 2012. Tal artigo versa sobre as áreas rurais consolidadas nos locais de que tratam os incisos V, VIII, IX e X do Art. 4을 áreas de encostas com declive superior a 45 graus; bordas de

\footnotetext{
${ }^{113}$ SILVA, José Antonio Aleixo da et al.. O Código Florestal e a Ciência: Contribuições para o Diálogo. p. 12-13

114 FIGUEIREDO, Guilherme José Purvin de. Estado de Exceção Ambiental. Disponível em $<$ http://www.oeco.org.br/colunas/guilherme-jose-purvin-de-figueiredo/estado-de-excecaoambiental/> Acesso em 2 jun. 2018.

${ }^{115}$ LIMA, Letícia Maria Rêgo Teixeira. O novo Código Florestal (LEI 12.651/2012) à luz do princípio da vedação ao retrocesso socioambiental. Trabalho de Conclusão de Curso - Faculdade de Direito, Pontifícia Universidade Católica do Rio de Janeiro, Rio de Janeiro. 2015. Disponível em https://www.maxwell.vrac.puc-rio.br/26087/26087.PDF p. 49 e 50.
} 
tabuleiros e chapadas; topos de morros, montes, montanhas e serras; e áreas com altitude superior a 1.800 metros.

Art. 63. Nas áreas rurais consolidadas nos locais de que tratam os incisos V, VIII, IX e X do Art. 4º, será admitida a manutenção de atividades florestais, culturas de espécies lenhosas, perenes ou de ciclo longo, bem como da infraestrutura física associada ao desenvolvimento de atividades agrossilvipastoris, vedada a conversão de novas áreas para uso alternativo do solo.

Esse artigo é um dos maiores exemplos da frieza da bancada ruralista, visto que o desmatamento da vegetação nativa de encostas e topos de morro é causa frequente de desastres envolvendo erosões, deslizamentos e enxurradas. O exemplo mais notório é a tragédia de 2011 na Região Serrana do Rio de Janeiro, que gerou 918 mortes conforme dados oficiais (o número real é muito maior), e milhares de pessoas afetadas ${ }^{116}$. Estudo ${ }^{117}$ organizado pelo Ministério do Meio Ambiente (MMA), com participação do ICMBio e da Aeronáutica, analisou a tragédia:

Diante das inúmeras tragédias relacionadas a enchentes, deslizamentos de terra e rochas que vem ocorrendo cada vez com maior frequência e intensidade, atingindo centenas de cidades, milhões de brasileiros e deixando um rastro de milhares de vítimas fatais, além de prejuízos econômicos imensuráveis, é necessário fazer uma análise isenta e responsável sobre as ações a serem tomadas e que podem minimizar ou agravar a situação em caso de eventos climáticos extremos, seja no futuro imediato e no longo prazo. ${ }^{118}$

O amplo estudo incluiu análises acerca do papel das Áreas de Preservação Permanente previstas no Código Florestal de 1965 e das Unidades de Conservação na diminuição dessas tragédias. Após analisar a relação da legislação ambiental com os desastres relacionados a enchentes e

\footnotetext{
${ }^{116}$ CANEJO, Andressa. $\mathrm{N}^{\mathrm{O}}$ de vítimas em tragédia no RJ pode ser 10 vezes maior, diz entidade. Disponível em http://g1.globo.com/rj/regiao-serrana/noticia/2015/08/entidades-apontamsubnotificacao-de-vitimas-da-tragedia-de-2011-na-serra.html Acesso em 2 jun. 2018.

${ }^{117}$ SCHÄFFER, Wigold Bertoldo et al.. Áreas de Preservação Permanente e Unidades de Conservação \& Áreas de Risco: O que uma coisa tem a ver com a outra? Relatório de Inspeção da área atingida pela tragédia das chuvas na Região Serrana do Rio de Janeiro. Brasília: MMA, 2011. Disponível

em

〈http://www.mma.gov.br/estruturas/202/_publicacao/202_publicacao01082011112029.pdf> Acesso em 2 jun. 2018.

${ }^{118}$ SCHÄFFER, Wigold Bertoldo et al.. Áreas de Preservação Permanente e Unidades de Conservação \& Áreas de Risco: O que uma coisa tem a ver com a outra? Relatório de Inspeção da área atingida pela tragédia das chuvas na Região Serrana do Rio de Janeiro. Brasília: MMA, 2011. Disponível em 〈http://www.mma.gov.br/estruturas/202/_publicacao/202_publicacao01082011112029.pdf〉 Acesso em 2 jun. 2018. p. 31.
} 
deslizamentos de terra, que deveriam ser prevenidas por tais normas, concluiu:

O Desastre natural ocorrido na região serrana do Rio de Janeiro assume contorno catastrófico por conta da conjugação de fatores sabidamente associados à geração de risco de acidentes naturais. A topografia, geologia, hidrografia e regime pluviométrico da região determinam a previsibilidade da ocorrência de acidentes naturais na área, fenômenos diretamente associados com a evolução e moldagem da paisagem. Nessas condições a suscetibilidade a escorregamentos associados à instabilidade de encostas é bastante evidente, e a ocupação destas encostas e áreas adjacentes torna os desastres naturais em eventos catastróficos devido a proporção de vítimas e danos socioeconômicos de elevada monta.

$O$ presente estudo demonstra que a faixa de 30 metros em cada margem (60 metros no total) considerada Área de Preservação Permanente ao longo dos cursos d'água estivesse livre para a passagem da água, bem como, se as áreas com elevada inclinação e os topos de morros, montes, montanhas e serras estivessem livres da ocupação e intervenções inadequadas, como determina o Código Florestal, os efeitos da chuva teriam sido significativamente menores. [...]

As áreas diretamente mais afetadas são aquelas definidas pelo Código Florestal como Áreas de Preservação Permanente - APPs [...].

Registrou-se também que em áreas com florestas bem conservadas, livres de intervenções como estradas, edificações ou queimadas, o número de deslizamentos é muito menor do que nas áreas com intervenções e, obviamente, as consequências em termos de perdas materiais e humanas são nulas $[\ldots]$.

Conclui-se, por último, que os parâmetros de preservação permanente estabelecidos no Código Florestal devem ser mantidos e rigorosamente fiscalizados e implementados, tanto nas áreas rurais quanto urbanas. Além disso, a legislação federal deveria ser mais incisiva no sentido de exigir do Poder Público (Federal, Estadual e Municipal) medidas complementares de proteção a áreas que apresentem localmente características ambientais relevantes ou áreas que estejam sujeitas a riscos de enchentes, erosão ou deslizamento de terra e rolamento de rochas. ${ }^{119}$ (grifos meus)

O Código Florestal de 2012, em total oposição ao que foi recomendado, diminuiu consideravelmente a proteção das APPs, e consolidou o desmatamento de vegetação nativa em encostas e morros. Com as conclusões do estudo acima, fica claro que o Código Florestal atualmente vigente não é apenas uma afronta à Constituição Federal e aos princípios norteadores do Direito Ambiental, mas também um desrespeito com à própria vida humana e todos que se esforçam para evitar mais tragédias no Brasil. O

119 SCHÄFFER, Wigold Bertoldo et al.. Áreas de Preservação Permanente e Unidades de Conservação \& Áreas de Risco: O que uma coisa tem a ver com a outra? Relatório de Inspeção da área atingida pela tragédia das chuvas na Região Serrana do Rio de Janeiro. Brasília: MMA, 2011. Disponível em <http://www.mma.gov.br/estruturas/202/_publicacao/202_publicacao01082011112029.pdf> Acesso em 2 jun. 2018. p. 89 e 90. 
núcleo fundamental do direito ao meio ambiente ecologicamente equilibrado, assim, sofreu um ataque alarmante.

O desrespeito aos princípios da prevenção, precaução e vedação ao retrocesso do Código Florestal de 2012 são facilmente constatáveis pelo exemplo do Art. 63. Além disso, não há meio ambiente ecologicamente equilibrado com deslizamentos evitáveis por medidas preventivas do Poder Público. Não há solidariedade intergeracional quando as futuras gerações perdem a vida em desastres potencializados pela ação e omissão humana. $\mathrm{O}$ Art. 63, assim como quase todos os dispositivos que diminuem a proteção de espaços territorialmente protegidos, teve a sua constitucionalidade reconhecida pelo Supremo Tribunal Federal (vencidos os Ministros Marco Aurélio, Cármen Lúcia, Rosa Weber e Ricardo Lewandowski).

\subsubsection{Pagamento por serviços ambientais e Cota de Reserva Ambiental}

O capítulo X da Lei 12.651/2012, “do programa de apoio e incentivo à preservação e recuperação do meio ambiente", institui, no Art. 41, o pagamento por serviços ambientais (PSA). O inciso I prevê expressamente essa figura, definida como sendo o "pagamento ou incentivo a serviços ambientais como retribuição, monetária ou não, às atividades de conservação e melhoria dos ecossistemas e que gerem serviços ambientais", exemplificando as atividades em oito alíneas ${ }^{120}$.

\footnotetext{
${ }^{120}$ Art. 41. É o Poder Executivo federal autorizado a instituir, sem prejuízo do cumprimento da legislação ambiental, programa de apoio e incentivo à conservação do meio ambiente, bem como para adoção de tecnologias e boas práticas que conciliem a produtividade agropecuária e florestal, com redução dos impactos ambientais, como forma de promoção do desenvolvimento ecologicamente sustentável, observados sempre os critérios de progressividade, abrangendo as seguintes categorias e linhas de ação: I - pagamento ou incentivo a serviços ambientais como retribuição, monetária ou não, às atividades de conservação e melhoria dos ecossistemas e que gerem serviços ambientais, tais como, isolada ou cumulativamente:

a) o sequestro, a conservação, a manutenção e o aumento do estoque e a diminuição do fluxo de carbono; b) a conservação da beleza cênica natural; c) a conservação da biodiversidade; d) a conservação das águas e dos serviços hídricos; e) a regulação do clima; f) a valorização cultural e
} 
No inciso II, estão previstas as formas de "compensação pelas medidas de conservação ambiental"121. Isso inclui, na alínea "d", a destinação de parte dos recursos arrecadados com a cobrança pelo uso da água (dinheiro público) para a recomposição de Reserva Legal. O já mencionado Art. 66 § 3 permite que, em área rural consolidada, possa haver o plantio de espécies exóticas em $50 \%$ de tal recomposição. Essa possibilidade, assim, desvirtua o objetivo do PSA de incentivar a preservação e recuperação do meio ambiente, como esclarece Juliana Chermont, em monografia sobre "Os pagamentos por serviços ambientais e a cota de reserva ambiental no Código Florestal de 2012":

Apesar das políticas de PSA terem como bandeira a retribuição e recompensa ao agente de preservação ambiental, o Art. 66 § 30 desvirtua totalmente esse objetivo, em contramão inclusive do princípio do protetor-recebedor e do poluidorpagador, ao desviar o objetivo da recuperação das áreas de reserva legal, santuário da mata nativa dentro das propriedades privadas, para a possibilidade de plantio de espécies exóticas e a utilização de dinheiro público para financiar essas práticas. Da forma com que essa política se apresenta, o proprietário só ganha, enquanto toda a coletividade perde. Além disso, a sociedade brasileira, sem ao menos saber, financiará um possível agravamento da crise ambiental. ${ }^{122}$

Tais espécies exóticas podem incluir plantas que geram lucro, como silviculturas e fruticulturas, tornando a situação ainda mais benéfica para quem desmatou antes de 22.07.2008. O Art. $66 \S 3^{\circ}$, desse modo, é notoriamente inconstitucional, violando os princípios expressamente previstos no Art. 225 da Constituição Federal, a função socioambiental da propriedade e os princípios da prevenção e precaução, poluidor-pagador e vedação ao retrocesso socioambiental.

Outra figura instituída pelo Código Florestal de 2012 que contribui para o enfraquecimento das áreas de Reserva Legal é a Cota de Reserva Ambiental (CRA), título nominativo que representa área com vegetação

\footnotetext{
do conhecimento tradicional ecossistêmico; g) a conservação e o melhoramento do solo; h) a manutenção de Áreas de Preservação Permanente, de Reserva Legal e de uso restrito.

${ }^{121}$ Art. 41, II. Lei 12.651 de 25 de maio de 2012.

${ }^{122}$ LOPES, Juliana Chermont Pessoa. Os pagamentos por serviços ambientais e a cota de reserva ambiental no Código Florestal de 2012. Trabalho de Conclusão de Curso - Faculdade de Direito, Pontifícia Universidade Católica do Rio de Janeiro, Rio de Janeiro. 2017. Disponível em https://www.maxwell.vrac.puc-rio.br/31432/31432.PDF p. 48.
} 
nativa, existente ou em processo de recuperação ${ }^{123}$. Tais títulos poderão ser transferidos onerosa ou gratuitamente, e até negociados na bolsa de valores ou balcão organizado ${ }^{124}$.

Os artigos $48, \S 2^{\circ}$ e $66, \S 5^{\circ}$, II, III e IV e $\S 6^{\circ}$ permitem que os proprietários com RL excedente possam emitir CRA, e quem tem déficit de RL poderia compensá-lo comprando tal título de imóveis situados no mesmo bioma ${ }^{125}$. Essa previsão ignora totalmente o fato de um mesmo bioma apresentar grande heterogeneidade.

A flora e fauna locais serão prejudicadas, assim como a vegetação nativa, visto que o problema do desmatamento em determinado local não será resolvido. $\mathrm{O}$ artigo 66 prevê outras formas de compensação, menos acessíveis que os CRA, mas com base no mesmo critério do bioma, que é muito amplo e descaracteriza a proteção das áreas de RL.

Pelo exposto ao longo deste capítulo do presente trabalho, foram exemplificados os temas abordados nas ADIs 4901, 4902, 4903 e 4937, além da ADC 42. Mais artigos serão exemplificados na tabela que consta no capítulo relativo ao julgamento conjunto das ações no Plenário do STF. Contudo, poucos exemplos já são suficientes para demonstrar que o Código Florestal de 2012 possui diversos retrocessos em relação à legislação anterior, atingindo diretamente o núcleo essencial do direito ao meio ambiente ecologicamente equilibrado, principalmente com a descaracterização da proteção de APP e RL. Já foram citados, neste trabalho, alguns argumentos dos autores das ADIs a favor da declaração de inconstitucionalidade dos dispositivos da Lei 12.651/2012, mas serão vistos

\footnotetext{
${ }^{123}$ Art. 44. É instituída a Cota de Reserva Ambiental - CRA, título nominativo representativo de área com vegetação nativa, existente ou em processo de recuperação. Lei 12.651 de 25 de maio de 2012.

${ }^{124}$ MORAIS, Roberta Jardim de; GUETTA, Maurício. Comentários à Cota de Reserva Ambiental. In: MILARÉ, Édis; MACHADO, Paulo Affonso Leme (Org.). Novo Código Florestal: Comentários à Lei 12.651, de 25 de maio de 2012, à Lei 12.727, de 17 de outubro de 2012 e ao Decreto 7.830, de 17 de outubro de2012. $2^{\mathrm{a}}$ ed. São Paulo: Revista dos Tribunais, 2013. p. 359, 360.

${ }^{125}$ CHIAVARI, Joana; LOPES, Cristina Leme. Decisão do STF sobre o Novo Código Florestal enfraquece a Cota de Reserva Ambiental. Disponível em $<$ http://www.oeco.org.br/colunas/colunistas-convidados/decisao-do-stf-sobre-o-novo-codigoflorestal-enfraquece-a-cota-de-reserva-ambiental/> Acesso em 2 jun. 2018.
} 
no capítulo seguinte os argumentos utilizados nas falas que ocorreram no próprio julgamento. Serão mencionados, também, os argumentos a favor da ADC. 


\section{JULGAMENTO CONJUNTO NO SUPREMO TRIBUNAL FEDERAL}

\subsection{Argumentos dos autores}

Passados mais de 5 anos da aprovação do Novo Código Florestal, no dia 14 de setembro de 2017, o STF iniciou o julgamento conjunto das ações quatro ações. Assim, os autores das ADIs 4901, 4902, 4903, 4937 e ADC 42 novamente apresentaram seus argumentos.

O advogado André Maimoni, em nome do PSOL, defendeu que a lei viola os princípios de responsabilidade e solidariedade intergeracional, além de flexibilizar e fragilizar o sistema ambiental. O principal ponto apontado como inconstitucional pelo advogado é a extensa anistia aos produtores rurais que desmataram ilegalmente ${ }^{126}$.

O vice-procurador-geral da República, Nicolau Dino, expôs a posição da PGR, também bastante crítica à lei, que seria incapaz de conciliar os dois preceitos constitucionais fundamentais de preservação ambiental e desenvolvimento sustentável. Criticou principalmente a flexibilização das regras referentes às áreas de APP e RL, além da anistia aos responsáveis por desmatamento ilegal ocorrido antes de 22 de julho de 2008. Os dispositivos que consolidam áreas desmatadas, conforme a PGR, violariam a proteção ambiental e reparação de danos prevista na Constituição Federal. O viceprocurador-geral da República mencionou, para embasar sua opinião, a sustentabilidade ambiental, a função ecológica da reserva legal e ilegalidade de sua recomposição com espécies exóticas, defendendo que a Constituição promove "direito de propriedade ambientalmente qualificado" 127.

\footnotetext{
${ }^{126}$ STF, ADIs n. 4901, 4902, 4903, 4937 e ADC n. 42, Rel. Ministro Luiz Fux, Brasília. Julgamento conjunto no Plenário do STF, concluído em 28 fev. 2018.2018

${ }^{127}$ STF, ADIs n. 4901, 4902, 4903, 4937 e ADC n. 42, Rel. Ministro Luiz Fux, Brasília. Julgamento conjunto no Plenário do STF, concluído em 28 fev. 2018.
} 
Em contrapartida, o representante do PP, Rudy Maia Ferraz, e a ministra da Advocacia-Geral da União, Grace Maria Fernandes, defenderam a constitucionalidade dos artigos do Novo Código Florestal. Ambos defendem que, a partir do paradigma do desenvolvimento sustentável, a lei promove uma conciliação entre os interesses de preservação ambiental e desenvolvimento nacional. Para o representante do PP, a norma faz a composição entre pontos antagônicos, e traz previsibilidade e segurança jurídica, permitindo maior controle sobre os remanescentes de Mata Atlântica e Cerrado. A AGU defende um argumento popular entre ruralistas a favor da constitucionalidade do Código Florestal de 2012, de que não há qualquer anistia, pois só haveria a conversão de multa pecuniária em prestação de serviços ambientais com o cumprimento integral da reparação pactuada. Tal tratamento diferenciado para os agricultores estimularia a recuperação ambiental, que é obrigatória. Segundo a ministra, a redução de RL ocorre apenas na Amazônia Legal, e apenas se o município já tiver pelo menos $50 \%$ de sua área protegida (por unidade de conservação ou reserva indígena). ${ }^{128}$

\subsection{Voto do Relator}

O Ministro Relator Luiz Fux apresentou seu voto ao Plenário do STF no dia 08.11.17. Diante da grande quantidade de dispositivos a serem apreciados, dividiu a leitura do voto em 22 pontos que agrupam os artigos em discussão, declarando a inconstitucionalidade de apenas três itens ${ }^{129}$ que impactam negativamente o meio ambiente.

\footnotetext{
${ }^{128}$ STF, ADIs n. 4901, 4902, 4903, 4937 e ADC n. 42, Rel. Ministro Luiz Fux, Brasília. Julgamento conjunto no Plenário do STF, concluído em 28 fev. 2018.

${ }^{129}$ SOUZA, Oswaldo Braga. Relator rejeita a anistia a multas ambientais em julgamento do Código Florestal no STF. Disponível em https://www.socioambiental.org/pt-br/noticiassocioambientais/relator-rejeita-anistia-a-multas-ambientais-em-julgamento-do-codigo-florestal-nostf Acesso em 2 jun. 2018.
} 
$\mathrm{O} 1^{\circ}$ tema analisado por Fux versa sobre o Art. $3^{\circ}$, VIII, IX, que prevê a intervenção em APP em caso de utilidade pública (VIII) e interesse social (IX), previstas em 12 alíneas que incluem diversas atividades e instalações. Foi concedida interpretação conforme a Constituição, "de modo a se condicionar a intervenção excepcional em APP por interesse social e utilidade pública à inexistência de alternativa técnica ou locacional" "130. No mesmo ponto está incluído o Art. $3^{\circ}$, VIII, b, que teve as expressões "gestão de resíduos" e "instalações necessárias à realização de competições esportivas estaduais, nacionais ou internacionais" declaradas inconstitucionais ${ }^{131}$.

O $2^{\circ}$ ponto abordado abrange o Art. $3^{\circ}$, XVII e Art. $4^{\circ}$, IV, responsáveis pela exclusão da previsão de nascentes e olhos d'água intermitentes $^{132}$ como APP, em que o Min. Relator deu interpretação conforme a Constituição para configurar tais áreas como APP. ${ }^{133}$ Os demais artigos que diminuem a proteção de APP e RL foram declarados constitucionais.

\footnotetext{
${ }^{130}$ CHIAVARI, Joana; LOPES, Cristina Leme. Nota Técnica: Comentários ao voto do Ministro Luiz Fux, ADIs em face da Lei $N^{\circ}$ 12.651/2012 (Novo Código Florestal). Iniciativa para o Uso da Terra (Input) / Climate Policy Initiative, 2017. Disponível em <https://climatepolicyinitiative.org/wpcontent/uploads/2017/11/Nota_Tecnica_ADIs_Codigo_Florestal_Comentarios_ao_voto_do_Minis tro_Luis_Fux.pdf.> Acesso em 2 jun. 2018. p. 4.

${ }^{131}$ CHIAVARI, Joana; LOPES, Cristina Leme. Nota Técnica: Comentários ao voto do Ministro Luiz Fux, ADIs em face da Lei $N^{\circ}$ 12.651/2012 (Novo Código Florestal). Iniciativa para o Uso da Terra (Input) / Climate Policy Initiative, 2017. Disponível em <https://climatepolicyinitiative.org/wpcontent/uploads/2017/11/Nota_Tecnica_ADIs_Codigo_Florestal_Comentarios_ao_voto_do_Minis tro_Luis_Fux.pdf.> Acesso em 2 jun. 2018. p. 4.

132 A bióloga Nurit Bensusan explica a crucial importância dessas nascentes: "Essas nascentes, intermitentes ou temporárias, excluídas da proteção das APPs são até mais vulneráveis que as perenes e possuem um papel fundamental na preservação da disponibilidade de água. É sabido que em ambientes do semi-árido brasileiro, onde vivem 20 milhões de pessoas, a grande maioria das bacias hidrográficas é composta de nascentes e cursos d'água intermitentes. Nesse ambiente e em muitos outros, haverá uma significativa diminuição das áreas de preservação permanente". Conforme entrevista dada ao Instituto Socioambiental. Julgamento do Código Florestal no STF: os riscos para o Cerrado e o abastecimento de água. Disponível em< https://www.socioambiental.org/pt-br/noticias-socioambientais/julgamento-do-codigo-florestal-nostf-os-riscos-para-o-cerrado-e-o-abastecimento-de-agua> Acesso em 2 jun. 2018.

${ }^{133}$ CHIAVARI, Joana; LOPES, Cristina Leme. Nota Técnica: Comentários ao voto do Ministro Luiz Fux, ADIs em face da Lei $N^{\circ}$ 12.651/2012 (Novo Código Florestal). Iniciativa para o Uso da Terra (Input) / Climate Policy Initiative, 2017. Disponível em <https://climatepolicyinitiative.org/wpcontent/uploads/2017/11/Nota_Tecnica_ADIs_Codigo_Florestal_Comentarios_ao_voto_do_Minis tro_Luis_Fux.pdf.> Acesso em 2 jun. 2018. p. 4.
} 
O Art. 225, § $1^{\circ}$, III, da Constituição Federal prevê que somente a lei pode suprimir e alterar espaços territorialmente protegidos. Entretanto, como ressalta Vírginia Totti, os demais deveres do Poder Público em relação à garantia do direito fundamental ao meio ambiente ecologicamente equilibrado, previstos no mesmo artigo, "poderiam ser contrapostos para analisar a constitucionalidade de reduções tão bruscas de parâmetros legais de proteção"134, o que não aconteceu, privilegiando o controverso processo legislativo do novo Código Florestal. A vedação a "qualquer utilização que comprometa a integridade dos atributos" que justifiquem a proteção dos espaços territorialmente protegidos, contida no Art. 225 , $\S 1^{\circ}$, III, e o dever de "preservar e restaurar os processos ecológicos essenciais e prover o manejo ecológico das espécies e ecossistemas", contido no Art, $225 \S 1^{\circ}$, I, são exemplos de deveres que deveriam ter sido contrapostos à alarmante diminuição da proteção de APP e RL.

$\mathrm{O}$ terceiro ponto declarado inconstitucional pelo Min. Relator versa sobre as anistias construídas ao longo de diversos artigos, incluindo o tema 9 (Art. $7^{\circ}, \S 3^{\circ}$; Art. $17^{\circ}, \S 3^{\circ}$ ) e 19 (Art. 59, $\S 2^{\circ}, \S^{\circ}$ e $\S 5^{\circ}$; Art. 60). Fux atendeu ao pedido da PGR, declarando a inconstitucionalidade da expressão "realizada após 22 de julho de 2008", pois, nas palavras do Min. Relator:

Ao isentar os causadores de danos ambientais da obrigação de reparar o dano, sem que seja exigida demonstração de qualquer circunstância que signifique impedimento para o cumprimento deste dever, verifica-se patente a violação ao artigo 225, parágrafo $1^{\circ}, 3^{\circ}$ e $4^{\circ}$, e do artigo 186 da Constituição Federal. Não encontrei justificativa racional para o marco temporal apresentado pelo legislador. ${ }^{135}$

Ou seja, o Min. Relator reconheceu que tal previsão fere o princípio da função socioambiental da propriedade (Art. 186, CF/88), a obrigação constitucional do Poder Público de proteger o meio ambiente ${ }^{136}$ e a previsão

\footnotetext{
${ }^{134}$ GUIMARÃES, Virgínia Totti. A (in)constitucionalidade do Novo Código Florestal no STF e o voto de Luix $\quad$ Fux. Disponível em http://justificando.cartacapital.com.br/2017/12/05/inconstitucionalidade-do-novo-codigo-florestalno-stf-e-o-voto-de-luiz-fux/ Acesso em 2 jun. 2018.

${ }^{135}$ STF, ADIs n. 4901, 4902, 4903, 4937 e ADC n. 42, Rel. Ministro Luiz Fux, Brasília. Julgamento conjunto no Plenário do STF, concluído em 28 fev. 2018.

136 Art. 225, parágrafo $1^{\circ} \mathrm{e} 4^{\circ}$. Constituição da República Federativa do Brasil de 1988.
} 
de que "as condutas e atividades consideradas lesivas ao meio ambiente sujeitarão os infratores a sanções penais e administrativas, independentemente da obrigação de reparar os danos causados"137. Ainda no tocante à anistia, $\mathrm{O}$ Min. Relator também declarou a inconstitucionalidade dos artigos 59 e 60 (item 19), que versam sobre os Programas de Recuperação Ambiental (PRA), justificando seu voto principalmente sob o seguinte entendimento:

\begin{abstract}
A Constituição Federal prevê expressamente em seu artigo 225, parágrafo $3^{\circ}$, que "as condutas e atividades consideradas lesivas ao meio ambiente sujeitarão os infratores, pessoas físicas ou jurídicas, a sanções penais e administrativas, independentemente da obrigação de reparar os danos causados". Esse dispositivo indica e anila a intenção do constituinte ordinário de se utilizar do instrumental do direito sancionador para punir aquele que atente contra o meio ambiente. Por meio de Lei Ordinária, as previsões dos artigos 59 e 60, ao estabelecerem os PRA's, conferem verdadeira anistia condicional a estes infratores em total desconformidade com o mandamento constitucional. Ademais, a literalidade do artigo $225, \S 3^{\circ}$, da Constituição, impede a interpretação de que a obrigação de reparação de dano seja fungível em relação ao cumprimento de sanções penais e administrativas aplicáveis aos causadores de danos. Trata-se de obrigações cumulativas e não alternativas ou sucessivas por expressa dicção constitucional. Não poderia o legislador infraconstitucional, embora sobre o nobre pretexto de incentivar a recuperação desmatada irregularmente, promover programa de regularização que tornasse as duas condutas reparação e cumprimento de sanção como obrigações intercambiáveis. ${ }^{138}$ (Grifos meus)
\end{abstract}

O Min. Relator ainda vai além em sua fundamentação, e menciona os dados do PRODES que mostram um progressivo aumento do desmatamento após a aprovação do Código Florestal de 2012. Em seguida, reconheceu que "certamente, a anistia das infrações cometidas até julho de 2008 pode ser apontada como uma das possíveis causas para esse aumento"139. Como já foi exposto, o Código Florestal de 2012 claramente afronta o princípio da prevenção, que norteia as normas do Direito Ambiental brasileiro, o que o Min. Relator, no tocante à anistia de infrações administrativas e crimes ambientais pretéritos, reconheceu. Há também menção ao incentivo ao

\footnotetext{
${ }^{137}$ Art. 225, parágrafo $3^{\circ}$. Constituição da República Federativa do Brasil de 1988.

${ }^{138}$ STF, ADIs n. 4901, 4902, 4903, 4937 e ADC n. 42, Rel. Ministro Luiz Fux, Brasília. Julgamento conjunto no Plenário do STF concluído em 28 fev. 2018.

${ }^{139}$ STF, ADIs n. 4901, 4902, 4903, 4937 e ADC n. 42, Rel. Ministro Luiz Fux, Brasília. Julgamento conjunto no Plenário do STF concluído em 28 fev. 2018.
} 
desmatamento proporcionado por tal perdão, que gera a expectativa de constantes revisões à aplicação das normas sancionatórias:

Ao perdoar infrações administrativas e crimes ambientais pretéritos, o Código Florestal sinalizou uma despreocupação do Estado para com o Direito Ambiental, o que consequentemente mitigou os efeitos preventivos gerais específicos das normas de proteção do meio ambiente. A concessão da anistia por meio de simples reparação dos desmatamentos praticados até 2008 independentemente da aplicação de qualquer sanção, na minha concepção, incentiva a expectativa de que continuamente, de tempos em tempos, o Estado revisará a aplicação das normas sancionatórias para perdoar ilícitos eventualmente praticados pelos empreendedores. A contrário sensu, incentivase a ideia de que se pode desmatar livremente no período presente, sobre a expectativa de que no futuro novos programas de regularização ambiental sejam implementados com facilidades para a manutenção parcial de áreas já degradadas. ${ }^{140}$ (Grifos meus)

Para encerrar o voto relativo aos artigos 59 e 60, o Min. Relator entendeu que não pode haver substituição da multa pelo dever de reparação, pois o pressuposto de ser mais vantajoso "ao interesse público reparar o dano do que arrecadar financeiramente com multas", não se concretiza na realidade. No entendimento do Ministro, a sanção relativiza, "ainda que por vias financeiras, os danos consolidados anteriormente ao reflorestamento", visto que o reflorestamento posterior da área "consiste em medida paliativa de recuperação do bioma, mas não apaga os efeitos gerados pela ausência da vegetação nativa durante os anos anteriores" ${ }^{141}$.

Porém, curiosamente, o Min. Relator declarou a constitucionalidade das demais normas que constituem o regime diferenciado de recomposição que estão no capitulo XIII (disposições transitórias) do Código Florestal ${ }^{142}$.Como exemplo há o artigo 61-A, que autoriza a "continuidade das atividades agrossilvipastoris, de ecoturismo e de turismo rural em áreas rurais consolidadas até 22 de julho de 2008" nas APPs.

\footnotetext{
${ }^{140}$ STF, ADIs n. 4901, 4902, 4903, 4937 e ADC n. 42, Rel. Ministro Luiz Fux, Brasília. Julgamento conjunto no Plenário do STF concluído em 28 fev. 2018.

${ }^{141}$ STF, ADIs n. 4901, 4902, 4903, 4937 e ADC n. 42, Rel. Ministro Luiz Fux, Brasília. Julgamento conjunto no Plenário do STF concluído em 28 fev. 2018.

142 GUIMARÃES, Virgínia Totti. A (in)constitucionalidade do Novo Código Florestal no STF e o voto de Luix $\quad$ Fux. http://justificando.cartacapital.com.br/2017/12/05/inconstitucionalidade-do-novo-codigo-florestalno-stf-e-o-voto-de-luiz-fux/ Acesso em 2 jun. 2018.
} 
Em relação ao terceiro pilar do Código Florestal mencionado por Virginia Totti Guimaraes além da anistia e diminuição das regras de proteção ambiental, que consiste na "instituição de um mercado de pagamentos por serviços ambientais no Brasil”, houve declaração de constitucionalidade. O Min. Relator comparou o regime de cotas para proteção florestal ao mercado de crédito de carbono, e considerou a solução de mercado para a problemática ambiental uma alternativa eficaz às políticas de comando e controle $^{143}$. Como observa a autora, o Min. Relator deixou de analisar que tal regime de cotas beneficia exatamente quem não cumpria a legislação anterior, inclusive com o uso de recursos públicos, o que pode ser exemplificado com os Arts. 41, II, "d" e "e" e inciso III do Código Florestal $^{144}$.

$\mathrm{O}$ voto do relator trouxe mais uma mudança para a lei. A PGR, em relação ao $4^{\circ}$ tema, pedia a inconstitucionalidade do parágrafo único Art. $3^{\circ}$, que estende o tratamento diferenciado para "propriedades e posses rurais com até 4 módulos fiscais que desenvolvam atividades agrossilvipastoris"145 e "às terras indígenas demarcadas e às demais áreas tituladas de povos e comunidades tradicionais" $" 146$. O Min. Relator declarou a constitucionalidade do artigo, com exceção das palavras “dermacadas" e "tituladas". Ou seja, todas as terras indígenas e áreas de comunidades tradicionais terão direito ao tratamento diferenciado na recuperação de áreas desmatadas em desacordo com o Código de 1965, e não apenas as demarcadas e tituladas.

Os principais argumentos utilizados pelo Min. Relator para declarar o Código Florestal constitucional quase em sua integralidade serão

\footnotetext{
143 GUIMARÃES, Virgínia Totti. A (in)constitucionalidade do Novo Código Florestal no STF e o voto de Luix $\quad$ Fux. $\quad$ Disponível em http://justificando.cartacapital.com.br/2017/12/05/inconstitucionalidade-do-novo-codigo-florestalno-stf-e-o-voto-de-luiz-fux/ Acesso em 2 jun. 2018.

${ }^{144}$ GUIMARÃES, Virgínia Totti. A (in)constitucionalidade do Novo Código Florestal no STF e o $\begin{array}{lllll}\text { voto de } & \text { Luix } & \text { Fux. } & \text { Disponível }\end{array}$ http://justificando.cartacapital.com.br/2017/12/05/inconstitucionalidade-do-novo-codigo-florestalno-stf-e-o-voto-de-luiz-fux/ Acesso em 2 jun. 2018.

${ }^{145}$ Art. $3^{\circ}$, parágrafo único. Lei 12.651 de 25 de maio de 2012.

${ }^{146}$ Redação do Art. $3^{\circ}$, parágrafo único, Lei 12.651/2012 antes do julgamento da ADI 4903.
} 
apresentados na discussão do resultado do julgamento. Tais entendimentos do Min. Relator prevaleceram, e deram o tom do resultado final.

\subsection{Resultado do julgamento}

Após o voto do Min. Relator, pedido de vista da presidente do STF, Ministra Carmen Lúcia, suspendeu o julgamento, que foi retomado apenas em 21.02.2018, e terminado em 28.02.2018. Como a íntegra da maioria dos votos ainda não foi publicada, não foi possível analisar neste trabalho se as recomendações dos documentos científicos contrários ao vigente Código Florestal foram analisadas para cada mudança trazida pela lei ${ }^{147}$. Porém, é possível evidenciar quais argumentos jurídicos prevaleceram, e como os princípios do Direito Ambiental foram afetados. A tabela abaixo resume o resultado final do julgamento conjunto das ADIs 4901, 4902, 4903 e 4937 e ADC 42, que declarou constitucional o Código Florestal quase em sua totalidade.

\begin{tabular}{|c|c|c|c|}
\hline \multicolumn{4}{|c|}{ Julgamento das ações sobre o Código Florestal de 2012 no STF } \\
\hline & $\begin{array}{lc}\text { Tema } \quad \text { Discutido } & \text { e } \\
\text { Consequências Práticas } & \\
\end{array}$ & Artigos & Resultado do julgamento \\
\hline 1 & $\begin{array}{l}\text { Tema: Extensão dos conceitos } \\
\text { de "interesse social" " "utilidade } \\
\text { pública" e desconsideração de } \\
\text { "alternativa técnica e } \\
\text { locacional" e "prévia } \\
\text { autorização" com o objetivo de } \\
\text { ampliar as possibilidades de } \\
\text { desmatamento em Áreas de } \\
\text { Preservação Permanente (APPs) } \\
\text { Consequências: Aumenta o } \\
\text { desmatamento. Redução da } \\
\text { proteção de APPs. Prejuízo nas } \\
\text { suas funções. }\end{array}$ & $\begin{array}{l}\text { Art. 3, } \\
\text { incisos } \\
\text { VIII; } \\
\text { VIII, b, } \\
\text { e IX; }\end{array}$ & $\begin{array}{l}\text { Concede interpretação conforme a } \\
\text { Constituição para o Art. } 3^{\circ} \text {, VIII e IX. } \\
\text { As intervenções por interesse social ou } \\
\text { utilidade pública têm de ser } \\
\text { excepcionais, quando não houver } \\
\text { "alternativa técnica e/ou locacional" à } \\
\text { atividade proposta. Declara, no Art. } 3^{\text {, }} \text {, } \\
\text { VIII, b, inconstitucionais instalações } \\
\text { para "gestão de resíduos" e } \\
\text { "instalações necessárias à realização } \\
\text { de competições esportivas estaduais, } \\
\text { nacionais ou internacionais" } \\
\text { nas APPs }\end{array}$ \\
\hline & $\begin{array}{l}\text { Tema: Nascentes e olhos de } \\
\text { água intermitentes deixam de } \\
\text { ser protegidas por APPs. }\end{array}$ & $\begin{array}{l}\text { Art. } 3^{\circ}, \\
\text { XVII; Art. } \\
4^{\circ}, \text { IV }\end{array}$ & $\begin{array}{l}\text { Interpretação conforme a } \\
\text { Constituição ao Art. } 3^{\circ}, \text { XVII, "para } \\
\text { fixar a interpretação de que os entornos }\end{array}$ \\
\hline
\end{tabular}

${ }^{147}$ O Ministro Dias Toffoli chegou a mencionar que houve dificuldades no julgamento de tantos artigos, com questões técnicas e muitas manifestações da sociedade, pelo método de votos individuais para cada dispositivo. 


\begin{tabular}{|c|c|c|c|}
\hline 2 & $\begin{array}{l}\text { Consequências: Permite o } \\
\text { desmatamento das matas à beira } \\
\text { de nascentes e poços } \\
\text { intermitentes ou temporários. } \\
\text { Pode comprometer o } \\
\text { abastecimento de água e ter } \\
\text { influência sobre o clima local. }\end{array}$ & & $\begin{array}{l}\text { das nascentes e dos olhos d'água } \\
\text { intermitentes configuram área de } \\
\text { preservação permanente". } \\
\text { Interpretação conforme a } \\
\text { Constituição ao Art. } \mathbf{4}^{\circ} \text {, IV, "para fixar } \\
\text { a interpretação de que os entornos das } \\
\text { nascentes e dos olhos d'água } \\
\text { intermitentes configuram área de } \\
\text { preservação ambiental" }\end{array}$ \\
\hline 3 & $\begin{array}{l}\text { Tema: Medição das APPs de } \\
\text { beira de rio pelo "leito regular", } \\
\text { e não mais pelo leito na época da } \\
\text { cheia } \\
\text { Consequências: Isso pode } \\
\text { comprometer a estabilidade e } \\
\text { qualidade do solo, o } \\
\text { abastecimento de água, a vida de } \\
\text { rios, nascentes e animais, além } \\
\text { de provocar enxurradas, } \\
\text { inundações e deslizamento. }\end{array}$ & $\begin{array}{l}\text { Art. } 3^{\circ} \text {, } \\
\text { XIX }\end{array}$ & Constitucional \\
\hline 4 & $\begin{array}{l}\text { Tema: Tratamento diferenciado } \\
\text { na recuperação de áreas } \\
\text { desmatadas ilegalmente para } \\
\text { pequenas posses e propriedades } \\
\text { (até quatro módulos fiscais), } \\
\text { Terras Indígenas (TIs) } \\
\text { demarcadas e áreas tituladas de } \\
\text { povos e comunidades } \\
\text { tradicionais } \\
\text { Consequências: Libera os } \\
\text { produtores rurais da obrigação } \\
\text { de recuperar áreas desmatadas } \\
\text { ilegalmente, o que afeta até a } \\
\text { produtividade agrícola. }\end{array}$ & $\begin{array}{l}\text { Artigo 3, } \\
\text { parágrafo } \\
\text { único }\end{array}$ & 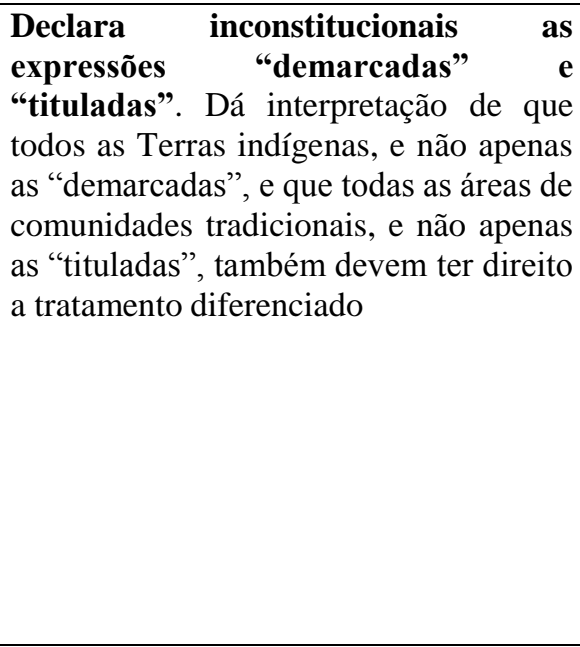 \\
\hline 5 & $\begin{array}{l}\text { Tema: Ausência de padrão } \\
\text { mínimo para APP de } \\
\text { reservatórios; Dispensa de } \\
\text { APP no entorno de } \\
\text { reservatórios artificiais e em } \\
\text { reservatórios naturais ou } \\
\text { artificiais de água com } \\
\text { superfície inferior a um } \\
\text { hectare } \\
\text { Consequências: Permite } \\
\text { desmatar as matas na beira } \\
\text { dos reservatórios com } \\
\text { autorização do SISNAMA e } \\
\text { não recuperar aquelas já } \\
\text { desmatadas. A consequência } \\
\text { direta é a redução da vida útil } \\
\text { desses corpos de água. }\end{array}$ & $\begin{array}{l}\text { Art. } 4^{\circ} \text {, } \\
\text { III; } \S 1^{\circ} \text { e } \\
\S 4^{\circ}\end{array}$ & Constitucional \\
\hline
\end{tabular}




\begin{tabular}{|c|c|c|c|}
\hline 6 & $\begin{array}{l}\text { Tema: Permissão de plantio em } \\
\text { várzea para pequena } \\
\text { propriedade ou posse rural (até } \\
\text { quatro módulos fiscais) } \\
\text { Consequências: Permite o } \\
\text { desmatamento na beira de rios. } \\
\text { Isso pode comprometer a } \\
\text { estabilidade e qualidade do solo, } \\
\text { o abastecimento de água, a vida } \\
\text { de rios, nascentes e animais. }\end{array}$ & $\begin{array}{l}\text { Art. } 4^{\circ}, \S \\
5^{\circ}\end{array}$ & Constitucional \\
\hline 7 & $\begin{array}{l}\text { Tema: Permite a aquicultura } \\
\text { (criação de peixes, crustáceos e } \\
\text { moluscos) em APP nos imóveis } \\
\text { rurais médios (de até } 15 \\
\text { módulos fiscais) } \\
\text { Consequências: Permite o } \\
\text { desmatamento na beira de rios, } \\
\text { obras e instalações que podem } \\
\text { alterar os ecossistemas. Ouso de } \\
\text { substâncias químicas na } \\
\text { produção de peixes e crustáceos } \\
\text { também pode contaminar esses } \\
\text { ecossistemas. }\end{array}$ & $\begin{array}{l}\text { Art. } 4^{\circ}, \S \\
6^{\circ}\end{array}$ & Constitucional \\
\hline 8 & $\begin{array}{l}\text { Tema: Redução largura mínima } \\
\text { de APP de reservatório artificial } \\
\text { destinado a geração de energia } \\
\text { ou de abastecimento público } \\
\text { Consequências: Permite } \\
\text { desmatar as matas na beira dos } \\
\text { reservatórios e não recuperar } \\
\text { aquelas já desmatadas. A } \\
\text { consequência direta é a redução } \\
\text { da vida útil desses corpos de } \\
\text { água. }\end{array}$ & $\begin{array}{l}\text { Art. } \quad 5^{\circ} \mathrm{e} \\
62\end{array}$ & Constitucional \\
\hline 9 & $\begin{array}{l}\text { Tema: Controle diferenciado, } \\
\text { mais rigoroso, do desmatamento } \\
\text { e atividades agropecuárias em } \\
\text { propriedades onde ocorreu } \\
\text { desmatamento irregular após } 22 \\
\text { de julho de } 2008 \text {. } \\
\text { Consequências: Beneficia } \\
\text { quem desmatou ilegalmente, } \\
\text { estimulando a impunidade. Ao } \\
\text { mesmo tempo, é injusto com os } \\
\text { produtores rurais que } \\
\text { cumpriram a norma antiga. } \\
\begin{array}{l}\text { Consolida o } \\
\text { diferenciado. }\end{array}\end{array}$ & $\begin{array}{l}\text { Art. } \quad 7^{\circ}, \\
\S 3^{\circ} ; \quad \text { Art. } \\
17^{\circ}, \S 3^{\circ}\end{array}$ & Constitucional \\
\hline & $\begin{array}{lcr}\text { Tema: } & \text { Permissão } & \text { de } \\
\text { implantação } & \text { de } & \text { projetos }\end{array}$ & $\begin{array}{l}\text { Art. } \quad 8^{\circ}, \\
\S 2^{\circ}\end{array}$ & Constitucional \\
\hline
\end{tabular}




\begin{tabular}{|c|c|c|c|}
\hline 10 & $\begin{array}{l}\text { habitacionais em mangues e } \\
\text { restingas } \\
\text { Consequências: Permite } \\
\text { desmatar alguns dos } \\
\text { ecossistemas mais frágeis, } \\
\text { ameaçados e importantes do } \\
\text { país. Mangues e restingas são } \\
\text { berçários e habitat de muitas } \\
\text { espécies marinhas e terrestres. A } \\
\text { degradação desses ambientes } \\
\text { pode causar ainda erosão } \\
\text { costeira e o assoreamento de } \\
\text { canais navegáveis, bacias e } \\
\text { lagoas }\end{array}$ & & \\
\hline 11 & $\begin{array}{l}\text { Tema: Manejo florestal e o } \\
\text { exercício de atividades } \\
\text { agrossilvipastoris em áreas com } \\
\text { inclinação entre } 25^{\circ} \text { e } 45 \\
\text { Consequências: Permite } \\
\text { desmatar encostas e morros, o } \\
\text { que pode provocar mortes e } \\
\text { destruição por enxurradas, } \\
\text { inundações e deslizamentos }\end{array}$ & Art. 11 & Constitucional \\
\hline 12 & $\begin{array}{l}\text { Tema: Possibilidade de redução } \\
\text { da Reserva Legal (RL) de } 80 \% \text { a } \\
50 \% \text { pela existência de TIs e } \\
\text { Unidades de Conservação } \\
\text { (UCs) no município ou quando } \\
\text { o Estado tiver Zoneamento } \\
\text { Ecológico Econômico (ZEE) e } \\
\text { mais de } 65 \% \text { de UC em seu } \\
\text { território } \\
\text { Consequências: Reduz a } \\
\text { proteção e permite desmatar } \\
\text { grandes áreas de vegetação } \\
\text { nativa, com consequências } \\
\text { negativas sobre animais, } \\
\text { processos ecológicos e o clima }\end{array}$ & $\begin{array}{l}\text { Art. } 12, \\
\S 4^{\circ} \text { e } \$ 5^{\circ}\end{array}$ & Constitucional \\
\hline 13 & $\begin{array}{l}\text { Tema: Dispensa de RL para: } \\
\text { empreendimentos } \\
\text { abastecimento público de água e } \\
\text { tratamento de esgoto; } \\
\text { hidrelétricas; rodovias e } \\
\text { ferrovias } \\
\text { Consequências: Permite } \\
\text { desmatar grandes áreas de } \\
\text { vegetação nativa, com } \\
\text { consequências negativas sobre } \\
\text { animais, processos ecológicos e } \\
\text { o clima }\end{array}$ & $\begin{array}{l}\text { Art. } 12 \text { } 12 \\
6^{-}, \quad \S 7^{\circ} \text { e } \\
\S 8^{\circ}\end{array}$ & Constitucional \\
\hline 14 & $\begin{array}{l}\text { Tema: Dispensa } \\
\text { recomposição de } \mathrm{RL} \text { se }\end{array}$ & Art. 68 & Constitucional \\
\hline
\end{tabular}




\begin{tabular}{|c|c|c|c|}
\hline & $\begin{array}{l}\text { desmatamento foi feito de } \\
\text { acordo com lei em vigor à época } \\
\text { Consequências: Libera da } \\
\text { obrigação de recuperar vastas } \\
\text { áreas de vegetação nativa. }\end{array}$ & & \\
\hline 15 & $\begin{array}{l}\text { Tema: Possibilidade de } \\
\text { instituição de servidão } \\
\text { ambiental e Cotas de Reserva } \\
\text { Ambiental (CRA) sobre área } \\
\text { excedente quando houver } \\
\text { redução de RL, para fins de } \\
\text { regularização, previsto em ZEE } \\
\text { Consequências: Permite não } \\
\text { recuperar áreas já desmatadas } \\
\text { ilegalmente. }\end{array}$ & $\begin{array}{l}\text { Art. 13, } \\
\S 1^{\circ}\end{array}$ & Constitucional \\
\hline 16 & $\begin{array}{l}\text { Tema: Permissão do cômputo } \\
\text { de APP no percentual de RL } \\
\text { Consequências: } \\
\text { Descaracterização das áreas de } \\
\text { RL }\end{array}$ & Art. 15 & Constitucional \\
\hline 17 & $\begin{array}{l}\text { Tema: Permissão de } \\
\text { desmatamento em imóvel com } \\
\text { área subutilizada e área utilizada } \\
\text { de forma inadequada }\end{array}$ & Art. 28 & Constitucional \\
\hline 18 & $\begin{array}{l}\text { Tema: Compensação de RL no } \\
\text { mesmo bioma por meio de Cota } \\
\text { de Reserva Ambiental (Art. } 48 \text {, } \\
\S 2^{\circ} \text { ) } \\
\text { Consequências: Permite a um } \\
\text { produtor rural compensar área } \\
\text { desmatada em sua propriedade, } \\
\text { mas a muitos quilometros de } \\
\text { distância, inclusive em outros } \\
\text { Estados. Isso não reduz o dano } \\
\text { ambiental provocado no local do } \\
\text { desmatamento. }\end{array}$ & $\begin{array}{l}\text { Art. } \\
48, \\
\S 2^{\circ} \\
\text { Art. } \\
66, \\
\S 5^{\circ} \\
\text { II, III } \\
\text { e IV; } \\
\S 6^{\circ}\end{array}$ & $\begin{array}{l}\text { Interpretação conforme } \\
\text { Constituição ao Art. } \mathbf{4 8}, \S \mathbf{2}^{\mathbf{0}} \text { "para } \\
\text { permitir compensação apenas entre áreas } \\
\text { com identidade ecológica". } \\
\text { Constitucional - Art. } \mathbf{6 6 ,} \mathbf{5 5}^{\mathbf{0}} \text { e } \S \mathbf{6}^{\circ} \text {, } \\
\text { declarando constitucional o critério do } \\
\text { bioma para esses dispositivos, o que não } \\
\text { deve valer para RL, e sim para as demais } \\
\text { formas de compensação. }\end{array}$ \\
\hline 19 & 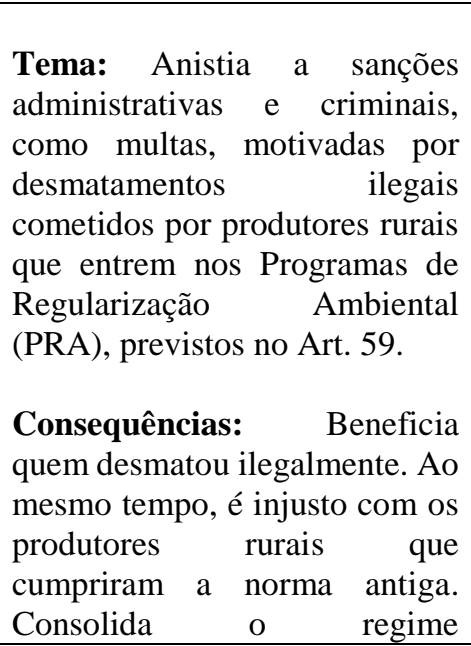 & $\begin{array}{l}\text { Art. } 59 \\
\$ 4^{\circ} \text { e } \$ 5^{\circ} \\
\text { Art. } 60\end{array}$ & $\begin{array}{l}\text { Interpretação conforme } \\
\text { Constituição ao Art. } 59, \mathbf{\$ 4}^{\mathbf{0}} \text { e } \$ 5^{\circ} \text {, “de } \\
\text { modo a afastar, no decurso da execução } \\
\text { dos termos de compromissos subscritos } \\
\text { nos programas de regularização } \\
\text { ambiental, o risco de decadência ou } \\
\text { prescrição, seja dos ilícitos ambientais } \\
\text { praticados antes de } 22.7 .2008 \text {, seja das } \\
\text { sançães deles decorrentes, aplicando-se } \\
\text { extensivamente o disposto no } \S 1^{\circ} \text { do } \\
\text { Art. } 60 \text { da Lei } 12.651 / 2012, \text { segundo o } \\
\text { qual "a prescrição ficará interrompida } \\
\text { durante o período de suspensão da } \\
\text { pretensão punitiva"”, } \\
\text { Constitucional - Art. } \mathbf{6 0}\end{array}$ \\
\hline
\end{tabular}




\begin{tabular}{|c|c|c|c|}
\hline & $\begin{array}{l}\text { diferenciado. Pode incentivar } \\
\text { mais mudanças na lei contra o } \\
\text { meio ambiente }\end{array}$ & & \\
\hline 20 & $\begin{array}{l}\text { Tema: Permissão de plantio de } \\
\text { exóticas para recomposição de } \\
\text { RL } \\
\text { Consequências: Beneficia } \\
\text { quem desmatou ilegalmente, ao } \\
\text { abrir caminho a atividades } \\
\text { econômicas lucrativas na área } \\
\text { desmatada (silvicultura ou } \\
\text { fruticultura), e impede a } \\
\text { recomposição de todos os } \\
\text { serviços ambientais prestados } \\
\text { pela floresta. }\end{array}$ & $\begin{array}{l}\text { Art. } \quad 66, \\
\$ 3^{\circ}\end{array}$ & Constitucional \\
\hline 21 & $\begin{array}{l}\text { Tema: Dispensas de } \\
\text { recuperação das áreas } \\
\text { desmatadas até } 22 \text { de julho de } \\
2008 \text { de acordo com o tamanho } \\
\text { do imóvel. } \\
\text { Consequências: Beneficia } \\
\text { quem desmatou ilegalmente, } \\
\text { estimulando a impunidade. Ao } \\
\text { mesmo tempo, é injusto com os } \\
\text { produtores rurais que } \\
\text { cumpriram a norma antiga, } \\
\text { obrigando-os hoje a proteger a } \\
\text { vegetação segundo padrões } \\
\text { mais rigorosos. Pode incentivar } \\
\text { mais mudanças na lei contra o } \\
\text { meio ambiente }\end{array}$ & $\begin{array}{l}\text { Art. 61-A } \\
\text { e } 61-B, \\
61-C, 63 \\
\text { e } 67\end{array}$ & Constitucional \\
\hline 22 & $\begin{array}{l}\text { Tema: Permite a concessão de } \\
\text { crédito agrícola por instituições } \\
\text { financeiras apenas com base no } \\
\text { CAR }\end{array}$ & Art. 78-A & Constitucional \\
\hline
\end{tabular}

${ }^{148}$ Fonte: adaptação de tabela que continha originalmente o voto do Min. Relator Luiz Fux para os 22 temas discutidos, atualizada com o resultado final do julgamento e algumas alterações e adaptações no texto (a partir da redação dos artigos da Lei 12.651/2012). A tabela com os votos do Min. Relator Luiz $\quad$ Fuz está disponível em https://www.socioambiental.org/sites/blog.socioambiental.org/files/nsa/arquivos/tabela_voto_luiz fux - codigo florestal.pdf ; o resultado final do julgamento está disponível, para cada ADI, em: http://www.stf.jus.br/portal/peticaoInicial/verPeticaoInicial.asp?base=ADIN\&s1=4901\&processo= 4901;

http://www.stf.jus.br/portal/peticaoInicial/verPeticaoInicial.asp?base=ADIN\&s $1=4902 \&$ processo= 4902;

http://www.stf.jus.br/portal/peticaoInicial/verPeticaoInicial.asp?base=ADIN\&s $1=4903 \&$ processo= 4903; http://www.stf.jus.br/portal/peticaoInicial/verPeticaoInicial.asp?base=ADIN\&s1=4937\&processo= 4937 Acesso em 2 jun. 2018. 
Apesar da importante declaração de inconstitucionalidade e interpretação conforme de alguns artigos, o resultado foi alarmantemente desfavorável para o meio ambiente.

O Ministro Ricardo Lewandowski foi o que mais defendeu tal direito: inicialmente, fez um belo discurso em defesa do biocentrismo e do in dubio pro natura em casos de dúvida, "homenageando-se os princípios da precaução e do cuidado"149; em seguida, acompanhou os votos do Min. Relator, Cármen Lúcia e Marco Aurélio, optando sempre pela visão mais favorável ao meio ambiente quando houvesse conflito entre eles ${ }^{150}$. Houve também o extremo oposto, a exemplo do Ministro Gilmar Mendes, que considerou o Código Florestal totalmente constitucional.

Em muitos artigos que diminuem o nível de proteção das APPs e RL houve votos pela inconstitucionalidade, mas não alcançaram maioria ${ }^{151}$. Como exemplo há a previsão da medição de APPs pelo leito regular do curso d'água, declarada inconstitucional apenas por Carmen Lúcia e Ricardo Lewandowski; e a autorização do computo de APP no cálculo de RL, declarada inconstitucional por Marco Aurélio, Edson Fachin, Rosa Weber e Ricardo Lewandowski.

As posições mais favoráveis ao meio ambiente não prevaleceram para a maioria dos pontos discutidos, incluindo a anistia da responsabilidade ambiental. No final, o Direito Ambiental e os diversos cientistas e ambientalistas que participaram das discussões sobre a Lei 12.651 foram derrotados. Os interesses da bancada ruralistas venceram, num dos

\footnotetext{
${ }^{149}$ STF, ADIs n. 4901, 4902, 4903, 4937 e ADC n. 42, Rel. Ministro Luiz Fux, Brasília. Julgamento conjunto no Plenário do STF concluído em 28 fev. 2018.

${ }^{150} \mathrm{O}$ Ministro Ricardo Lewandowski iniciou sua fala defendendo a visão biocêntrica do direito ao meio ambiente, em contraposição ao antropocentrismo que prevalece no ordenamento jurídico brasileiro. O Ministro também mencionou: a Carta da Terra; a Encíclica Louvado Sejas, de autoria do Papa Francisco; o MS n. 22164-0-SP, Rel. Ministro Celso de Mello, citado no primeiro capítulo deste trabalho; e a Constituição de 2008 do Equador, em que o meio ambiente e a natureza figuram como sujeitos de direitos.

${ }^{151}$ A organização Terra de Direitos criou uma tabela que facilita a visualização de como votou cada Ministro do STF nos temas discutido: BITTENCOURT, Naiara Andreoli. Placar do julgamento do Código Florestal no STF - Lei 12.651/2012 (ADIS 4901, 4902, 4903, 4937 e ADC 42). Disponível em http://terradedireitos.org.br/uploads/arquivos/Quadro-ADIs-Codigo-Florestal-final.pdf Acesso em 2 jun. 2018.
} 
julgamentos mais importantes para o Direito Ambiental brasileiro, em detrimento inclusive do documento elaborado pelo SBPC anexado às ADIs.

Os princípios norteadores do Direito Ambiental, desse modo, não prevaleceram no Supremo Tribunal Federal nas ações que discutiam uma lei notoriamente contrária à função socioambiental da propriedade, prevenção, precaução, vedação ao retrocesso e os deveres do Poder Público para garantir um meio ambiente sadio para presentes e futuras gerações. $O$ dever de sancionar nas três esferas aqueles que praticarem conduta e atividade lesiva ao meio ambiente foi mitigado. De modo geral, pode-se dizer que as previsões do Art. 225 da Constituição Federal e os princípios do Direito Ambiental foram mitigados e relativizados em face dos interesses da cada vez mais poderosa bancada ruralista do Congresso Nacional.

O Min. Relator iniciou sua fala classificando o tema como "extremamente técnico", que em primeiro momento iria além da "capacidade institucional" e "expertise" do STF. Diante das manifestações reconheceu que alguns aspectos geraram "colisões de normas genéricas", e passam por princípios que "conciliem desenvolvimento sustentável com o meio ambiente" ${ }^{152}$. Tal fala já demonstra uma visão ultrapassada, visto que os dois podem, e devem caminhar juntos.

A ideia de "conciliação", mencionada mais de uma vez por Luiz Fux, leva à ideia de um falso conflito entre a preservação de um meio ambiente ecologicamente equilibrado, de um lado, e a livre iniciativa, erradicação da pobreza, redução das desigualdades sociais, proteção da propriedade, mercado de trabalho, atendimento às necessidades básicas de consumo e o desenvolvimento social e nacional, do outro ${ }^{153}$. As questões ambientais não devem ser debatidas sob a ótica de um "duelo valorativo entre a tutela ambiental e a tutela do desenvolvimento, tendo como centro de gravidade o bem comum", mencionado pelo Ministro. Não há um duelo, visto que esses

\footnotetext{
${ }^{152}$ STF, ADIs n. 4901, 4902, 4903, 4937 e ADC n. 42, Rel. Ministro Luiz Fux, Brasília. Julgamento conjunto no Plenário do STF concluído em 28 fev. 2018.

${ }^{153}$ Todos esses direitos previstos na Constituição Federal de 1988 foram mencionados por Luix Fux como partes de tal "conciliação" com o meio ambiente ecologicamente equilibrado.
} 
dois fatores devem estar diretamente interligados, e não postos em polos opostos, conectados por um centro apaziguador. O meio ambiente ecologicamente equilibrado é condição para uma produção agrícola mais eficiente, desenvolvimento econômico e a própria vida e bem comum, como menciona Virgínia Totti Guimaraes:

As questões ambientais precisam ser reposicionadas de modo que elas sejam lidas como condições para a manutenção da vida, com qualidade e dignidade, do modo de viver de povos tradicionais e indígenas, da prática da agricultura familiar e até mesmo do desenvolvimento econômico, e não como algo que se contrapõe ao direito à livre iniciativa. ${ }^{154}$

O Min. Relator defendeu oralmente, no Plenário do STF, que o "princípio da vedação ao retrocesso não se sobrepõe ao princípio democrático, no afã de transferir ao Judiciário funções inerentes aos Poderes Executivo e Legislativo" ${ }^{155}$. Em seguida, usou como argumento para a autocontenção do Judiciário diante das ações sobre o Código Florestal a capacidade e legitimidade institucional e democrática do Legislativo. O Min. Relator defendeu essa ideia com base na "Discricionariedade epistêmica e hermenêutica garantida ao Legislativo pela Constituição" e "a transparência e extensão do Processo Legislativo desenvolvido, o que confere legitimidade adicional ao produto da atividade do Congresso Nacional" ${ }^{156}$.

Esse entendimento prevaleceu no julgamento, dando o tom do resultado final. O Ministro Barroso chegou a dizer, no Plenário do STF, que a terceira parte de seu voto é, parcialmente, “uma profissão de fé na liberdade de conformação do legislador, na medida em que não seja manifestamente irrazoável ou desproporcional a sua atuação" ${ }^{157}$.

Como já foi mencionado, tal processo legislativo foi cercado de controvérsias, e feito por políticos que não representam a diversidade da

\footnotetext{
${ }^{154}$ GUIMARÃES, Virgínia Totti. A (in)constitucionalidade do Novo Código Florestal no STF e o voto de Luix $\quad$ Fux. $\quad$ Disponível em http://justificando.cartacapital.com.br/2017/12/05/inconstitucionalidade-do-novo-codigo-florestalno-stf-e-o-voto-de-luiz-fux/ Acesso em 2 jun. 2018.

${ }^{155}$ STF, ADIs n. 4901, 4902, 4903, 4937 e ADC n. 42, Rel. Ministro Luiz Fux, Brasília. Julgamento conjunto no Plenário do STF concluído em 28 fev. 2018.

${ }^{156}$ STF, ADIs n. 4901, 4902, 4903, 4937 e ADC n. 42, Rel. Ministro Luiz Fux, Brasília. Julgamento conjunto no Plenário do STF concluído em 28 fev. 2018.

${ }^{157}$ STF, ADIs n. 4901, 4902, 4903, 4937 e ADC n. 42, Rel. Ministro Luiz Fux, Brasília. Julgamento conjunto no Plenário do STF concluído em 28 fev. 2018.
} 
sociedade brasileira. Entretanto, tal processo legislativo acabou prevalecendo sobre os princípios do Direito Ambiental, os deveres do Poder Público para garantir o direito ao meio ambiente ecologicamente equilibrado e os diversos alertas da comunidade científica contrários à Lei 12.651/2012.

O enfraquecimento do princípio da vedação ao retrocesso ambiental diante das escolhas do Poder Legislativo foi o principal argumento utilizado para declarar a constitucionalidade da maior parte do Código Florestal de 2012, que não teria violado o núcleo essencial do direito ao meio ambiente ecologicamente equilibrado. Contudo, outros argumentos a favor da constitucionalidade também foram usados no Plenário do STF: a suposta falta de dados empíricos; inaplicabilidade do Código Florestal de 1965, supostamente muito distante da realidade; inconstitucionalidade fundada em supostos "achismos"; insegurança jurídica trazida pela declaração de inconstitucionalidade dos PRAs e áreas rurais consolidadas; inexistência de anistia, que seria apenas um incentivo à recuperação das áreas degradadas, sem prejuízo das sanções ${ }^{158}$.

No dia 28.02.2018, o voto do Ministro Celso de Mello desempatou três pontos centrais ainda em debate ${ }^{159}$, no único voto disponibilizado na íntegra em escrito até esse momento: a possibilidade de compensação ambiental no mesmo bioma, e não mais na mesma microbacia; a autorização para o Poder Público reduzir o território de reserva legal em cidades que tenham mais de $50 \%$ da área demarcada como terra indígena; e a própria anistia, ponto que gerou intensos debates ${ }^{160}$. Celso de Mello votou pela constitucionalidade desses três pontos, em um voto curioso.

O Ministro, inicialmente, fez uma longa exposição e defesa dos seguintes temas abordados neste trabalho: direito fundamental ao meio

\footnotetext{
${ }^{158}$ STF, ADIs n. 4901, 4902, 4903, 4937 e ADC n. 42, Rel. Ministro Luiz Fux, Brasília. Julgamento conjunto no Plenário do STF concluído em 28 fev. 2018.

159 TEIXEIRA, Matheus; CARNEIRO, Luiz Orlando. STF valida quase todo Código Florestal e desagrada ambientalistas. Disponível em https://www.jota.info/stf/stf-valida-quase-todo-codigoflorestal-e-desagrada-ambientalistas-28022018 Acesso em 2 jun. 2018.

${ }_{160}$ TEIXEIRA, Matheus; CARNEIRO, Luiz Orlando. STF valida quase todo Código Florestal e desagrada ambientalistas. Disponível em https://www.jota.info/stf/stf-valida-quase-todo-codigoflorestal-e-desagrada-ambientalistas-28022018 Acesso em 2 jun. 2018.
} 
ambiente ecologicamente equilibrado e os deveres do Poder Público para garanti-lo; respeitando ao princípio da proporcionalidade; princípio da prevenção e precaução; e o princípio da vedação ao retrocesso, mencionando inclusive o julgamento do REsp 302.906/SP, que teve como Relator o Ministro Herman Benjamin. Para tal, citou doutrina, jurisprudência e até os princípios da Declaração de Estocolmo e Rio 92. Em uma bonita defesa da eficácia que deve ser dada às previsões constitucionais, não se podendo tolerar que o Poder Público atue de forma insuficiente, o Ministro entendeu que:

É preciso proclamar que as Constituições consubstanciam ordens normativas cuja eficácia, autoridade e valor não podem ser afetados ou inibidos pela voluntária inação ou por ação insuficiente das instituições estatais. Não se pode tolerar que os órgãos do Poder Público, descumprindo, por inércia e omissão, o dever de emanação normativa que lhes foi imposto, infrinjam, com esse comportamento negativo, a própria autoridade da Constituição e afetem, em consequência, o conteúdo eficacial dos preceitos que compõem a estrutura normativa da Lei Maior. ${ }^{161}$

Entendeu também que o STF não estaria transgredindo a separação de poderes, e sim desempenhando "o papel a ela outorgado pela própria Constituição da República, com o objetivo de impedir que a atuação normativa insuficiente do Poder Público" degrade a "autoridade e a supremacia da Lei Fundamental"162. O alcance do princípio da vedação ao retrocesso foi discutido no final do voto, havendo menção ao entendimento da Ministra Carmen Lúcia, que também votou pela constitucionalidade da anistia $^{163}$ :
A aplicação do princípio da proibição de retrocesso socioambiental não pode engessar a ação legislativa e administrativa, sendo forçoso admitir certa margem de discricionariedade às autoridades públicas em matéria ambiental. Todavia, as medidas que restringem direitos sociais ou ecológicos devem ser submetidas a um rigoroso controle de constitucionalidade que avalie sua proporcionalidade e sua razoabilidade, bem como seu respeito ao núcleo essencial dos direitos socioambientais, sob pena de irreversibilidade dos prejuízos às presentes e futuras gerações. Não é compatível com a Constituição

\footnotetext{
${ }^{161}$ STF, ADIs n. 4901, 4902, 4903, 4937 e ADC n. 42, Rel. Ministro Luiz Fux, Brasília. Julgamento conjunto no Plenário do STF concluído em 28 fev. 2018.

${ }^{162}$ STF, ADIs n. 4901, 4902, 4903, 4937 e ADC n. 42, Rel. Ministro Luiz Fux, Brasília. Julgamento conjunto no Plenário do STF concluído em 28 fev. 2018.

163 Naiara Andreoli Bittencourt, Placar do julgamento do Código Florestal no STF - Lei 12.651/2012. Disponível em http://terradedireitos.org.br/noticias/noticias/placar-do-julgamento-docodigo-florestal-no-stf-lei-126512012/22752
} 
da República, portanto, a flexibilização da legislação ambiental, sem que sejam simultaneamente editadas medidas que compensem o impacto ambiental causado por normas mais permissivas. ${ }^{164}$ (Grifos meus)

O Ministro Celso de Mello seguiu tal argumento, entendendo, mesmo após a ampla dissertação sobre os princípios do Direito Ambiental e sua importância, que o núcleo essencial do direito ao meio ambiente ecologicamente equilibrado não foi comprometido pela área rural consolidada, anistia e a diminuição da proteção de APP e RL. Desse modo, acompanhou quase integralmente o voto do Relator Luiz Fux, entendendo que deveriam ser privilegiadas as decisões do Poder Legislativo, com fundamentação no princípio democrático.

O Ministro Celso de Mello, diferentemente do Relator, posicionou-se pela constitucionalidade da anistia, argumentando que ela "constitui uma das expressões da clemência soberana do Estado" e tem efeitos "radicais, incidindo, retroativamente, sobre o próprio fato delituoso", além de ser "apta a desconstituir a própria autoridade da coisa julgada”.

Parece no mínimo contraditório, no voto de desempate de uma questão tão alarmante, Celso de Mello fazer uma bela defesa do que norteia o direito ao meio ambiente ecologicamente equilibrado e terminar com a defesa de uma anistia tão extensa, que viola o núcleo essencial de tal direito fundamental e o princípio da proporcionalidade. A constitucionalidade da anistia não foi consenso entre os ministros ${ }^{165}$, o que fica claro, por exemplo, no voto de Luix Fux e no seguinte entendimento vencido de Luís Roberto Barroso no Plenário do STF:

Como regra geral, não há inconstitucionalidade na opção legislativa pela suspensão ou extinção da responsabilidade administrativa, civil ou criminal imposta em

\footnotetext{
${ }^{164}$ STF, ADIs n. 4901, 4902, 4903, 4937 e ADC n. 42, Rel. Ministro Luiz Fux, Brasília. Julgamento conjunto no Plenário do STF concluído em 28 fev. 2018.

${ }_{165}$ Posicionaram-se pela constitucionalidade da anistia a Presidente Cármen Lúcia, Dias Toffoli, Gilmar Mendes, Alexandre de Moraes e Celso de Mello; já o Min. Relator Luiz Fux, Marco Aurélio, Rosa Weber, Edson Fachin e Luís Roberto Barroso consideraram inconstitucional a anistia "e não perceberam lógica razoável para a fixação do marco temporal de 2008". Conforme registrado em notícia veiculada pela Terra de Direitos (organização de Direitos Humanos): BITTENCOURT, Naiara Andreoli. Com apenas um voto pendente, julgamento do Código Florestal será finalizado na próxima quarta, dia 28. Disponível em http://terradedireitos.org.br/noticias/noticias/com-apenasum-voto-pendente-julgamento-do-codigo-florestal-sera-finalizado-na-proxima-quartafeira-dia$\underline{28 / 22736}$ Acesso em 2 jun. 2018.
} 
virtude de atos lesivos ao meio ambiente. [...] O limite da intervenção é a inconstitucionalidade ou não. A significativa atenuação do dever de reparação ao meio ambiente, com a definição de regime jurídico mais favorável para aqueles que desmataram Áreas de Preservação Permanente e de Reserva Legal anteriormente a 22 de julho de 2008 [...] viola o princípio da proporcionalidade, tanto na dimensão da proteção deficiente, quanto na proporcionalidade em sentido estrito, porque impõe severos ônus ao meio ambiente, mas gera benefícios ínfimos em razão da estabilização de situações jurídicas consolidadas. ${ }^{166}$ (Grifos meus)

Com o resultado do julgamento das ações sobre o Código Florestal no STF, o Legislativo, Executivo e Judiciário falharam em cumprir as obrigações do Poder Público para garantir o direito ao meio ambiente ecologicamente equilibrado. O STF não estaria usurpando a competência do Legislativo ao declarar a inconstitucionalidade do Código Florestal de 2012, visto que é obrigação do Poder Judiciário cumprir as previsões do Art. 225, $\S 1^{\circ} \mathrm{CF} / 88$ e fazer o controle abstrato de constitucionalidade ${ }^{167}$ das normas em face da Constituição Federal ${ }^{168}$. A Lei 12.651/2012, ao permitir a alteração, utilização e supressão de APP e RL que compromete a integridade dos atributos que justificam a sua proteção ${ }^{169}$, é notoriamente contrária ao Art. 225 da Constituição e os princípios norteadores do Direito Ambiental, previstos no mesmo dispositivo, de forma implícita ou explícita.

A aprovação do Código Florestal de 2012 não foi uma conciliação de interesses, e é mais um exemplo de uma preocupante investida do Legislativo nacional pela desconstrução da legislação ambiental: recentemente o Congresso Nacional tem tentado, sucessivas vezes, flexibilizar e até descaracterizar o licenciamento ambiental e o Estudo de Impacto Ambiental, concretização dos princípios da precaução e prevenção (Art. 225, § $1^{\circ}$, IV e V, CF/88); em 2018, lutam pelo fim da obrigatoriedade do selo dos transgênicos ${ }^{170}$, em notória contramão em relação aos princípios da

\footnotetext{
${ }^{166}$ STF, ADIs n. 4901, 4902, 4903, 4937 e ADC n. 42, Rel. Ministro Luiz Fux, Brasília. Julgamento conjunto no Plenário do STF concluído em 28 fev. 2018.

${ }^{167} \mathrm{O}$ controle concentrado de constitucionalidade consiste na atribuição da guarda da Constituição a um único órgão ou número limitado deles. Barroso

${ }^{168}$ BARROSO, Luís Roberto. O controle de constitucionalidade no direito brasileiro: exposição sistemática da doutrina e análise crítica da jurisprudência. $6^{a}$ ed..São Paulo: Saraiva, 2012. p. 183 ${ }^{169}$ Art. 225, § 1º III. Constituição da República Federativa do Brasil de 1988.

${ }^{170}$ A exemplo do que pode ser lido em: AGÊNCIA SENADO. Comissão de Meio Ambiente aprova fim de selo de identificação de produtos com transgênicos. Disponível em
} 
precaução, prevenção e vedação ao retrocesso ${ }^{171}$. Guilherme Purvin de Figueiredo, Coordenador Geral da APRODAB, chama atenção para o retrocesso mais direto:

Em 2017, para contornar a proibição da vaquejada, pela primeira vez desde a sua promulgação, a Constituição de 1988 sofreu uma alteração prejudicial à proteção do meio ambiente, com a introdução de um $\S 7^{\circ}$ ao Art. 225 que, resumo, afirma que tratamentos cruéis contra animais não são cruéis se forem "manifestações culturais" e se houver lei assegurando o bem-estar dos animais submetidos a crueldade. ${ }^{172}$

O prevalecimento quase total dos interesses da bancada ruralista em julgamento tão importante no STF para o Direito Ambiental colabora para a perigosa tendência de desconstrução do que havia sido conquistado, criando inclusive um "direito adquirido de persistir na prática delituosa"173. A luta passa a não ser apenas por novos avanços, mas também pela proteção do que permanece vigente.

https://www12.senado.leg.br/noticias/materias/2018/04/17/comissao-de-meio-ambiente-aprovafim-de-selo-identificacao-de-produtos-com-transgenicos Acesso em 2 jun. 2018.

${ }^{171}$ Há inclusive clara violação ao direito constitucional de proteção ao consumidor e aos direitos do consumidor (ver Lei 8.078/1990), como a garantia de informação adequada e clara sobre os diferentes produtos (Art. $6^{\circ}$, III, Lei 8.078/1990).

${ }^{172}$ FIGUEIREDO, Guilherme José Purvin de. Estado de Exceção Ambiental. Disponível em $<$ http://www.oeco.org.br/colunas/guilherme-jose-purvin-de-figueiredo/estado-de-excecaoambiental/> Acesso em 2 jun. 2018.

${ }^{173}$ FIGUEIREDO, Guilherme José Purvin de. Estado de Exceção Ambiental. Disponível em $<\mathrm{http}: / /$ www.oeco.org.br/colunas/guilherme-jose-purvin-de-figueiredo/estado-de-excecaoambiental/> Acesso em 2 jun. 2018. 2 jun. 2018. 


\section{CONCLUSÃO}

A Lei 12.651/2012, como demonstrado, caminha na direção oposta do constante aumento da proteção ambiental que vinha ocorrendo desde a ecologização da sociedade. Com a constitucionalização do direito ao meio ambiente ecologicamente equilibrado, o ordenamento jurídico brasileiro seguia cada vez mais rumo à concretização de tal direito, o que é possível com a observância dos princípios norteadores do Direito Ambiental. Havia muita expectativa e esperança em torno do julgamento conjunto das ADIs 4901, 4902, 4903, 4937 e ADC 42, que julgariam uma lei que claramente estabelece uma proteção ambiental muito inferior à do Código Florestal de 1965, além de proporcionar uma extensa anistia a quem desmatou ilegalmente em desacordo com os padrões anteriores antes de 22 de julho 2008.

O Direito Ambiental brasileiro vinha sendo construído em uma reta ascendente, rumo à uma garantia cada vez maior das previsões do Art. 225 da Constituição Federal acerca do direito fundamental ao meio ambiente ecologicamente equilibrado e os deveres do Poder Público e da coletividade para garanti-lo. Demostrou-se neste trabalho que os princípios norteadores do Direito Ambiental estabelecem um caminhar constante em direção à maior proteção, sempre observando a adoção de medidas de prevenção e precaução diante de impactos conhecidos e ainda desconhecidos pela ciência.

Quando finalmente estava havendo maior implementação da avançada legislação brasileira, a bancada ruralista começou uma série de ataques para desconstruir o que outrora se tinha.

Demonstrou-se neste trabalho que o Código Florestal de 2012, fruto de um controverso processo legislativo, é um exemplo notório desses ataques. Isso ficou claro pelos exemplos da diminuição da proteção de APP e RL, sobretudo com os dados mencionados e os artigos diretamente contrários aos alertas e recomendações da comunidade científica, a exemplo 
da medição de APP a partir do leito regular dos cursos d'água e consolidação de atividades agrossilvipastoris anteriores a 22 de julho de 2008 em encostas e morros.

Apesar dos votos dos ministros do STF mencionarem e reconhecem a importância dos princípios norteadores do Direito Ambiental brasileiro para uma maior proteção do direito ao meio ambiente ecologicamente equilibrado, o que é fundamental para assegurar sua observância na jurisprudência de todas as instâncias do Judiciário, o resultado do julgamento colabora para uma perigosa e preocupante tendência. Prevaleceu a tese de que o processo legislativo que originou o Código Florestal de 2012, em nome do princípio democrático e respeito às decisões do Poder Legislativo, deveria prevalecer sobre o princípio da vedação ao retrocesso, pois o núcleo essencial do direito ao meio ambiente ecologicamente equilibrado não teria sido atingido. Desse modo, o direito ao meio ambiente ecologicamente equilibrado e sua proteção que permeia todo o ordenamento jurídico, junto com os princípios norteadores do Direito Ambiental e os diversos alertas da comunidade científica, não prevaleceram.

Diante das constantes tentativas de desconstruir a proteção ambiental então alcançada, a exemplo dos recentes projetos de lei que visam descaracterizar o licenciamento ambiental e os estudos de impacto ambiental, é preocupante o STF ter declarado a constitucionalidade de tantos artigos da Lei 12.651/2012, com fundamento no respeito às decisões do Legislativo. A harmonia entre os três poderes, Executivo, Legislativo e Judiciário, é fundamental. Entretanto, é dever do STF declarar a inconstitucionalidade, quando provocado, de legislação contrária à Constituição Federal. A lei 12.651/2012, como demonstrou-se neste trabalho, viola os deveres do Poder Público para assegurar o direito ao meio ambiente ecologicamente equilibrado, visto que a alteração e supressão de espaços territorialmente protegidos é vedada quando comprometer os atributos que justifiquem a sua proteção (Art. 225, § 1º III, da Constituição Federal de 1988). 
Como foi mencionado, não há uma crise agrícola que justifique as controversas escolhas do Congresso nacional e tantos retrocessos instaurados por uma única lei. O Brasil pode e deve seguir o exemplo de algumas economias emergentes para aumentar muito mais o PIB sem depender do agronegócio: o investimento em ciência e tecnologia, incluindo a biotecnologia, que pode alavancar astronomicamente o PIB em um país tão rico em biodiversidade como o Brasil.

A própria solução para o aumento da produtividade agrícola sem degradar o meio ambiente está na tecnologia e Educação. Um uso cientificamente planejado do solo não esgota sua fertilidade tão rápido como vem acontecendo atualmente, e o emprego de tecnologia aumenta a produtividade sem necessitar expandir determinada área.

O Poder Público precisa se desvincular do passado, da influência de uma oligarquia secular que tenta desmantelar a legislação ambiental e trabalhista. Tal grupo tentou diminuir e flexibilizar inclusive a definição de "trabalho análogo à escravidão". O cerceamento da liberdade e dignidade da pessoa humana ainda é encontrado em muitas propriedades rurais, incluindo de membros da bancada ruralista, o que não se pretende expor neste trabalho.

O Supremo Tribunal Federal criou um precedente potencialmente perigoso, mas as novas gerações de cientistas, juristas e ambientalistas estão cada vez mais instruídas. Segue a luta. 


\section{REFERÊNCIAS BIBLIOGRÁFICAS}

FRANCISCO I. Laudato Si: Carta Encíclica sobre o cuidado da casa comum. Disponível em

$<$ http://w2.vatican.va/content/francesco/pt/encyclicals/documents/papafrancesco_20150524_enciclica-laudato-si.html> Acesso em 2 jun. 2018.

ARAGÃO, Maria Alexandra. O princípio do poluidor-pagador: pedra angular da política comunitária do ambiente. São Paulo: Inst. O Direito por um Planeta Verde, 2014. 319 p.

CARRINGTON, Damian. The Anthropocene epoch: scientists declare dawn of human-influenced age. Disponível em $<$ https://www.theguardian.com/environment/2016/aug/29/declareanthropocene-epoch-experts-urge-geological-congress-human-impactearth>. Acesso em 2 jun. 2018.

MILARÉ, Édis. Direito do Ambiente. $8^{\mathrm{a}}$ ed.. São Paulo: Revista dos Tribunais, 2013. 1614 p.

MACHADO, Paulo Affonso Leme. Direito Ambiental Brasileiro.22 ${ }^{\mathrm{a}}$ ed.. São Paulo: Malheiros, 2014. 1344 p.

$<$ http://www.senado.gov.br/noticias/Jornal/emdiscussao/rio20/temasem-discussao-na-rio20/ecodesenvolvimento-conceito-desenvolvimentosustentavel-relatorio-brundtland-onu-crescimento-economico-pobrezaconsumo-energia-recursos-ambientais-poluicao.aspx > Acesso 2 jun. 2018. 
BENJAMIN, Antonio Herman. Constitucionalização do Ambiente e Ecologização da Constituição Brasileira. In: CANOTILHO, José Joaquim Gomes; LEITE, José Rubens Morato (Org.). Direito Constitucional Ambiental Brasileiro. São Paulo: Saraiva, 2007. p. 57 - 135.

SILVA, José Afonso da. Curso de Direito Constitucional Positivo. $37^{\mathrm{a}}$ ed.. São Paulo: Malheiros, 2014. 934 p.

ANTUNES, Paulo de Bessa. Direito Ambiental. 16ª ed.. São Paulo: Atlas, 2014. $1420 \mathrm{p}$.

Declaração do Rio sobre Meio Ambiente e Desenvolvimento. Disponível em 〈http://www.onu.org.br/rio20/img/2012/01/rio92.pdf> Acesso em 2 jun. 2018.

MOREIRA, Danielle de Andrade. Responsabilidade ambiental pósconsumo: prevenção e reparação de danos à luz do princípio do poluidorpagador. São Paulo: Letras Jurídicas; Rio de Janeiro: Ed. PUC-Rio, 2015. $390 \mathrm{p}$.

PIEUR, Michel. O princípio da proibição de retrocesso ambiental. In: Senado Federal. Princípio da Proibição de Retrocesso Ambiental. Brasília: Senado Federal, 2012. p. 11 - 54. Disponível em http://www2.senado.gov.br/bdsf/handle/id/242559 Acesso em 2 jun. 2018.

BENJAMIN, Herman. O princípio da proibição de retrocesso ambiental. In: Senado Federal. Princípio da Proibição de Retrocesso 
Ambiental. Brasília: Senado Federal, 2012. p. 55 - 72. Disponível em http://www2.senado.gov.br/bdsf/handle/id/242559 Acesso em 2 jun. 2018.

MOLINARO, Carlos Alberto. Interdição da retrogradação ambiental - Reflexões sobre um princípio. In: Senado Federal. Princípio da Proibição de Retrocesso Ambiental. Brasília: Senado Federal, 2012. p. 73 - 120. Disponível em http://www2.senado.gov.br/bdsf/handle/id/242559 Acesso em 2 jun. 2018.

SARLET, Ingo Wolfgang; FENSTERSEIFER, Tiago. Código Florestal: 45 anos: estudos e reflexoes / Guilherme José Purvin de Figueiredo, Lindamar Monteiro da Silva, Marcelo abelha Rodrigues e Márcia Dieguez Leuzinger (organizadores). Curitiba: Letra da Lei, 2010. p. 31-62.

SARLET, Ingo Wolfgang; FENSTERSEIFER, Tiago. Notas sobre a proibição de retrocesso em matéria (sócio)ambiental. In: Senado Federal. Princípio da Proibição de Retrocesso Ambiental. Brasília: Senado Federal, 2012. $\quad$ p. $\quad 121 \quad-\quad$ 206. $\quad 2$ Disponível em http://www2.senado.gov.br/bdsf/handle/id/242559 Acesso em 2 jun. 2018.

1 LIMA, Letícia Maria Rêgo Teixeira. O novo Código Florestal (LEI 12.651/2012) à luz do princípio da vedação ao retrocesso socioambiental. Trabalho de Conclusão de Curso - Faculdade de Direito, Pontifícia Universidade Católica do Rio de Janeiro, Rio de Janeiro. 2015. Disponível em https://www.maxwell.vrac.puc-rio.br/26087/26087.PDF. Acesso em 2 jun. 2018.

FIGUEIREDO, Guilherme José Purvin de; LEUZINGER, Márcia Dieguez. Anotações atualizadas acerca do Processo Legislativo de Reforma do Código Florestal. In: FIGUEIREDO, Guilherme José Purvin et al (Org.). 
Código Florestal:45 anos: estudos e reflexões. Curitiba: Letra da Lei; São Paulo: IBAP, 2010. p. 17-30.

PITTA, Fábio Teixeira et al.. Impactos da expansão do agronegócio no MATOPIBA: comunidade e meio ambiente. Disponível em $<$ http://semcerrado.org.br/wpcontent/uploads/2017/09/1505227050ACTIONAID_MATOPIBA_PORT_ WEB_05SET.pdf> Acesso em 2 jun. 2018. 2 jun. 2018.

TAVARES, Vinícius. Meio Ambiente debate os impactos do avanço da fronteira agrícola no bioma Cerrado. Disponível em $<$ http://www.olhardireto.com.br/agro/noticias/exibir.asp?id=14533\&noticia =meio-ambiente-debate-os-impactos-do-avanco-da-fronteira-agricola-nobioma-cerrado> Acesso em 2 jun. 2018.

IBAMA; GeoBrasil 2002. Perspectivas do Meio Ambiente no Brasil. Brasília: Edições IBAMA, 2002. Disponível em http://www.ibama.gov.br/sophia/cnia/site_cnia/geo_brasil_2002.pdf Acesso em 2 jun. 2018. 2 jun. 2018.

SOUZA, Oswaldo Braga de. Desmatamento na Amazônia explode entre 2015 e 2016. Disponível em https://www.socioambiental.org/pt-br/noticias$\underline{\text { socioambientais/desmatamento-na-amazonia-explode-entre-2015-e-2016 }}$ Acesso em 2 jun. 2018.

$<$ http://www.inpe.br/noticias/noticia.php?Cod_Noticia=4344 $>$ Acesso em 2 jun. 2018.

FELLET, João. Maior lobby no Congresso, ruralistas controlam 1/4 da Câmara. 
<http://www.bbc.com/portuguese/noticias/2012/05/120524_ruralistas_abre jjf> Acesso em 2 jun. 2018. 2 jun. 2018.

CAMARGO, Renata. Ruralistas avançam sobre o meio ambiente no Congresso. Disponível em $<$ http://congressoemfoco.uol.com.br/noticias/ruralistas-avancam-sobre-omeio-ambiente-no-congresso/> Acesso em 2 jun. 2018. 2 jun. 2018.

FIGUEIREDO, Guilherme José Purvin de. Comentários ao Art. $1^{\circ}$ da Lei 12.651, de 25 de maio de 2012. In: MILARÉ, Édis; MACHADO, Paulo Affonso Leme (Org.). Novo Código Florestal: Comentários à Lei 12.651, de 25 de maio de 2012, à Lei 12.727, de 17 de outubro de 2012 e ao Decreto 7.830, de 17 de outubro de2012. $2^{\text {a }}$ ed. São Paulo: Revista dos Tribunais, 2013. p. 30-39.

GUIMARÃES, Virgínia Totti. A (in)constitucionalidade do Novo Código Florestal no STF e o voto de Luix Fux. Disponível em http://justificando.cartacapital.com.br/2017/12/05/inconstitucionalidade-donovo-codigo-florestal-no-stf-e-o-voto-de-luiz-fux/ Acesso em 2 jun. 2018.

FIGUEIREDO, Guilherme José Purvin de. Estado de Exceção Ambiental. Disponível em <http://www.oeco.org.br/colunas/guilherme-josepurvin-de-figueiredo/estado-de-excecao-ambiental/> Acesso em 2 jun. 2018.

ORENSTEIN, José. O que mudou depois de 5 anos da sanção do Novo Código Florestal. Disponível em <https://www.nexojornal.com.br/expresso/2017/05/25/O-que-mudoudepois-de-5-anos-da-san\%C3\%A7\%C3\%A3o-do-Novo-C\%C3\%B3digoFlorestal> Acesso em 2 jun. 2018. 
GUIDOTTI, Vinicius et al.. Números detalhados do Novo Código Florestal e suas implicações para os PRAs: Sustentabilidade em debate, Número 5. SP: Imaflora, 2017. Disponível em <http://www.imaflora.org/downloads/biblioteca/5925cada05b49_SUSTem DEB_low_web_links.pdf> Acesso em 2 jun. 2018. 10 p.

SILVA, José Antonio Aleixo da et al.. O Código Florestal e a Ciência: Contribuições para o Diálogo. São Paulo: Sociedade Brasileira para o Progresso da Ciência, SBPC; Academia Brasileira de Ciências, ABC, 2011. $93 \mathrm{p}$.

<https://www.embrapa.br/codigo-florestal/area-de-reserva-legalarl/modulo-fiscal> Acesso em 2 jun. 2018.

CANEJO, Andressa. $\mathrm{N}^{\mathrm{o}}$ de vítimas em tragédia no RJ pode ser 10 vezes maior, diz entidade. Disponível em http://g1.globo.com/rj/regiaoserrana/noticia/2015/08/entidades-apontam-subnotificacao-de-vitimas-datragedia-de-2011-na-serra.html Acesso em 2 jun. 2018.

SCHÄFFER, Wigold Bertoldo et al.. Áreas de Preservação Permanente e Unidades de Conservação \& Áreas de Risco: O que uma coisa tem a ver com a outra? Relatório de Inspeção da área atingida pela tragédia das chuvas na Região Serrana do Rio de Janeiro. Brasília: MMA, 2011. Disponível em <http://www.mma.gov.br/estruturas/202/_publicacao/202_publicacao01082 011112029.pdf> Acesso em 2 jun. 2018.99 p.

LOPES, Juliana Chermont Pessoa. Os pagamentos por serviços ambientais e a cota de reserva ambiental no Código Florestal de 2012. Trabalho de Conclusão de Curso - Faculdade de Direito, Pontifícia Universidade Católica do Rio de Janeiro, Rio de Janeiro. 2017. Disponível 
em https://www.maxwell.vrac.puc-rio.br/31432/31432.PDF Acesso em 2 jun. 2018

MORAIS, Roberta Jardim de; GUETTA, Maurício. Comentários à Cota de Reserva Ambiental. In: MILARÉ, Édis; MACHADO, Paulo Affonso Leme (Org.). Novo Código Florestal: Comentários à Lei 12.651, de 25 de maio de 2012, à Lei 12.727, de 17 de outubro de 2012 e ao Decreto 7.830, de 17 de outubro de2012. $2^{\text {a }}$ ed. São Paulo: Revista dos Tribunais, 2013. p. 359 -372 .

CHIAVARI, Joana; LOPES, Cristina Leme. Decisão do STF sobre o Novo Código Florestal enfraquece a Cota de Reserva Ambiental. Disponível em <http://www.oeco.org.br/colunas/colunistas-convidados/decisao-do-stfsobre-o-novo-codigo-florestal-enfraquece-a-cota-de-reserva-ambiental/> Acesso em 2 jun. 2018.

SOUZA, Oswaldo Braga. Relator rejeita a anistia a multas ambientais em julgamento do Código Florestal no STF. Disponível em https://www.socioambiental.org/pt-br/noticias-socioambientais/relatorrejeita-anistia-a-multas-ambientais-em-julgamento-do-codigo-florestal-no-

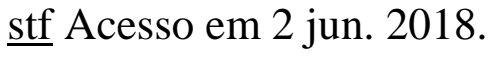

CHIAVARI, Joana; LOPES, Cristina Leme. Nota Técnica: Comentários ao voto do Ministro Luiz Fux, ADIs em face da Lei $\mathrm{N}^{\circ}$ 12.651/2012 (Novo Código Florestal). Iniciativa para o Uso da Terra (Input) / Climate Policy Initiative, 2017. Disponível em $<$ https://climatepolicyinitiative.org/wpcontent/uploads/2017/11/Nota_Tecnica_ADIs_Codigo_Florestal_Comentar ios_ao_voto_do_Ministro_Luis_Fux.pdf.> Acesso em 2 jun. 2018. 14 p. 
INSTITUTO SOCIOAMBIENTAL. Julgamento do Código Florestal no STF: os riscos para o Cerrado e o abastecimento de água. Disponível em< https://www.socioambiental.org/pt-br/noticias-socioambientais/julgamentodo-codigo-florestal-no-stf-os-riscos-para-o-cerrado-e-o-abastecimento-deagua $>$ Acesso em 2 jun. 2018.

INSTITUTO SOCIOAMBIENTAL. Julgamento do Código Florestal no STF. Disponível em: https://www.socioambiental.org/sites/blog.socioambiental.org/files/nsa/arqu ivos/tabela_voto_luiz_fux___codigo_florestal.pdf Acesso em 2 jun. 2018

BITTENCOURT, Naiara Andreoli. Placar do julgamento do Código Florestal no STF - Lei 12.651/2012 (ADIS 4901, 4902, 4903, 4937 e ADC 42). Disponível em http://terradedireitos.org.br/uploads/arquivos/QuadroADIs-Codigo-Florestal-final.pdf Acesso em 2 jun. 2018.

TEIXEIRA, Matheus; CARNEIRO, Luiz Orlando. STF valida quase todo Código Florestal e desagrada ambientalistas. Disponível em https://www.jota.info/stf/stf-valida-quase-todo-codigo-florestal-edesagrada-ambientalistas-28022018 Acesso em 2 jun. 2018.

BITTENCOURT, Naiara Andreoli. Com apenas um voto pendente, julgamento do Código Florestal será finalizado na próxima quarta, dia 28. Disponível em http://terradedireitos.org.br/noticias/noticias/com-apenas$\underline{\text { um-voto-pendente-julgamento-do-codigo-florestal-sera-finalizado-na- }}$ proxima-quartafeira-dia-28/22736 Acesso em 2 jun. 2018.

BARROSO, Luís Roberto. O controle de constitucionalidade no direito brasileiro: exposição sistemática da doutrina e análise crítica da jurisprudência. $6^{\text {a }}$ ed..São Paulo: Saraiva, 2012. 452 p. 
AGÊNCIA SENADO. Comissão de Meio Ambiente aprova fim de selo de identificação de produtos com transgênicos. Disponível em https://www12.senado.leg.br/noticias/materias/2018/04/17/comissao-de$\underline{\text { meio-ambiente-aprova-fim-de-selo-identificacao-de-produtos-com- }}$ transgenicos Acesso em 2 jun. 2018.

Jurisprudência:

STF, MS n. 22164-0-SP, Rel. Ministro Celso de Mello, Brasília, 30 out. 1995 .

STF, RE n. 627189, Rel. Ministro Dias Toffoli, Brasília, 06 jun. 2016.

STF, ADIs n. 4901, 4902, 4903, 4937 e ADC n. 42, Rel. Ministro Luiz Fux, Brasília. Julgamento conjunto no Plenário concluído em 28 fev. 2018.

STF, ADI n. 4901, Rel. Ministro Luiz Fux, Brasília. Julgamento conjunto no Plenário do STF, concluído em 28 fev. 2018. Petição Inicial ajuizada pelo Ministério Público Federal, em 18 jan. 2013.

STF, ADI n. 4902, Rel. Ministro Luiz Fux, Brasília. Julgamento conjunto em Plenário, concluído em 28 fev. 2018. Petição Inicial ajuizada pelo Ministério Público Federal, em jan. 2013

STJ, Resp n. 302.906/SP, Rel. Ministro Herman Benjamin, Brasília, 26 ago. 2010. 
